Prepared in cooperation with the North Platte Natural Resources District, the South Platte Natural Resources District, and the Nebraska Environmental Trust

\title{
Airborne Electromagnetic Mapping of the Base of Aquifer in Areas of Western Nebraska
}

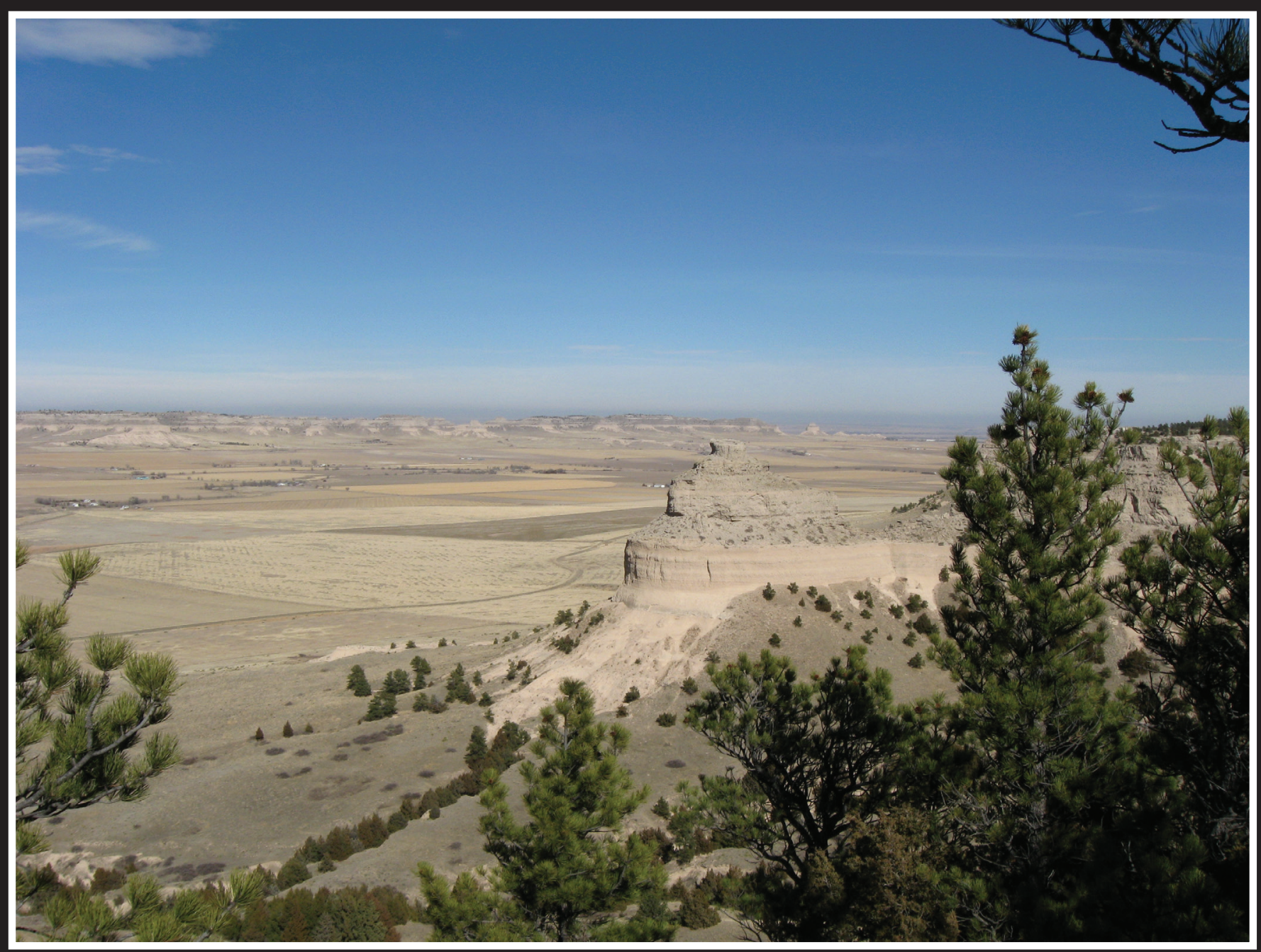

Scientific Investigations Report 2011-5219

U.S. Department of the Interior

U.S. Geological Survey 
COVER: Cedar Canyon Wildlife Management Area, southwest of Scottsbluff, Nebr., March 2011. Photograph by Christopher M. Hobza, U.S. Geological Survey Nebraska Water Science Center. The view is to the north across Gering Valley toward Scotts Bluff National Monument. 


\section{Airborne Electromagnetic Mapping of the Base of Aquifer in Areas of Western Nebraska}

By Jared D. Abraham, James C. Cannia, Paul A. Bedrosian, Michaela R. Johnson, Lyndsay B. Ball, and Steven S. Sibray

Prepared in cooperation with the North Platte Natural Resources District, the South Platte Natural Resources District, and the Nebraska Environmental Trust

Scientific Investigations Report 2011-5219 


\title{
U.S. Department of the Interior \\ KEN SALAZAR, Secretary \\ U.S. Geological Survey \\ Marcia K. McNutt, Director
}

\author{
U.S. Geological Survey, Reston, Virginia: 2012
}

For more information on the USGS - the Federal source for science about the Earth, its natural and living resources, natural hazards, and the environment, visit http://www.usgs.gov or call 1-888-ASK-USGS.

For an overview of USGS information products, including maps, imagery, and publications, visit http://www.usgs.gov/pubprod

To order this and other USGS information products, visit http://store.usgs.gov

Any use of trade, product, or firm names is for descriptive purposes only and does not imply endorsement by the U.S. Government.

Although this report is in the public domain, permission must be secured from the individual copyright owners to reproduce any copyrighted materials contained within this report.

Suggested citation:

Abraham, J.D., Cannia, J.C., Bedrosian, P.A., Johnson, M.R., Ball, L.B., Sibray, S.S., 2012, Airborne electromagnetic mapping of the base of aquifer in areas of western Nebraska: U.S. Geological Survey Scientific Investigations Report 2011-5219, 38 p. 


\section{Contents}

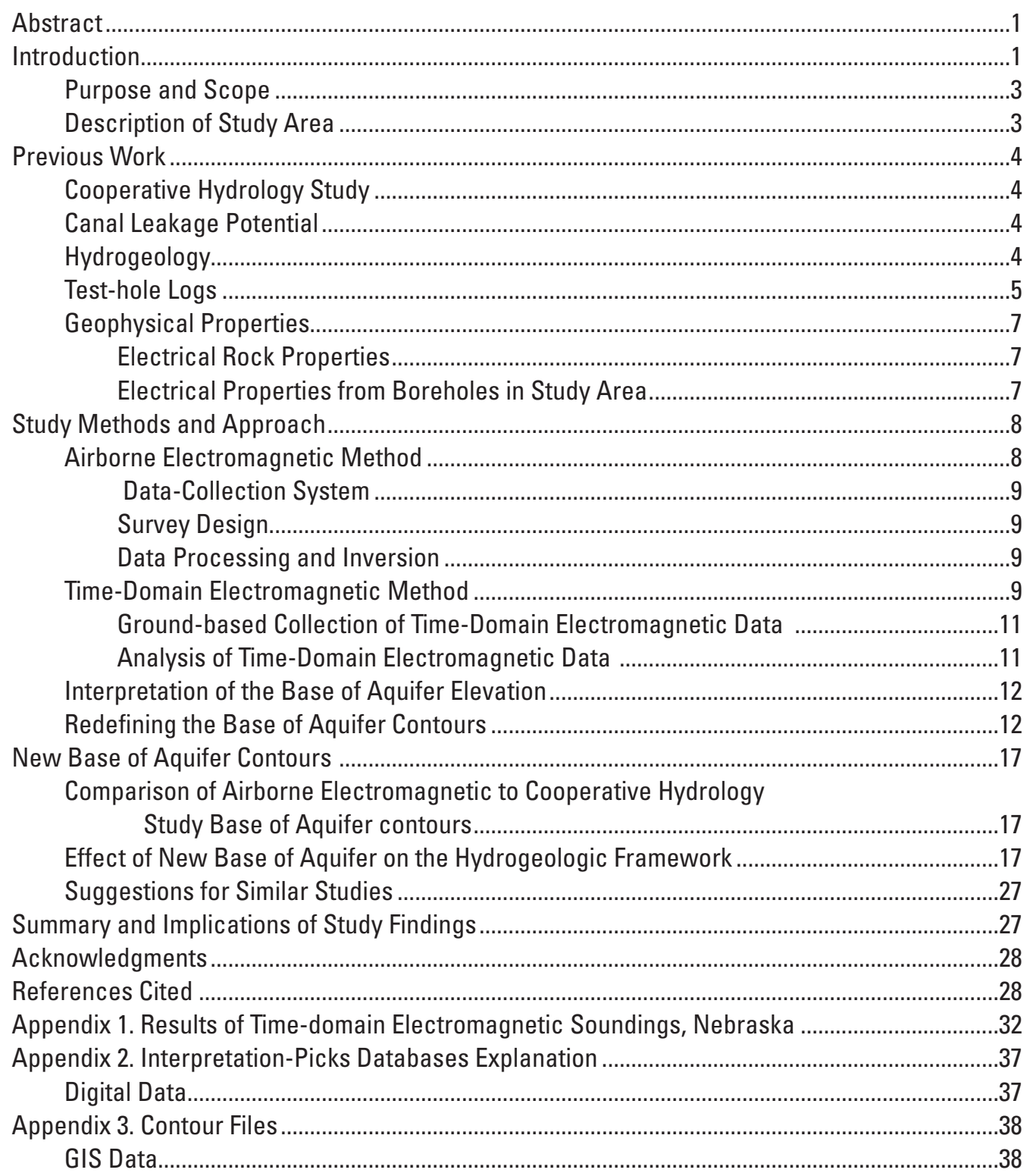

\section{Figures}

1. Map showing the location of the geophysical survey areas within the North and South Platte Natural Resources Districts (NPNRD and SPNRD, respectively), Nebraska, relative to existing hydrologic studies of the Platte River Basin......................2

2. Map showing locations of geophysical data collection within the North and South Platte Natural Resource Districts (NPNRD and SPNRD, respectively), Nebraska

3. Block diagram showing Cooperative Hydrology Study (COHYST) hydrostratigraphic units in the study area, Nebraska.

4. Examples of inverted airborne electromagnetic (AEM) profiles showing the depth-of-investigation metric . 
5. Two-dimensional graph showing an inverted airborne electromagnetic section from 2008 flight line 30030 in the North Platte Natural Resources District (NPNRD), Nebr., with complementary datasets

6. Two-dimensional graph showing an inverted airborne electromagnetic section from 2008 flight line 40070 in the South Platte Natural Resources District (SPNRD), Nebr., with complementary datasets

7. Three-dimensional fence diagram showing inverted time-domain electromagnetic soundings and airborne electromagnetic sections from flights of the North Platte Natural Resources District, Nebr., 2008

8. Maps of $(A)$ North and $(B)$ South Platte Natural Resource Districts, Nebr., showing the depth-to-bedrock picks from the helicopter electromagnetic inversions and the confidence metric for the picks.

9. Examples of the new base of aquifer contours within the North Platte Natural Resources District, Nebr.

10. Examples of new base of aquifer $(B O A)$ contours within the South Platte Natural Resources District.

11. Hydrogeologic cross sections showing the new base of aquifer, Cooperative Hydrology Study base of aquifer, and the 1995 Cooperative Hydrology Study base of aquifer water table for $(A)$ a N-S profile east of Bridgeport, Nebr., across the North Platte River; and $(B)$ a NE-SW profile north of Sidney, Nebr.

12. Map of thickness changes of the primary aquifer within the North Platte Natural Resources District, Nebr., between the new base of aquifer and the Cooperative Hydrology Study base of aquifer

13. Contoured map showing details of the thickness change of the primary aquifer for selected areas in the North Platte Natural Resources District, Nebr., between the new base of aquifer and the Cooperative Hydrology Study base of aquifer

14. Map of thickness changes of the primary aquifer within the South Platte Natural Resources District, Nebr., between the new base of aquifer and the Cooperative Hydrology Study base of aquifer.

15. Contoured map showing details of the thickness changes of the primary aquifer for selected areas in the South Platte Natural Resources District between the new base of aquifer and the Cooperative Hydrology Study base of aquifer, Nebr

16. Contoured map showing saturated thickness calculated from the 1995 Cooperative Hydrology Study water table using $(A)$ the new base of aquifer, and $(B)$ the Cooperative Hydrology Study base of aquifer for the North Platte Natural Resources District, Nebr.

17. Contoured map showing saturated thickness calculated from the 1995

Cooperative Hydrology Study water table using $(A)$ the new base of aquifer, and $(B)$ the Cooperative Hydrology Study base of aquifer for the South Platte Natural Resources District, Nebr.

\section{Tables}

1. Principal hydrogeologic units of the Cooperative Hydrology Study (COHYST) Western Groundwater Model area, Nebraska...

2. Station coordinates and elevations for ground-based time-domain electromagnetic (TDEM) soundings, North and South Platte Natural Resources Districts, Nebr. 


\section{Conversion Factors, Datum, Units, and Abbreviations}

SI to Inch/Pound

\begin{tabular}{|c|c|c|}
\hline Multiply & By & To obtain \\
\hline \multicolumn{3}{|c|}{ Length } \\
\hline meter $(\mathrm{m})$ & 3.281 & foot $(\mathrm{ft})$ \\
\hline kilometer (km) & 0.6214 & mile (mi) \\
\hline \multicolumn{3}{|c|}{ Area } \\
\hline square meter $\left(\mathrm{m}^{2}\right)$ & 0.0002471 & acre \\
\hline hectare (ha) & 2.471 & acre \\
\hline \multicolumn{3}{|c|}{ Volume } \\
\hline cubic meter $\left(\mathrm{m}^{3}\right)$ & 0.00081 & acre-foot \\
\hline
\end{tabular}

Temperature in degrees Celsius $\left({ }^{\circ} \mathrm{C}\right)$ may be converted to degrees Fahrenheit $\left({ }^{\circ} \mathrm{F}\right)$ as follows:

$$
{ }^{\circ} \mathrm{F}=\left(1.8 x^{\circ} \mathrm{C}\right)+32
$$

Temperature in degrees Fahrenheit $\left({ }^{\circ} \mathrm{F}\right)$ may be converted to degrees Celsius $\left({ }^{\circ} \mathrm{C}\right)$ as follows:

$$
{ }^{\circ} \mathrm{C}=\left({ }^{\circ} \mathrm{F}-32\right) / 1.8
$$

\section{Datum information used in this report}

Vertical coordinate information is referenced to the National Geodetic Vertical Datum of 1929 (NGVD29).

Horizontal coordinate information is referenced to the North American Datum of 1983 (NAD 83).

Elevation, as used in this report, refers to distance above the vertical datum.

\section{Abbreviations used in this report}

$\begin{array}{ll}\mathrm{cm} & \text { centimeter } \\ \mathrm{ft} & \text { feet } \\ \mathrm{ha} & \text { hectare } \\ \text { in } & \text { inch } \\ \mathrm{km} & \text { kilometer } \\ \mathrm{km}^{2} & \text { square kilometer } \\ \mathrm{mi} & \text { mile } \\ \mathrm{m} & \text { meter } \\ \mathrm{m}^{2} & \text { square meter } \\ \mathrm{m}^{3} & \text { cubic meter } \\ \mathrm{Ma} & \text { age, before present, in millions of years } \\ \text { ohm-m } & \text { ohm meter }{ }^{2} \text { per meter mathematically reduced to ohm-meter }\end{array}$

\section{Abbreviated terms used in this report}

$\begin{array}{ll}\text { 2-D } & \text { two-dimensional } \\ \text { 3-D } & \text { three-dimensional } \\ \text { AEM } & \text { airborne electromagnetic } \\ \text { BOA } & \text { base of aquifer } \\ \text { COHYST } & \text { Cooperative Hydrology Study } \\ \text { CSD } & \text { Conservation and Survey Division } \\ \text { DEM } & \text { digital elevation model } \\ \text { DOI } & \text { depth of investigation } \\ \text { EM } & \text { electromagnetic } \\ \text { GIS } & \text { Geographical Information System } \\ \text { HEM } & \text { Helicopter Electromagnetic } \\ \text { NDNR } & \text { Nebraska Department of Natural Resources } \\ \text { NED } & \text { National Elevation Dataset } \\ \text { NPNRD } & \text { North Platte Natural Resources District } \\ \text { NRD } & \text { Natural Resources District } \\ \text { PRRIP } & \text { Platte River Recovery and Implementation Program } \\ \text { SPNRD } & \text { South Platte Natural Resources District } \\ \text { TDEM } & \text { time-domain electromagnetic sounding } \\ \text { USGS } & \text { U.S. Geological Survey }\end{array}$





\title{
Airborne Electromagnetic Mapping of the Base of Aquifer in Areas of Western Nebraska
}

\author{
By Jared D. Abraham, James C. Cannia, Paul A. Bedrosian, Michaela R. Johnson, Lyndsay B. Ball, \\ and Steven S. Sibray
}

\section{Abstract}

Airborne geophysical surveys of selected areas of the North and South Platte River valleys of Nebraska, including Lodgepole Creek valley, collected data to map aquifers and bedrock topography and thus improve the understanding of groundwater-surface-water relationships to be used in water-management decisions. Frequencydomain helicopter electromagnetic surveys, using a unique survey flight-line design, collected resistivity data that can be related to lithologic information for refinement of groundwater model inputs. To make the geophysical data useful to multidimensional groundwater models, numerical inversion converted measured data into a depth-dependent subsurface resistivity model. The inverted resistivity model, along with sensitivity analyses and test-hole information, is used to identify hydrogeologic features such as bedrock highs and paleochannels, to improve estimates of groundwater storage. The two- and three-dimensional interpretations provide the groundwater modeler with a high-resolution hydrogeologic framework and a quantitative estimate of framework uncertainty.

The new hydrogeologic frameworks improve the understanding of the flow path orientation by refining the location of the paleochannels and associated base of aquifer highs. These interpretations provide resource managers high-resolution hydrogeologic frameworks and quantitative estimates of framework uncertainty. The improved base of aquifer configuration represents the hydrogeology at a level of detail not achievable with previously available data.

\section{Introduction}

Water resources in the North and South Platte River valleys of Nebraska, inclusive of Lodgepole Creek, are critical to the social and economic health of the area and the management of endangered species along the Platte River corridor. Water, both surface water and groundwater, is a heavily used and regulated resource in the study area and in the entire Platte River Basin. Agriculture and power generation are the main drivers of the socioeconomics of western Nebraska and the largest users of water. In addition to this primary water utilization is the need to provide water for the recovery of threatened and endangered species in the Platte River Basin. The Platte River Recovery and Implementation Program (PRRIP) is a partnership between the U.S. Department of Interior and the States of Wyoming, Colorado, and Nebraska to manage habitat and water for the threatened and endangered species in the Big Bend Reach (fig. 1) of the Platte River (Platte River Recovery and Implementation Plan, 2011). The water for the program is stored or passed through Lake McConaughy, which is the lowest reservoir on the North Platte River, or is received from the South Platte River. Some of the water from the North Platte River is distributed downstream to critical reaches of the Platte River. Prior to reaching Lake McConaughy, surface water passes through many reservoirs, canal systems, and tributaries, and provides a large percentage of recharge to the aquifers within the alluvial valley floor. Conditions are similar in the South Platte River valley and to a lesser extent in Lodgepole Creek. Understanding the complex groundwatersurface-water interactions of the North and South Platte Rivers and Lodgepole Creek allows managers to better control the limited supplies of water for all uses, including those required by endangered species.

Protection of endangered species is not the only concern of water managers along the North and South Platte Rivers. Irrigation is the dominant water use, which in most instances is provided by both surface-water and groundwater sources. Major groundwater-surface-water management issues related to water availability and water quality for humans exist both locally and downstream. The study area covers parts of the Nebraska Panhandle that receive between 30.4 and $40.6 \mathrm{~cm}$ (12.0 and 16.0 in., respectively) of rainfall annually (University of Nebraska-Lincoln, 2010). Supplemental water through irrigation from both groundwater and surface water is necessary for agriculture. In the South Platte River and Lodgepole Creek drainage basins, dual sources (both surface water and groundwater) are used to irrigate approximately 54,000 ha (133,000 acres) of crops (South Platte Natural 


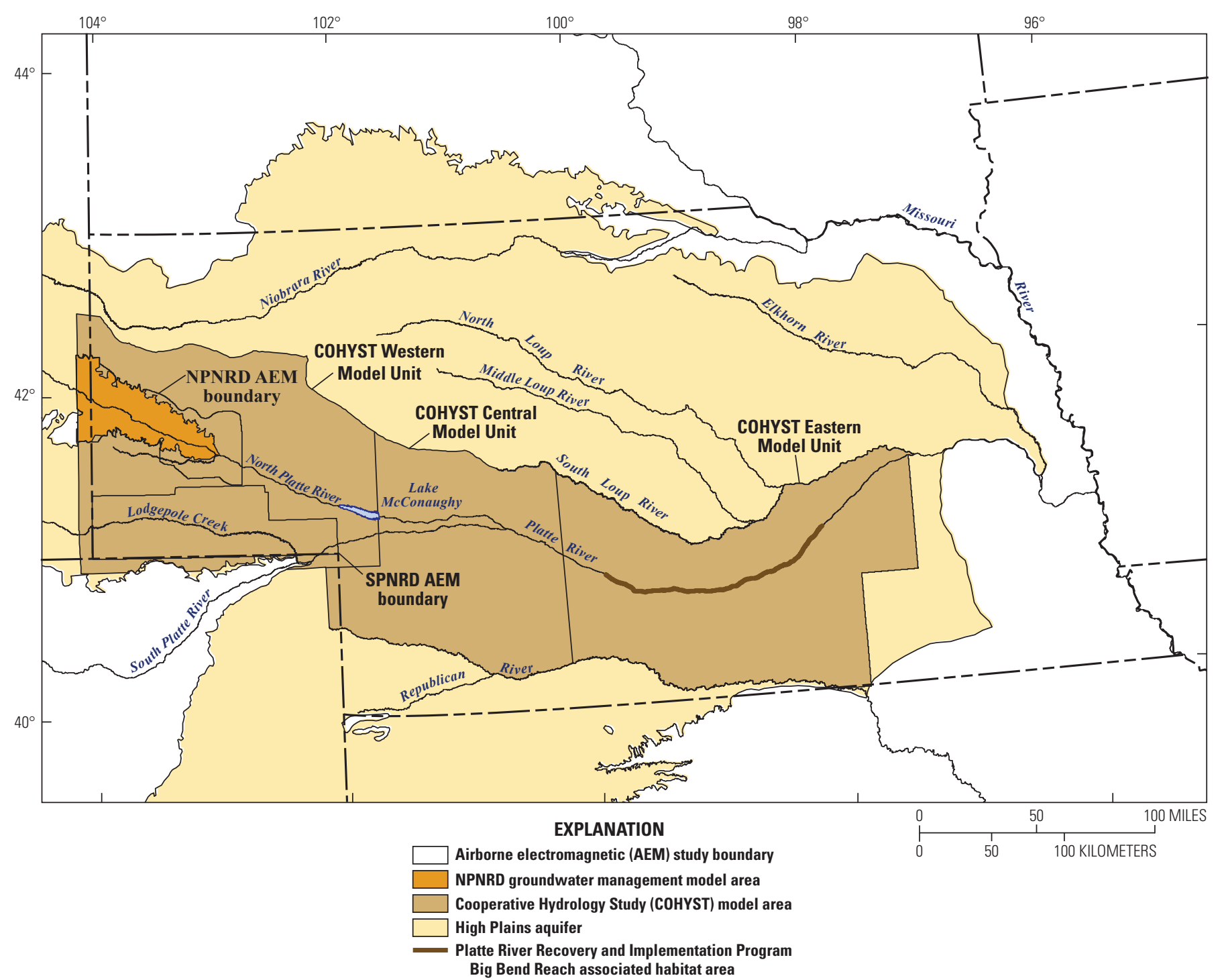

Figure 1. Location of the geophysical survey areas within the North and South Platte Natural Resources Districts (NPNRD and SPNRD, respectively), Nebraska, relative to existing hydrologic studies of the Platte River Basin. The High Plains aquifer boundary is shown as delineated by Qi (2010).

Resources District, 2008). Much of the water provided for irrigation is used and reused many times along its course downstream. The use of dual-source water creates a complex interaction between its source and its fate, making the management of the water challenging. Furthermore, water quality is affected by anthropogenic activities, such as crop fertilization, pest management, and sanitation.

Because of the multiple water uses and the consequent management challenges, additional data regarding water resources are required for use in the USGS High Plains Groundwater Water Availability Study (Qi, 2010; Qi and Christenson, 2010) and the Cooperative Hydrology Study (COHYST) (Carney, 2008; Peterson, 2007; Luckey and Cannia, 2006). Additionally, water-resources data are actively being incorporated within the Simulation of Groundwater Flow and Analysis of the Effects of the Water Management Options in the North Platte Natural Resources District (NPNRD) Study, which will be referred to in this report as the NPNRD Groundwater Management Model (S. M. Peterson, USGS, oral commun., 2011). Refinement of aquifer configuration will improve the reliability of the predictions made with these models. One approach to deriving and refining aquifer configuration is the use of airborne electromagnetic (AEM) surveys.

The U.S. Geological Survey and its partners have collaborated to use airborne geophysical surveys for areas of the North and South Platte River valleys including Lodgepole Creek in western Nebraska. The objective of the surveys was to map the aquifers and bedrock topography of selected areas to help improve the understanding of groundwatersurface-water relationships to be used in water-management decisions. This project was funded by in part by the Nebraska Environmental Trust Fund, NPNRD, the South Platte Natural Resources District (SPNRD), and the USGS Cooperative Hydrology Program. 


\section{Purpose and Scope}

This report presents the analysis and interpretation of the AEM surveys conducted in western Nebraska in 2008 and 2009 (figs. 1 and 2). This information will be used to improve the accuracy and representativeness of the existing hydrogeologic frameworks of the North and South Platte Natural Resources Districts (NPNRD and SPNRD, respectively). The revised base of aquifer (BOA) maps presented here can be incorporated into groundwater models of the areas of the NPNRD and the SPNRD. Also included in this report are comparisons of sediment saturated thickness and estimated groundwater storage between the new BOA, including the additions related to the AEM and time-domain electromagnetic (TDEM) interpretations presented here, and the BOA defined in previously published work.

\section{Description of Study Area}

The study area is in the panhandle of western Nebraska (fig. 1), which is characterized by river bottomland, terraces with upland areas, escarpments of tablelands, and tablelands. Main drainages are Lodgepole Creek and North Platte River valleys. The study methods and approaches described later

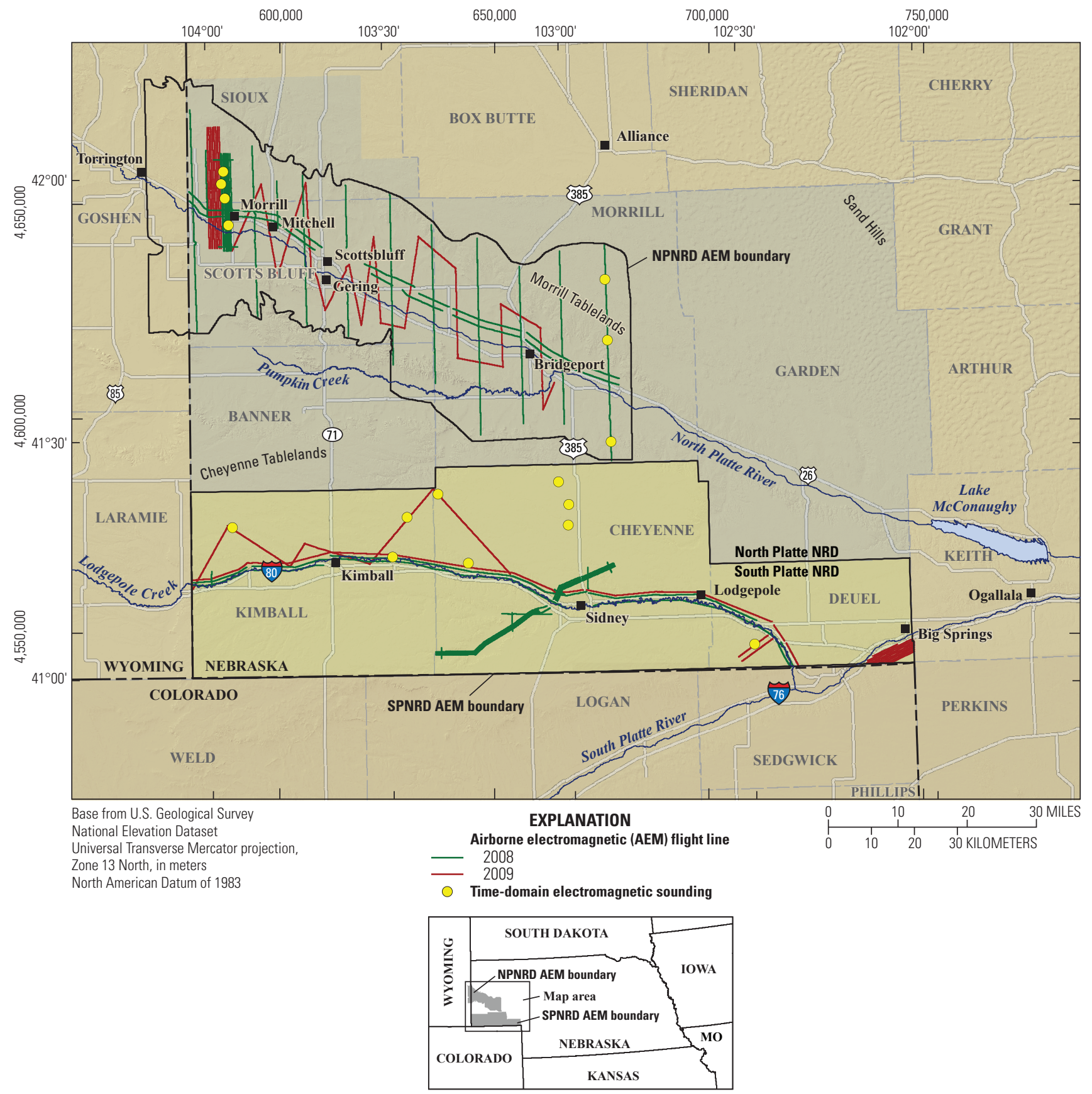

Figure 2. Location of geophysical data collection within the North and South Platte Natural Resource Districts (NPNRD and SPNRD, respectively), Nebraska. 
in this report were applied to the two separate river basins, the North Platte River and the South Platte River, the latter including the valley of Lodgepole Creek (figs. 1 and 2). For this reason, the study area for this report is considered to be the entire area included in the Western COHYST groundwater model (fig. 1) of Luckey and Cannia (2006).

The Western COHYST groundwater model simulates an area (fig. 1) that extends about $209 \mathrm{~km}(130 \mathrm{mi})$ from east to west by $140 \mathrm{~km}(87 \mathrm{mi})$ from north to south and covers 2,900 ha (7,166 acres). About 90,000 people inhabit the area. Agriculture dominates the livelihood and landscape of the region, and crops in the valleys are irrigated with both surface water and groundwater. Upland areas are used primarily for grazing, dry-land crops, and crops irrigated with groundwater from the High Plains aquifer. The topography varies from nearly flat areas, such as tablelands and floodplains, to hummocky sand dunes. The climate is semiarid. The mean annual precipitation at the Scottsbluff Airport was $38.7 \mathrm{~cm}$ (15.2 in.) for 1893-2010 (University of Nebraska-Lincoln, 2010). Most of the precipitation falls in the summer, with about two-thirds of the annual total occurring from May through September. Abundant sunshine, frequent winds, and low humidity result in a relatively high rate of evaporation. The long-term estimated mean annual evaporative demand (Luckey and Cannia, 2006) near Mitchell, Nebr., was $40.6 \mathrm{~cm} /$ year (16.0 in./year).

\section{Previous Work}

\section{Cooperative Hydrology Study}

The Cooperative Hydrology Study, or COHYST, is a hydrogeologic study of surface water and groundwater resources in the Platte River Basin. Information relating to COHYST and the products produced by that study can be found at the website http://cohyst.dnr.ne.gov/. The COHYST area covers approximately 470,000 ha $(1,161,370$ acres $)$ in west-central Nebraska (fig. 1). The western and southwestern boundaries of the study area were placed approximately $10 \mathrm{~km}$ (6.2 mi) inside the Colorado and Wyoming state lines, the north and south boundaries roughly follow the South Loup and Republican Rivers, and the study's eastern boundary was placed along county boundaries.

The COHYST was started in 1998 to develop scientifically supportable hydrologic databases, analyses, models, and other information products, which, when completed, will:

1. Assist Nebraska in meeting obligations under the PRRIP.

2. Assist Nebraska's Natural Resources Districts along the Platte River in providing appropriate regulation and management of water resources.

3. Provide Nebraskans with a basis to develop policy and procedures related to groundwater and surface water.

4. Help Nebraskans analyze proposed activities of the PRRIP and/or other water management programs in Nebraska.
The single-layer model of the Western COHYST groundwater model was published in Luckey and Cannia (2006) and was of particular importance to the design of the project described in this report. When developing the multilayer MODFLOW model for the Western COHYST groundwater model, unknowns in the poorly constrained hydrogeologic framework led to numeric instability when using MODFLOW. Similar difficulties arose during the development of NPNRD Groundwater Management Model (S. M. Peterson, oral commun., 2011). Awareness of these deficiencies in the hydrogeologic framework related to the models guided the selection of the locations and orientations of the AEM survey flight lines used in this project.

\section{Canal Leakage Potential}

A companion study to this project was mapping the surface-water irrigation canals in the North Platte valley to determine leakage potential. Surface geophysical surveys along 13 different canals produced $630 \mathrm{~km}(391 \mathrm{mi})$ of resistivity profiles. These data were used to create a map of near-surface (depth less than $10 \mathrm{~m}$, or $33 \mathrm{ft}$ ) resistivity that was interpreted on the basis of data from continuous sediment cores. Areas of high rates of canal leakage are associated with coarse sediments, sand, and gravel; areas of low canal leakage are associated with fine-grained sediments, silts, clays, and siltstones (Ball and others, 2006; Burton and others, 2009). The NPNRD Groundwater Management Model (S. M. Peterson, oral commun., 2011) uses this information to assign a leakage value (recharge) from the canal to the aquifer. When the canal leakage data are used in conjunction with the data collected in the study described in this report, a hydrogeologic framework that associates recharge areas with aquifer thickness and configuration allows for development of a groundwater model that realistically represents the groundwater flow system with spatial resolution that is not repeatable using other methods.

\section{Hydrogeology}

The geology and the occurrence of groundwater in the study area have been described by many earlier investigators, including Darton (1903a, b); Meinzer (1923); Lugn (1935); Wenzel and others (1946); Tychsen (1954); Bjorklund (1957); Lowry (1966); Smith (1969); Smith and Souders (1971, 1975); Swinehart and others (1985); Barrash (1986); Souders (1986); Goodwin and Diffendal (1987); Sibray and Zhang (1994); Verstraeten and others (1995); Terry (1998); and Steele and others (2007). The hydrogeologic units of the study area are described in table 1 and summarized graphically in figure 3 . The stratigraphic nomenclature used in this report conforms to usage as described by Swinehart and others (1985), with the exception of that for the Eocene epoch. Terry (1998) divided the Eocene in Nebraska into the Chadron Formation and the Chamberlain Pass 
Formation. The geologic formations and their corresponding hydrostratigraphic unit names from the COHYST groundwater model are described in the following paragraphs.

The youngest aquifers in the study area are the Quaternary alluvial and eolian aquifers, collectively designated hydrostratigraphic unit 2 (HU 2), which were deposited in the North Platte, South Platte, Pumpkin Creek, and Lodgepole Creek valleys. The sand and gravel of the alluvial aquifer are relatively coarse-grained and yield large quantities of water for irrigation and other purposes. The greatest observed thickness of this aquifer $(76.2 \mathrm{~m}$, or $250 \mathrm{ft})$ is in the North Platte River valley, where wells rarely penetrate the full saturated thickness of the unit. This aquifer is much thinner in the other valleys of the study area. Depth to water is generally shallow, ranging from land surface to more than 30.48 meters ( 100 feet), and water quality is generally considered "good" except where it is locally contaminated by the effects of human activity. In the North Platte valley, the BOA is defined by the underlying Brule Formation (Oligocene), except for the very deepest sections of the North Platte River channels, west of Mitchell, Nebr., which are eroded into undifferentiated Cretaceous-age sediments. In the Lodgepole Creek valley, the Quaternary alluvial aquifer can be found overlying the Ogallala aquifer as well as the Brule Formation. Saturated Quaternary eolian deposits of sand and silt are also present in the valleys and table lands. These deposits tend not to be extensive except in the Sand Hills region (fig. 2).

The Miocene Ogallala Group is the youngest Tertiaryage aquifer in the study area, where it is designated hydrostratigraphic unit 5 (HU 5). The Ogallala Group consists of inter-bedded sandstone, gravel, siltstone, and shale. This unit is the principal aquifer in the Cheyenne Tablelands in the southern part of the study area (fig. 2). The maximum thickness of the Ogallala Group exceeds $180 \mathrm{~m}(591 \mathrm{ft})$, and few irrigation wells penetrate the entire formation where it is thickest. In some areas, the Ogallala Group is thin and cemented by calcareous cement. In other areas, interbedded siltstone is widespread. The depth to water ranges from greater than $61 \mathrm{~m}$ (200 ft) on the Cheyenne Tableland to land surface in the Lodgepole Creek valley. Well yields are generally adequate for irrigation but are highly variable depending on the local geology.

The Arikaree Group consists of very fine- to finegrained sandstone with some coarse-grained material. Where saturated, the Arikaree Group constitutes an aquifer designated as hydrostratigraphic unit 7 (HU 7). Lenses of carbonate cementation and ash beds are present. Well yields are moderate, but the areal extent of this aquifer is relatively small due to its removal by erosion prior to the deposition of the Ogallala Group and the Quaternary alluvium. The Arikaree Group is found in the tableland areas and typically underlies the Ogallala Group aquifer.

The Brule Formation is divided into hydrostratigraphic units 8 and 9. Unit HU 8 contains small local aquifers when saturated, and HU 9 is an aquitard of regional extent. The aquifers of HU 8 are fractured zones that occur in the uppermost section of the formation. They are very limited in areal extent within the North Platte River and Lodgepole Creek valleys. These fractured zones can provide large quantities of water to wells when hydrologically and hydraulically connected to additional sources of water such as streams or other aquifers (Barrash, 1986). The fractured zones are horizontal to subhorizontal (Barrash, 1986) and are limited to the valley areas (Lowry, 1966). Sibray and Zhang (1994) found that the storativity of the fracture system was low and that secondary permeability was limited to shallow depths. Locally fractured Brule aquifer units are sensitive to drought unless hydrologically and hydraulically connected to overlying saturated Quaternary sand and gravel or to surfacewater features.

The part of the Brule Formation within HU 9 is typified as a very thick (more than $180 \mathrm{~m}$, or $591 \mathrm{ft}$ ) sequence of lowpermeability, interbedded brown siltstone and mudstone with channel deposits of sandstone with locally present gravel. In most of the study area, the top of the Brule Formation is the base of the regional unconfined aquifer system. The sandstones in small pockets in channel deposits yield only enough water for domestic and livestock wells. Brule Formation sand- and gravel-filled channel deposits that yield moderate amounts of water are rare.

Underlying the Brule Formation confining unit (the part designated HU 9) is the Chadron Formation, which is a regional confining unit of bentonitic shales and mudstones. This layer (usually 15 to $18 \mathrm{~m}$, or about 49 to $60 \mathrm{ft}$ thick) separates the unconfined aquifer systems from the confined aquifers. The confined aquifer of the Chamberlain Pass formation is found only in the Eocene paleovalleys (Swinehart and others, 1985). This aquifer consists of interbedded medium- to coarse-grained subarkosic sandstone with some gravel and is typically 5 to $6 \mathrm{~m}$ (about 16 to $20 \mathrm{ft}$ ) thick. For purposes of this report both of these formations are isolated from the overlying unconfined aquifers and are assigned to HU 9.

The undifferentiated Cretaceous confined aquifer is present only locally in the western part of the study area, where it is designated hydrostratigraphic unit 10 (HU 10). This aquifer contains relatively poor-quality water and is developed only where no other source of water is available.

\section{Test-hole Logs}

In 1930, the Conservation and Survey Division (CSD) of the University of Nebraska and the U.S. Geological Survey began cooperative studies of groundwater in Nebraska. An integral part of the study was the drilling of test holes, which has continued to the present (2011). The Conservation and Survey Division has published test-hole logbooks for all Nebraska counties in the study area. These logbooks compile available data for each test hole, including analyses of drill cuttings and lithologic logs, interpretations of geophysical borehole logs, reviews of test-hole locations and elevation, and the results of other research to define geological parameters. 
Table 1. Principal hydrogeologic units of the Cooperative Hydrology Study (COHYST) Western Groundwater Model area, Nebraska (modified from Cannia and others, 2006).

[Abbreviation: Ma, age before present in millions of years; gpm, gallons per minute.]

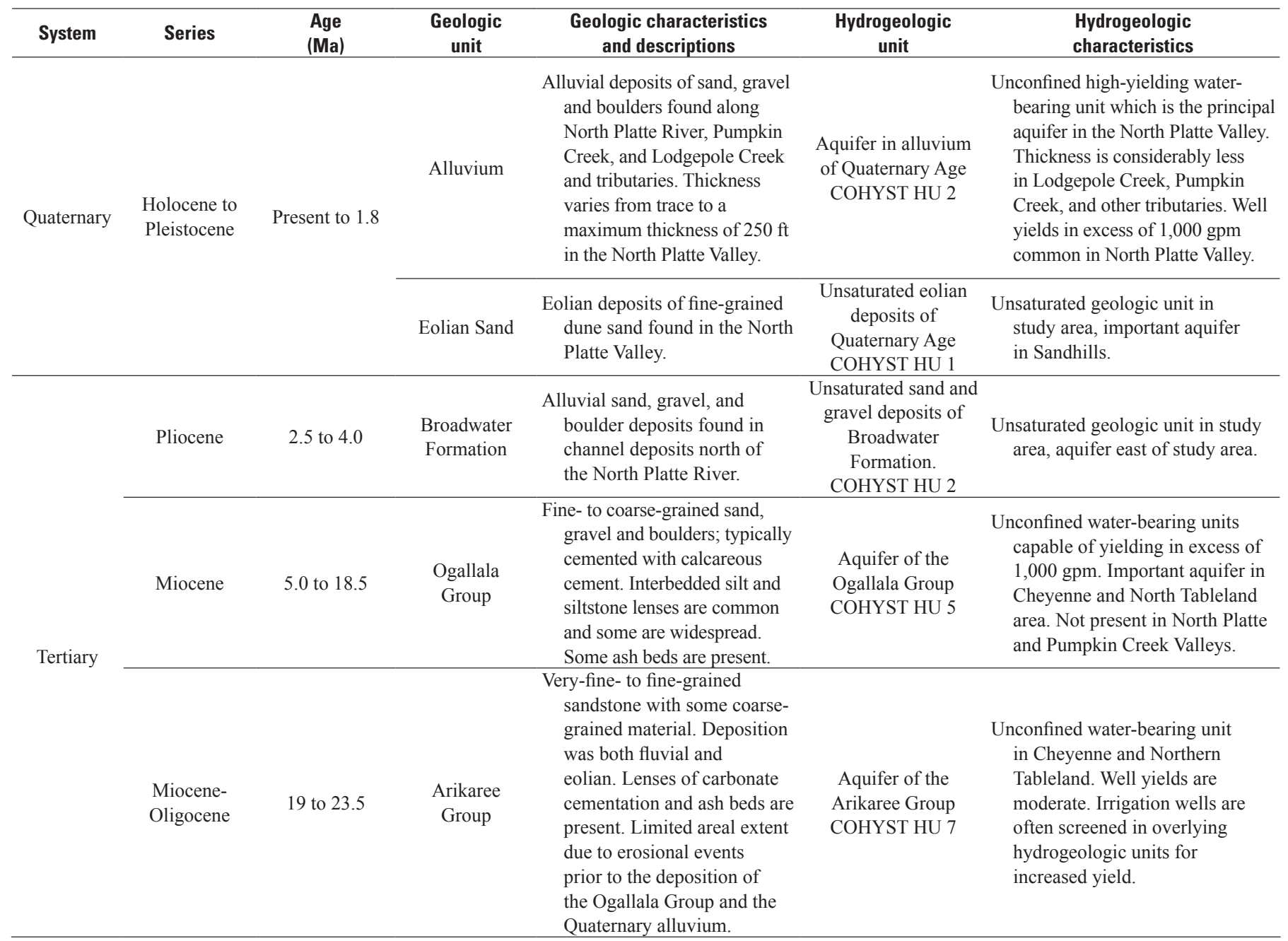

Complete and accurate site location descriptions were the primary concern when evaluating whether or not to add a well $\log$ to the COHYST database. All sites in the COHYST database include county, Township, Range, section and quarter-section information. Some locations were precise down to a 1-ha (2.47-acre) plot and/or included distance from a section corner. If global positioning-system coordinates were available, they were included as direct inputs to the $\mathrm{X}-\mathrm{Y}$ coordinates of the database. Surficial geologic maps were digitized for use in determining the location of (geologic) formation outcrops.

Land-surface elevations were determined for each well/ $\log$ location by calculating an elevation from USGS 30-m digital elevation models (DEM) for the COHYST area. Elevations for all sites are included in the COHYST database. A contour map of land-surface elevation at $100-\mathrm{ft}(30.48-\mathrm{m})$ intervals was created from the 1:24,000-scale topographic maps for the COHYST area. That map was used to determine elevation for the outcrop areas.
Clarity of the lithologic description was the next most important criterion considered for selecting well logs for inclusion in the database. The lithologic descriptions in the CSD test-hole logbooks were the most precise available for the study area. Those records include detailed descriptions of grain size, sorting, cementation, mineralogy, color, fossils, and penetrated geologic formations. Some of the records included geophysical logs, typically some combination of resistivity, spontaneous potential, and natural gamma logs. Total depth drilled and geologic formations penetrated were the last criteria evaluated for wells included in the database. Lithologic logs that were the most valuable to this process are from wells and test holes that were drilled into the White River Group or into Cretaceous hydrostratigraphic units simulated in the groundwater models. Those logs that penetrated more than one geologic formation were the next most useful. Those that were completed in one formation without completely penetrating it were least effective for the purposes of this study. 
Table 1. Principal hydrogeologic units of the Cooperative Hydrology Study (COHYST) Western Groundwater Model area, Nebraska (modified from Cannia and others, 2006).-Continued

[Abbreviation: Ma, age before present in millions of years; gpm, gallons per minute.]

\begin{tabular}{|c|c|c|c|c|c|c|c|}
\hline System & Series & Age (Ma) & $\begin{array}{l}\text { Geologic } \\
\text { unit }\end{array}$ & $\begin{array}{c}\text { Geologic characteristics } \\
\text { and descriptions }\end{array}$ & Hydro & $\begin{array}{l}\text { geologic } \\
\text { unit }\end{array}$ & $\begin{array}{l}\text { Hydrogeologic } \\
\text { characteristics }\end{array}$ \\
\hline \multirow{5}{*}{ Tertiary } & \multirow{3}{*}{ Oligocene } & \multirow{3}{*}{30 to 33.7} & \multirow{3}{*}{$\begin{array}{l}\text { Brule } \\
\text { Formation }\end{array}$} & \multirow{3}{*}{$\begin{array}{l}\text { Brown siltstone and } \\
\text { mudstone rich in } \\
\text { volcanic glass shards. } \\
\text { Discrete ash beds can } \\
\text { be correlated over } \\
\text { wide areas. Local } \\
\text { channel deposits of } \\
\text { sand, sandstone, and } \\
\text { gravel are present. }\end{array}$} & \multirow{2}{*}{$\begin{array}{c}\text { Brule } \\
\text { Formation } \\
\text { water bearing } \\
\text { units }\end{array}$} & $\begin{array}{l}\text { Fractured water } \\
\text { bearing Units } \\
\text { COHYST HU } 8\end{array}$ & $\begin{array}{l}\text { Unconfined fractured water-bearing unit } \\
\text { may yield large volumes of water with } \\
\text { little drawdown. Storativity is low } \\
\text { except where overlain by saturated } \\
\text { alluvial deposits. Fractured Brule } \\
\text { aquifer only occurs in the North Platte, } \\
\text { Pumpkin Creek, and Lodgepole valleys. }\end{array}$ \\
\hline & & & & & & $\begin{array}{l}\text { Aquifer in Brule } \\
\text { Formation sand } \\
\text { and gravel unit } \\
\text { COHYST HU } 8\end{array}$ & $\begin{array}{l}\text { Can be unconfined or confined, yields } \\
\text { small quantities of water (less than } \\
50 \text { gpm) for domestic and livestock } \\
\text { purposes. Gravel unit can yield } \\
\text { moderate amounts of water for } \\
\text { irrigation in only a few localized areas. }\end{array}$ \\
\hline & & & & & \multicolumn{2}{|c|}{$\begin{array}{l}\text { Brule Formation Aquitard } \\
\text { COHYST HU } 9\end{array}$} & $\begin{array}{l}\text { Not a source of water. Serves as bedrock } \\
\text { in the study area. }\end{array}$ \\
\hline & \multirow[b]{2}{*}{ Eocene } & 33.7 to 37 & $\begin{array}{l}\text { Chadron } \\
\text { Formation }\end{array}$ & $\begin{array}{l}\text { Green to greenish grey } \\
\text { bentonitic mudstone } \\
\text { and claystone. }\end{array}$ & \multicolumn{2}{|c|}{$\begin{array}{l}\text { Chadron Formation } \\
\text { confining unit } \\
\text { COHYST HU } 9 \\
\end{array}$} & $\begin{array}{l}\text { Regional confining layer separates the } \\
\text { generally unconfined water bearing } \\
\text { units from the older confined units. }\end{array}$ \\
\hline & & 37 to ? & $\begin{array}{l}\text { Chamberlain } \\
\text { Pass Formation }\end{array}$ & $\begin{array}{l}\text { Medium to coarse } \\
\text { sand and gravel } \\
\text { deposited in a fluvial } \\
\text { environment. Some } \\
\text { interbedded bentonitic } \\
\text { mudstone and } \\
\text { claystone. Deposited } \\
\text { in paleovalleys. }\end{array}$ & $\begin{array}{l}\text { Chamb } \\
\text { Format } \\
\text { COHY }\end{array}$ & $\begin{array}{l}\text { erlain Pass } \\
\text { ion aquifer } \\
\text { ST HU } 9\end{array}$ & $\begin{array}{l}\text { Confined water-bearing unit rarely used } \\
\text { for irrigation due to its great depth and } \\
\text { poor water quality. Saturated thickness } \\
\text { exceeds } 100 \mathrm{ft} \text { in small localized areas. }\end{array}$ \\
\hline \multirow{2}{*}{ Cretaceous } & \multirow{2}{*}{$\begin{array}{c}\text { Upper } \\
\text { Cretaceous }\end{array}$} & \multirow{2}{*}{66.5 to 71} & $\begin{array}{l}\text { Fox Hills } \\
\text { Formation }\end{array}$ & $\begin{array}{l}\text { Yellow to yellowish } \\
\text { green, fine- to } \\
\text { medium-grained } \\
\text { sandstone with some } \\
\text { interbedded grey shale. }\end{array}$ & $\begin{array}{l}\text { Fox Hi } \\
\text { COHY }\end{array}$ & $\begin{array}{l}\text { lls Aquifer } \\
\text { ST HU } 10\end{array}$ & $\begin{array}{l}\text { Confined water-bearing unit used for stock } \\
\text { and domestic wells in areas where no } \\
\text { other source of water is available. Used } \\
\text { mainly in Western Kimball, Banner and } \\
\text { Southwestern Scotts Bluff Counties. } \\
\end{array}$ \\
\hline & & & $\begin{array}{l}\text { Pierre } \\
\text { Formation }\end{array}$ & $\begin{array}{l}\text { Grey to grey black marine } \\
\text { shale, very minor } \\
\text { thin beds of very fine } \\
\text { grained sandstone in } \\
\text { western part. }\end{array}$ & \multicolumn{2}{|c|}{$\begin{array}{l}\text { Pierre shale confining unit } \\
\text { COHYST HU } 10\end{array}$} & Generally, not a source of water. \\
\hline
\end{tabular}

\section{Geophysical Properties}

\section{Electrical Rock Properties}

Electromagnetic geophysical methods detect variations in the electrical properties of rocks, in particular, electrical resistivity or its reciprocal, electrical conductivity. Electrical resistivity can be correlated with geologic units on the surface and at depth using lithologic logs to provide a 3-D representation of subsurface geology. In the upper crust, the resistivities of geologic units are largely dependent upon their fluid content, pore-volume porosity, interconnected fracture porosity, and conductive mineral content (Keller, 1989). While there is no one-to-one relationship between lithology and resistivity, some general correlations can be made on the basis of typical ranges of values for a variety of rocks, minerals, and geological environments presented in Keller (1987) and Palacky (1987). Resistivity values, however, may fall outside the ranges suggested by those authors. Fluids within the pore spaces and fracture openings, especially if saline, can reduce electrical resistivities in what would otherwise be a resistive rock matrix. Resistivity also can be lowered by the presence of electrically conductive clay minerals, graphitic carbon, and metallic mineralization. Fine-grained sediments, such as clay-rich alluvium, marine shale, and mudstone typically are conductive - from a few ohm-meters to a few tens of ohm-meters. Metamorphic rocks (nongraphitic) and unaltered, unfractured igneous rocks typically are moderately to highly resistive (a few hundreds to thousands of ohm-meters). Carbonate rocks can have similarly high resistivities depending on fluid content, porosity, and impurities.

\section{Electrical Properties from Boreholes in Study Area}

Geological data gathered from boreholes as part of COHYST work indicated that BOA was primarily HU 8 and HU 9. In limited areas, the BOA was HU 10. Typical mapped materials included (1) HU 2, Quaternary alluvial/valley-fill deposits with resistivity values typically from 50 to $500 \mathrm{ohm}-\mathrm{m}$, and HU 5, fluvial siltstones, sandstones, and gravels with resistivities typically from 40 to $100 \mathrm{ohm}-\mathrm{m}$; (2) HU 7, 


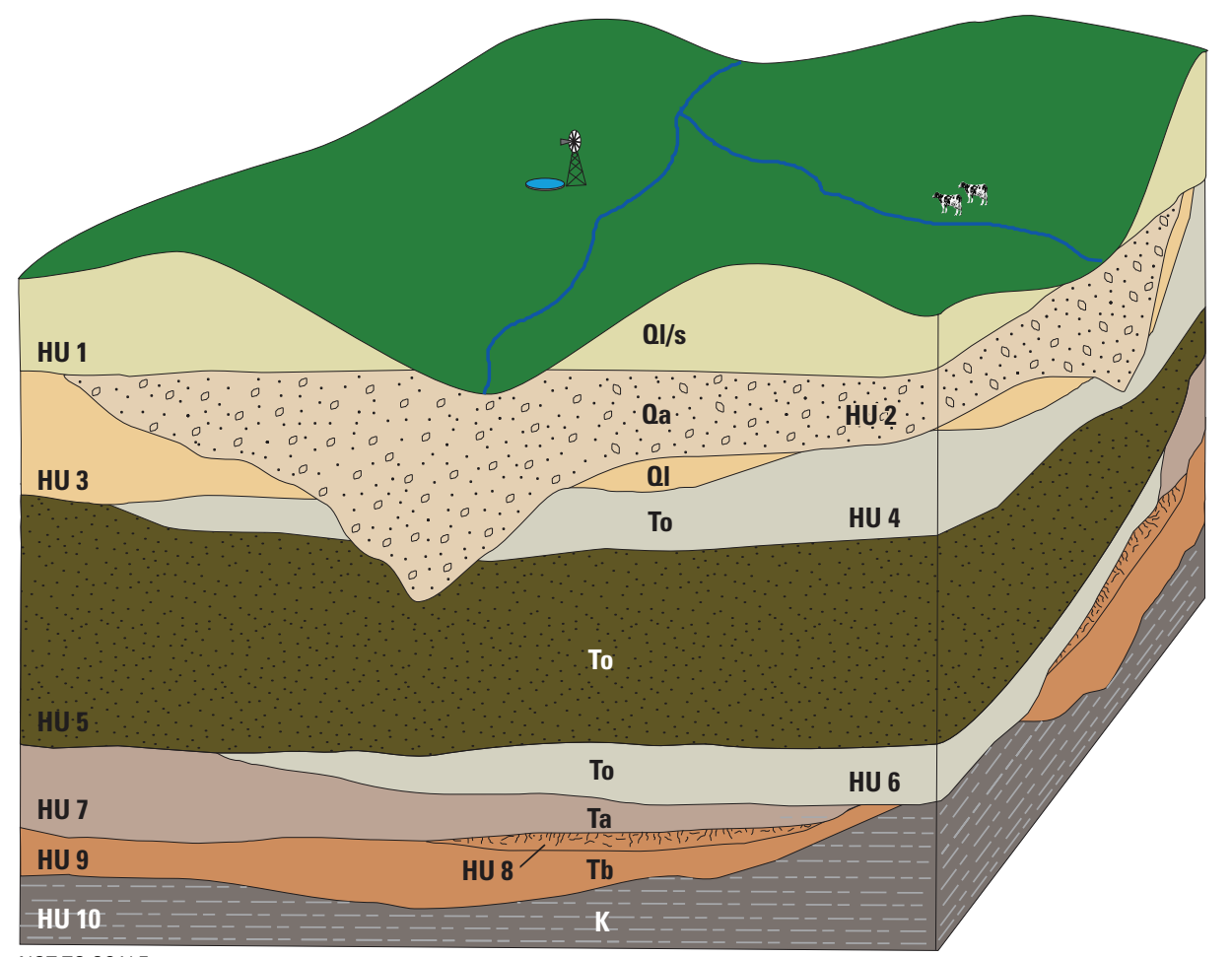

NOT TO SCALE

\begin{tabular}{|c|c|c|}
\hline \multicolumn{3}{|c|}{ EXPLANATION } \\
\hline Form & tion/group description & $\begin{array}{l}\text { Hydrostratigraphic unit } \\
\text { (HU) }\end{array}$ \\
\hline $01 / \mathrm{s}$ & Fines loess or dune sand (Quaternary) & 1 \\
\hline 0 & Alluvial/valley fill deposits (Quaternary) & 2 \\
\hline Oll & Fines loess/silt (Quaternary) & 3 \\
\hline \begin{tabular}{|l|l} 
To \\
\end{tabular} & Ogallala Group silts/siltstones (Tertiary) & 4,6 \\
\hline 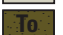 & Ogallala Group sands/sandstones (Tertiary) & 5 \\
\hline Ta & Arikaree Group sandstones/siltstones (Tertiary) & 7 \\
\hline BT, & $\begin{array}{l}\text { White River Group (Tertiary)—Brule Formation } \\
\text { fractured siltstones }\end{array}$ & 8 \\
\hline Tb & $\begin{array}{l}\text { White River Group (Tertiary)—Brule Formation } \\
\text { siltstones/sandstones }\end{array}$ & 9 \\
\hline EE & Undifferentiated units (base of aquifer) (Cretaceous) & 10 \\
\hline
\end{tabular}

Figure 3. Hydrostratigraphic units in the Cooperative Hydrologic Study area, Nebraska..

fine-grained, well-sorted sand and sandstone with resistivities typically from 250 to $400 \mathrm{ohm}-\mathrm{m}$, above HU 8 and HU 9, and fractured and unfractured siltstone with resistivities typically from 8 to $20 \mathrm{ohm}-\mathrm{m}$; and, in a few places, (3) HU 10, marine shale with resistivities typically from 3 to $10 \mathrm{ohm}-\mathrm{m}$ (fig. 3). Borehole geophysical logs acquired by the CSD indicated that the primary aquifers (HU 2, 5, and 7) are electrically resistive (40 to $400 \mathrm{ohm}-\mathrm{m}$ ) and the underlying confining units (HU 8, 9 , and 10) are electrically conductive ( 3 to $20 \mathrm{ohm}-\mathrm{m}$ ). This difference provides a detectable electrical contrast between the aquifer material and the confining unit. The only place in the project area where electrical properties deviate appreciably from values typical for the rock types present is in a small area where saline groundwater is known to be present. It is near the town of Morrill, Nebr., and is confined to a wetland measuring approximately 65 ha (about 161 acres) in size. The saline waters near Morrill did not impact the interpretation of the AEM due to the shallow nature of HU 8 and 9 and the adequate test-hole control in the area.

\section{Study Methods and Approach}

\section{Airborne Electromagnetic Method}

Airborne electromagnetic (AEM) surveys, flown with either helicopter or fixed-wing aircraft, increasingly have been employed to characterize aquifers and their geologic setting (Smith and others, 2007). Such AEM surveys can provide characterization of electrical properties of earth materials from the near-surface 1 to $3 \mathrm{~m}$ ( 3.3 to $9.8 \mathrm{ft}$ ) down to depths of 300 to $400 \mathrm{~m}$ (984 to $1,312 \mathrm{ft}$ ). Typical AEM systems transmit an electromagnetic (radio-frequency) signal that interacts with the earth to generate (induce) secondary currents. Those secondary currents are a function of the subsurface electrical resistivity, which is controlled by the amount of mineralogical clay, gravel, water content (and the dissolved solids in the water), metallic mineralization, and void space. Measurements of the secondary currents are recorded either 
in the time domain (where the signal is a train of pulses and measurements are taken between the primary field pulses as a function of time as the secondary currents decay) or in the frequency domain (where the signal is a continuous wave and measurements are taken at the frequency of the primary field, which is still present). Using numerical imaging and inversion, depth sections of estimated electrical resistivity can be created along flight lines. Interpolations between flight lines provide estimation of the three-dimensional distribution of electrical resistivity.

\section{Data-Collection System}

The Fugro Airborne Surveys, Inc., RESOLVE frequency-domain helicopter AEM system was selected for data collection in the North Platte and South Platte valleys and along Lodgepole Creek. This system was selected on the basis of its capability to provide electrical resistivity-versus-depth information that was required for the groundwater model, given the previous knowledge of the geologic materials within the study area. The RESOLVE system images resistivity to depths of approximately $80 \mathrm{~m}(262 \mathrm{ft})$. The system is effective in distinguishing materials that act as electrical resistors overlying materials that act as electrical conductors, such as the earth materials in areas of western Nebraska. The RESOLVE system was configured to collect the components of the induced signal that are in-phase and outof-phase (quadrature) with the primary signal at six nominal frequencies, including 140,000, 40,000, 8,200, 3,300, 1,800, and 400 Hertz. Details on the survey specifications for the two surveys flown in this study can be found in Smith and others (2009) and Smith and others (2010).

\section{Survey Design}

Due to large areas encompassed by the groundwater models, and limited resources to gather additional information, an innovative approach to AEM data collection was implemented in the NPNRD and SPNRD. Combining information from a subset of the approximately $400 \mathrm{CSD}$ boreholes, approximately 2,600 registered irrigation wells, surface geologic maps, and the COHYST hydrostratigraphic units, a conceptual model was formulated for the Western Model area. That information was integrated with the NPNRD Groundwater Management Model (S. M. Peterson, oral commun., 2011), and areas where more information was needed were identified. Those areas were selected to be mapped with the AEM survey in two distinct manners (fig. 2). One flight plan configuration was to survey the blocks in typical fashion, with evenly spaced lines separated from 220 to $400 \mathrm{~m}$ (722 to 1,312 ft) and trending in a specific direction. The second configuration used widely spaced lines oriented in the direction likely to provide the widest areal coverage possible for identifying the BOA. These widely spaced lines were termed "reconnaissance lines" and provide an initial look into the subsurface in areas where the geologic framework of the groundwater model was poorly constrained.

\section{Data Processing and Inversion}

After processing by Fugro Airborne Surveys, Inc., the data were inverted using the University of British Columbia Geophysical Inversions Facilities program EM1DFM (Farquharson and others, 2003). After the data inversion, which means in this case solving for an underground distribution of resistivity which could have produced the AEM measurements, a depth of investigation (DOI) metric was calculated based on the approach described by Oldenburg and Li (1999). That approach combines multiple inversions from different reference models to define areas in which the models are no longer sensitive to the data, that is, where model resistivity values tend toward the reference model (Farquharson and others, 2003; Oldenburg and Li, 1999). This method allows the plotting of the data with a cutoff value to eliminate regions below the DOI (fig. 4), where the data are not sensitive to the model. The DOI provides the geophysicist and geologist with a level of confidence in interpreting resistivity values related to the feature being mapped. Details on the processing and inversion can be found in Smith and others (2009) and Smith and others (2010).

\section{Time-Domain Electromagnetic Method}

Time-domain electromagnetic (TDEM) sounding is an active-source inductive electromagnetic technique that provides subsurface resistivity constraints by passing current through a wire loop that generates a primary magnetic field according to Ampere's law (Fitterman and Labson, 2005). This primary current is rapidly turned on and off, thereby causing a change in magnetic flux, $\phi_{m}$, which induces a motional electromagnetic force, $E^{\prime}$, (hence eddy currents in conductive bodies) according to Faraday's Law:

$$
E^{\prime}=\frac{d}{d t} \phi_{m}
$$

where

$$
\phi_{m}=\int \vec{B} \cdot d \vec{A}
$$

$\vec{B}$ is the magnetic field,

and

$d \vec{A} \quad$ represents an elemental effective surface area.

In TDEM soundings, secondary magnetic fields are produced by the decay of the subsurface eddy and galvanic currents and are typically measured as voltage on a receiver coil at the surface. Via Faraday's Law, the horizontal receiver coil senses the time rate of change of the vertical component of $\vec{B}$.

An apparent resistivity, $\rho_{a}$, can be calculated from the measured voltage using the following expression for centralloop data in the late-stage formulation (Fitterman, 1989): 
where

$$
\rho_{a}=\frac{\mu}{4 \pi}\left(\frac{2 \mu I A_{T} A_{R}}{5 V}\right)^{2 / 3} t^{-5 / 3}
$$

$\rho_{a}$ is apparent resistivity [ohm-m],

$\mu$ is the magnetic permeability $[\mathrm{H} / \mathrm{m}]$,

$I$ is the transmitter current in the wire loop [A],

$A_{T}$ is the area of the transmitter loop $\left[\mathrm{m}^{2}\right]$,

$A_{R}$ is the effective area of the receiver loop, that is, the area within a single turn of the wire multiplied by the number of turns within the receiver coil $\left[\mathrm{m}^{2}\right]$,

$V$ is the voltage measured at receiver coil in the center of the loop [V],

and

$t$ is the time after transmitter current turn-off [s].
The apparent resistivity is solely a mathematical transform. However, it serves two important purposes. First, subtle differences in the measured receiver voltage due to changes in subsurface resistivity are accentuated by the power-law dependence of apparent resistivity on time and voltage. Second, the TDEM response of a homogeneous, isotropic half-space is such that the late-stage apparent resistivity is time dependent but asymptotic to the true half-space resistivity at late time. For more complicated, heterogeneous earth structure, the variation of apparent resistivity with time can be viewed as a proxy for the variation of true-earth resistivity with depth. The actual electrical resistivity distribution in the earth is computed from the apparent resistivity via the process of inversion. Additional details on the TDEM sounding method can be found in Nabighian and Macnae (1991), Danielsen and others (2003), Fitterman and Labson (2005), and Christiansen and others (2006). The TDEM technique is used to constrain subsurface
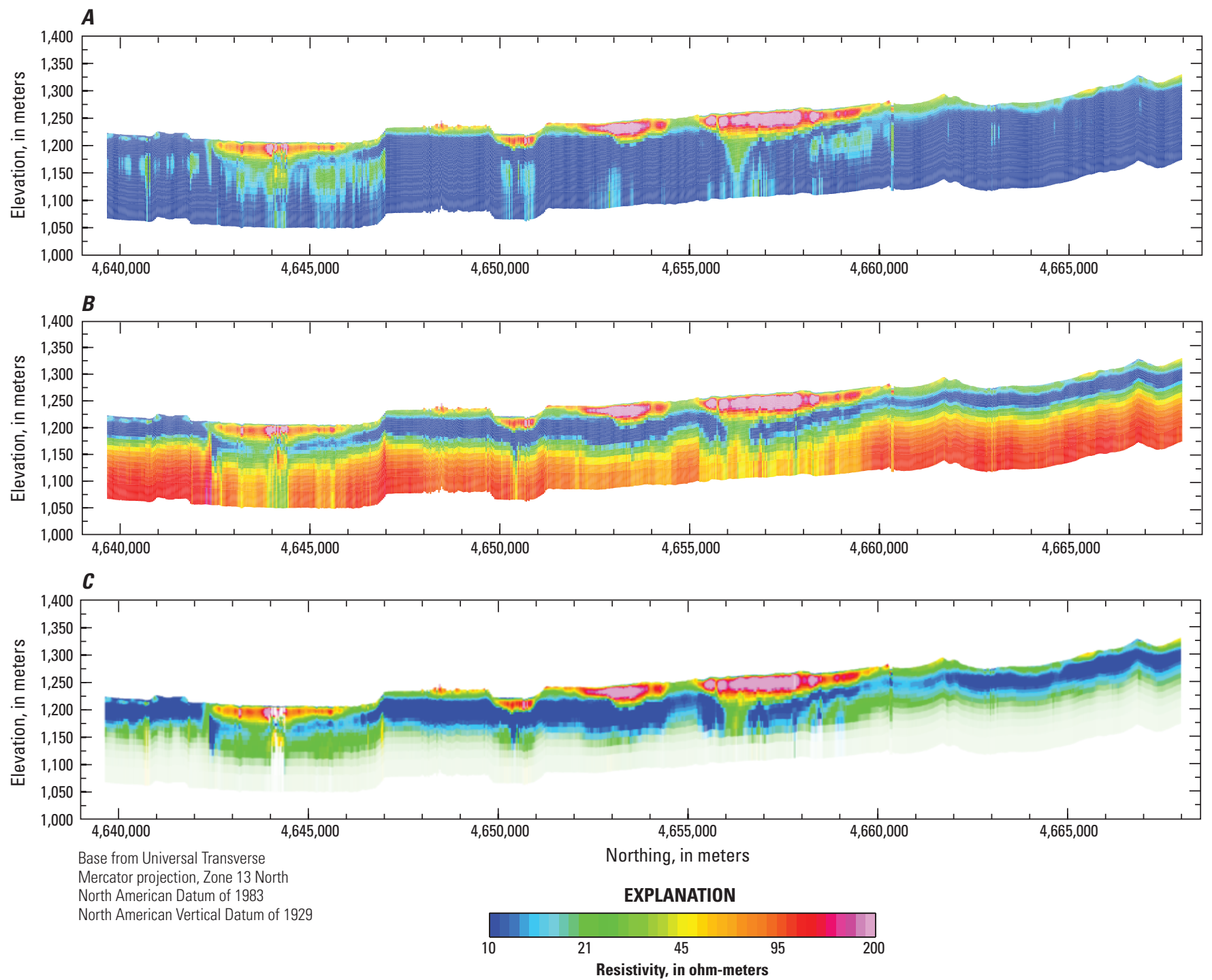

Figure 4. Examples of inverted airborne electromagnetic (AEM) profiles showing the depth-of-investigation metric. Reference models of $(A) 10$ and $(B) 100 \mathrm{ohm}-\mathrm{m}$ were used to rank the sensitivity of the model to the data. Where sensitivity exceeds the cut-off value, $(C)$, the model color fades to the background color. 
electrical resistivity structure, typically in the depth range from 50 to $500 \mathrm{~m}$ (164 to $1,640 \mathrm{ft}$ ). As such, it fills an important gap between near-surface geophysical survey techniques (for example, direct-current resistivity and capacitively coupled resistivity) and deeper techniques such as magnetotelluric methods. For this reason, TDEM is frequently used in hydrologic studies, especially in regions where deep hydrologic data are needed (Fitterman, 1988; Fitterman and Stewart, 1986). The TDEM was used in this study to supplement the AEM data by collecting deeper information in selected areas which the AEM did not image to depth(s) desirable for delineation of HUs 8,9 , and 10 with confidence.

\section{Ground-based Collection of Time-Domain Electromagnetic Data}

The TDEM data were collected at a total of 16 sites. Seven sites are within the NPNRD, and nine sites within the SPNRD (fig.2). Data were collected with the Geonics ProTEM system using the Geonics EM-47and EM-57 transmitters and the Zonge GDP-32 using the NanoTEM and ZTEM transmitters. Both 40-m (131-ft) and 100-m (328-ft) transmitter loops were used in data collection. Station locations are given in table 2.

\section{Analysis of Time-Domain Electromagnetic Data}

Data analysis for all TDEM soundings consisted of data format conversion, statistical analysis and averaging, forward modeling, data inversion, and model assessment. Data were processed and inverted using the SiTEM dataprocessing and Single-site Electromagnetic Data Inversion (SEMDI) software packages (Auken and Nebel, 2001). The SEMDI inversion permits full waveform specification, the modeling of system filters, and the incorporation of data errors. Furthermore, it provides error bounds on inverted-layer thicknesses and resistivities. Data were inverted for two endmember model classes - minimum-layer models and 20-layer smooth inverse models. The former class of models seeks to fit the measured data with as few distinct layers as possible, whereas the latter seeks to fit the data with a large number of thin layers under the constraint that the resistivity changes gradually between adjacent layers. Minimum-layer models may be more appropriate in settings where sharp variations in resistivity are expected, whereas smooth inverse models may be more realistic when gradational changes are expected. Independent data from geologic mapping, borehole lithology, and geophysical borehole logs typically are used to assess which of the above model classes may be more appropriate in interpreting subsurface structure.

Modeling and inversion of TDEM data are commonly one-dimensional (1-D). This assumption is reasonable given the nature of the regional geology and the limited depth of investigation (100 to $300 \mathrm{~m}$, or about 325 to $975 \mathrm{ft}$ ). Furthermore, lithologic logs from surrounding test holes show correlation across the study area. Finally, the layered-earth
Table 2. Station coordinates and elevations for ground-based time-domain electromagnetic (TDEM) soundings, North and South Platte Natural Resources Districts, Nebr.

\begin{tabular}{cccc}
\hline Site & $\begin{array}{c}\text { Latitude } \\
\text { (decimal degrees) }\end{array}$ & $\begin{array}{c}\text { Longitude } \\
\text { (decimal degrees) }\end{array}$ & $\begin{array}{c}\text { Elevation } \\
\text { (meters) }\end{array}$ \\
\hline \multicolumn{4}{c}{ South Platte Natural Resources District } \\
\hline SP0 & 41.31812 & -103.93742 & 1560.8 \\
SP1 & 41.25109 & -103.49303 & 1361.1 \\
SP2 & 41.33425 & -103.45033 & 1433.9 \\
SP3 & 41.38151 & -103.36286 & 1414.2 \\
SP4 & 41.23544 & -103.28324 & 1410.4 \\
SP5 & 41.40255 & -103.02603 & 1315.9 \\
SP6 & 41.35414 & -102.99910 & 1303.7 \\
SP7 & 41.31110 & -103.00255 & 1316.6 \\
SP8 & 41.05125 & -102.49332 & 1564.2 \\
\hline \multicolumn{5}{c}{ North Platte Natural Resources District } \\
\hline NP1 & 42.00914 & -103.94760 \\
NP2 & 42.03956 & -103.95701 & 1246.7 \\
NP3 & 42.06598 & -103.95127 & 1272.4 \\
NP4 & 41.95264 & -103.93909 & 1315.2 \\
NP5 & 41.82427 & -102.88421 & 1219.1 \\
NP6 & 41.69675 & -102.88035 & 1231.8 \\
NP7 & 41.48420 & -102.87766 & 1224.1 \\
\hline
\end{tabular}

assumption appears validated by the final 1-D inverse models, which, at least in the upper $100 \mathrm{~m}(328 \mathrm{ft})$, generally show smooth variation in interface depths from station to station.

All geophysical inversion problems exhibit a degree of nonuniqueness, the TDEM method included. This lack of unique solutions stems from both inherent resolution limitations and incomplete or inexact data. Thus, for any measured dataset, a range of models typically can be found that adequately fit the data. For most electrical survey methods, equivalence exists between models with equal resistance or integrated resistivity. Thus, for example, a model with a $10-\mathrm{ohm}-\mathrm{m}, 50-\mathrm{m}$ - (164-ft-) thick layer may produce nearly identical observational measurements as does a $25-\mathrm{m}-$ (82-ft-) thick layer of 20-ohm-m resistivity. Additionally, with the TDEM method, there is difficulty resolving resistive layers due to the low induced current densities within the resistive layers as compared to conductive layers.

Appendix 1 contains the measured apparent-resistivity TDEM data at all 16 sites together with the best-fit inverse models. At each station, the central panel shows the best-fit minimum-layer (red) and smooth (blue) inverse models. The left panel shows the forward response (straight lines) overlain upon the measured data for the minimum-layer and smooth model. In most cases, the model response falls within the measured data errors; exceptions occur at the earliest times, where inaccuracies in timing and filtering are noticed, and at the latest times, where incomplete removal of cultural noise can occur.

Interpretation of the TDEM data, as with the AEM data, was based on the electrical resistivity difference between the aquifer materials in $\mathrm{HU} 2,5$, and 7 and the silt and clay in HU 8, 9, and 10. Both minimum-layer and smooth models of the electrical resistivity were entered into a database to be displayed within a 2-D and 3-D environment. 


\section{Interpretation of the Base of Aquifer Elevation}

An interpretation for the location of the top of the base of aquifer (BOA) was completed in a Geographical Information System (GIS) that provided X, Y, and Z coordinates. Prior to interpreting the AEM data, several complementary datasets were included and graphically displayed in 2-D and 3-D GIS environments. Complementary data included test-hole lithology, test-hole geophysical logs (including natural gamma and electrical resistivity), TDEM resistivity models, airborne measurements of the intensity of 60-hertz power-line interference, airborne measurements of the magnetic total-field intensity, airborne photographs, and the 90-m digital elevation model (DEM). Other maps, identifying roads, power lines, pipelines, irrigation canals, towns, and geology, also were used. The AEM inversions were displayed as colored resistivity sections within the GIS environment. The resistivity data were plotted using the same color scale, and all of the datasets were placed in the same projected coordinate system. This allowed the data to be examined at many scales and for data to be iteratively displayed and/or hidden in order to fully examine how the geophysical data interrelate with complementary datasets.

The process of interpretation had the geophysicist, hydrologist, and geologist manually pick locations with elevation on the displayed AEM profile. These locations or "picks" of the BOA (typically top of HU 8, 9, and 10) were then stored in a georeferenced database. The "pick' was made by comparing the resistivity profile from the airborne geophysical survey along a flight line to the known lithology of the area, based on test-hole data and borehole geophysical logs. Using GIS to view all available data at one time in a spatially correct manner imparts a high degree of confidence in the elevation values for the "picks."

Figure 5 is a profile of AEM inversions, TDEM minimumlayer inversions, and test-hole lithology, with the interpretations or "picks" of the top of the confining units HU 8, 9, and 10, along flight line 30030 in the NPNRD. In the area of 2008 flight line 30030, the confining units $\mathrm{HU} 8,9$, and 10 are overlain by HU 2. Each of the interpreted locations or picks of the BOA were compared with the depth of investigation (DOI) metric for that AEM sounding location. A "pick" confidence value, between 1 and -1 , for each location was calculated, with 1 being the highest confidence (picked horizon is well within the depth of investigation of the AEM inverted section) and -1 being the lowest confidence (picked horizon is well below the depth of investigation). This confidence metric was attached to the individual interpreted picks of the elevation of the BOA. The "picks" displayed in figure 5 illustrate the impact of the DOI metric on the "pick" confidence, that in general the deeper the "pick," the lower the "pick" confidence.

Figure 6A shows a profile of the AEM inversions and test-hole lithology, with the interpretations or "picks" of the top of the confining units HU 8 and 9, along 2008 flight line 40070 in the SPNRD. As in figure 5, the "picks" have a "pick" confidence value assigned. The impact of the DOI metric is also apparent in the decrease in the "pick" confidence with depth in the SPNRD. The picks in figure 6 also illustrate the complexity of the AEM sections in areas of HU 5 overlaying confining units HU 8 and 9.

One of the key factors for picking the top of the confining units HU 8, 9 and 10 involves understanding the three-dimensional relationships of the aquifer and the confining unit. By utilizing the georeferenced data together in a GIS, relations can be better exploited and confidence in the picking of the confining unit can be increased. Figure 7 shows a three-dimensional fence diagram of the AEM inversions and TDEM minimum-layer inversions with the interpretations or "picks" of the top of the confining units HU 8, 9, and 10 looking to the west (up the North Platte River) from the far eastern end of the AEM survey area in the NPNRD. As in figures 5 and 6 , figure 7 illustrates the effect of the DOI metric on the deeper "picks." It is important to note that the addition of the TDEM minimum-layer inversions improves ability to pick the areas at the limit of the DOI metric. Important features include the current North Platte River canal and the shape of the valley as traced to the west.

The process of picking confining units $\mathrm{HU} 8,9$, and 10 from the AEM inversions was carried out along the flight lines in both the NPNRD and the SPNRD. Databases of "picks" were developed with the corresponding "pick" confidence based on the DOI metric for both the NPNRD and the SPNRD. Figure $8 A$ is a map of the location and depth of the picks in both the NPRND and the SPNRD. The inset shows an enlargement of an area of block flights near Morrill, Nebr., within the NPNRD. Blue indicates the deepest picks in the range of 125 to $140 \mathrm{~m}$ (about 410 to $460 \mathrm{ft}$ ). The map illustrates the presence of paleochannels within the block flight areas as well as the deeper sections north of Bridgeport, Nebr., and in the areas of Kimball, Nebr. Figure $8 B$ is a map of "pick" confidence for the NPNRD and the SPNRD. As in the profile (figs. 5 and 6 ) and in the three-dimensional fence diagram (fig. 7), the effect of the DOI metric on the confidence of the "picks" can be observed in the deeper paleochannels in the block flights near Morrill, Nebr., north of Bridgeport, Nebr., and the area around Kimball, Nebr. This information was used in the development of the BOA maps described in the following section.

\section{Redefining the Base of Aquifer Contours}

Original COHYST 1:250,000-scale BOA contours were interpolated from the BOA elevations determined from data for existing wells and test holes at discrete points (Luckey and Cannia, 2006). All elevations were referenced to the National Geodetic Vertical Datum of 1929 (NGVD29). The AEM-refined BOA contours are projected as feet above the NGVD29 datum. Point locations of BOA elevations were picked from AEM data and borehole geophysical logs confirming the base unit. These locations were exported to Esri shapefile format to provide more detailed elevation control in redefining the BOA contours. Point locations from existing wells and test holes (Luckey and Cannia, 2006) used 

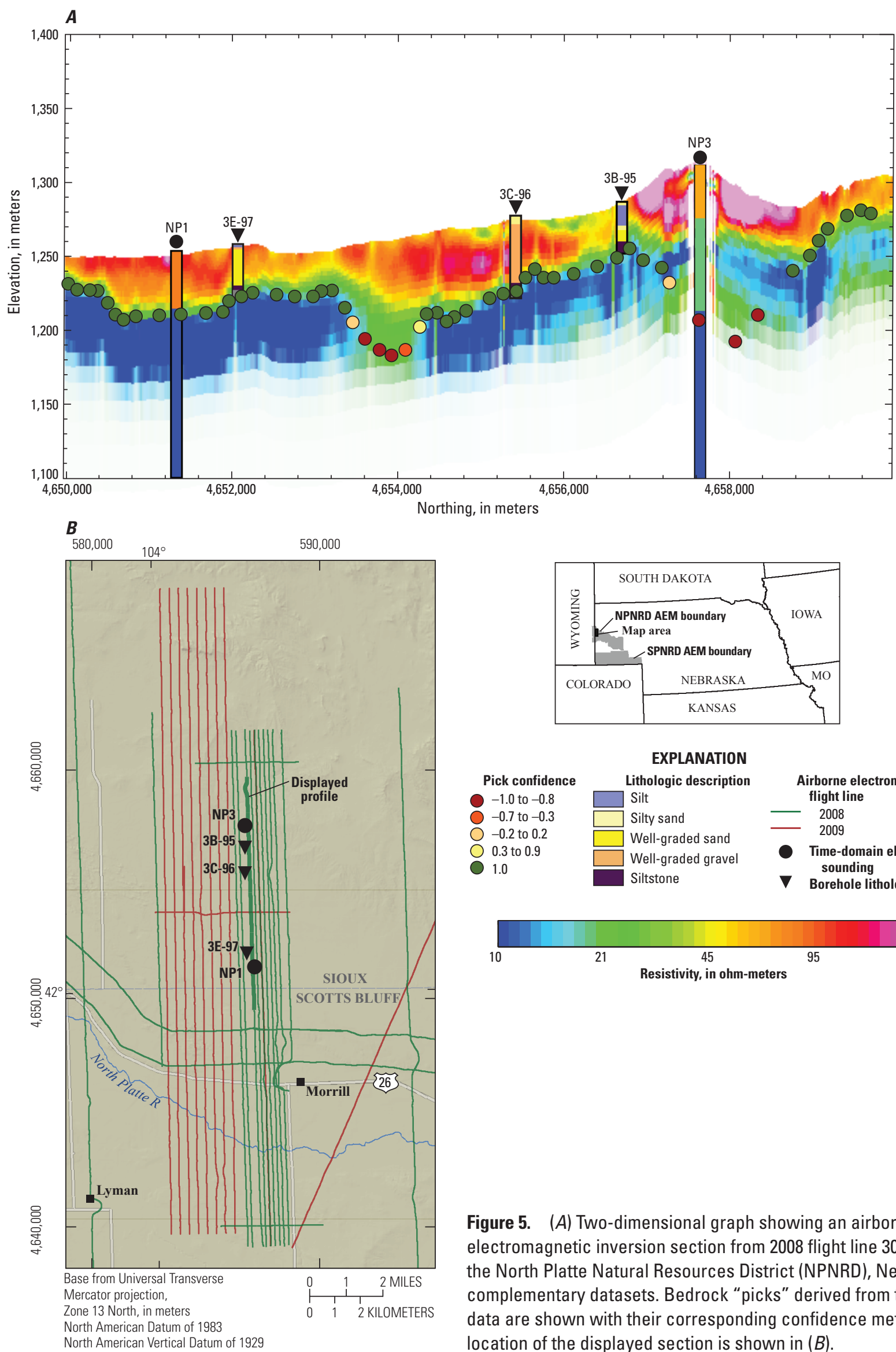

EXPLANATION

Pick confidence Lithologic description Airborne electromagnetic

-1.0 to -0.8

-0.7 to -0.3

- -0.2 to 0.2

0.3 to 0.9

1.0

Silt

flight line

Silty sand

Well-graded sand

Well-graded gravel

Siltstone

2008

2009

- Time-domain electromagn sounding

\ Borehole lithologic log

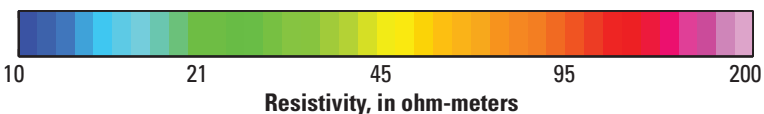

Figure 5. (A) Two-dimensional graph showing an airborne electromagnetic inversion section from 2008 flight line 30030 in the North Platte Natural Resources District (NPNRD), Nebr., with complementary datasets. Bedrock "picks" derived from these data are shown with their corresponding confidence metric. The location of the displayed section is shown in $(B)$. 

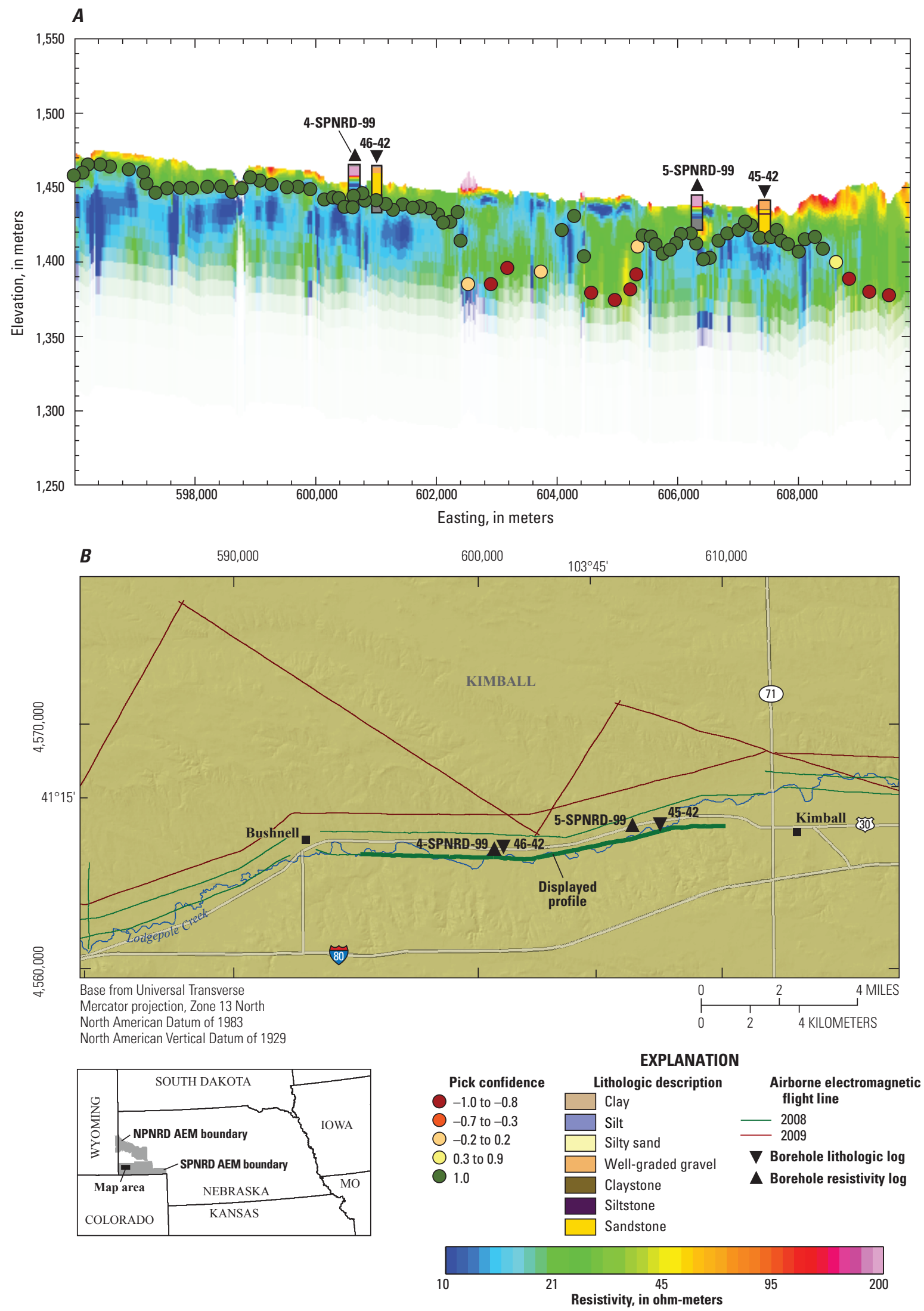

Figure 6. (A) Two-dimensional graph showing an airborne electromagnetic inversion section from 2008 flight line 40070 in the South Platte Natural Resources District (SPNRD), Nebr., with complementary datasets. Bedrock "picks" derived from these data are shown with their corresponding confidence metric. The location of the displayed section is shown in $(B)$. 


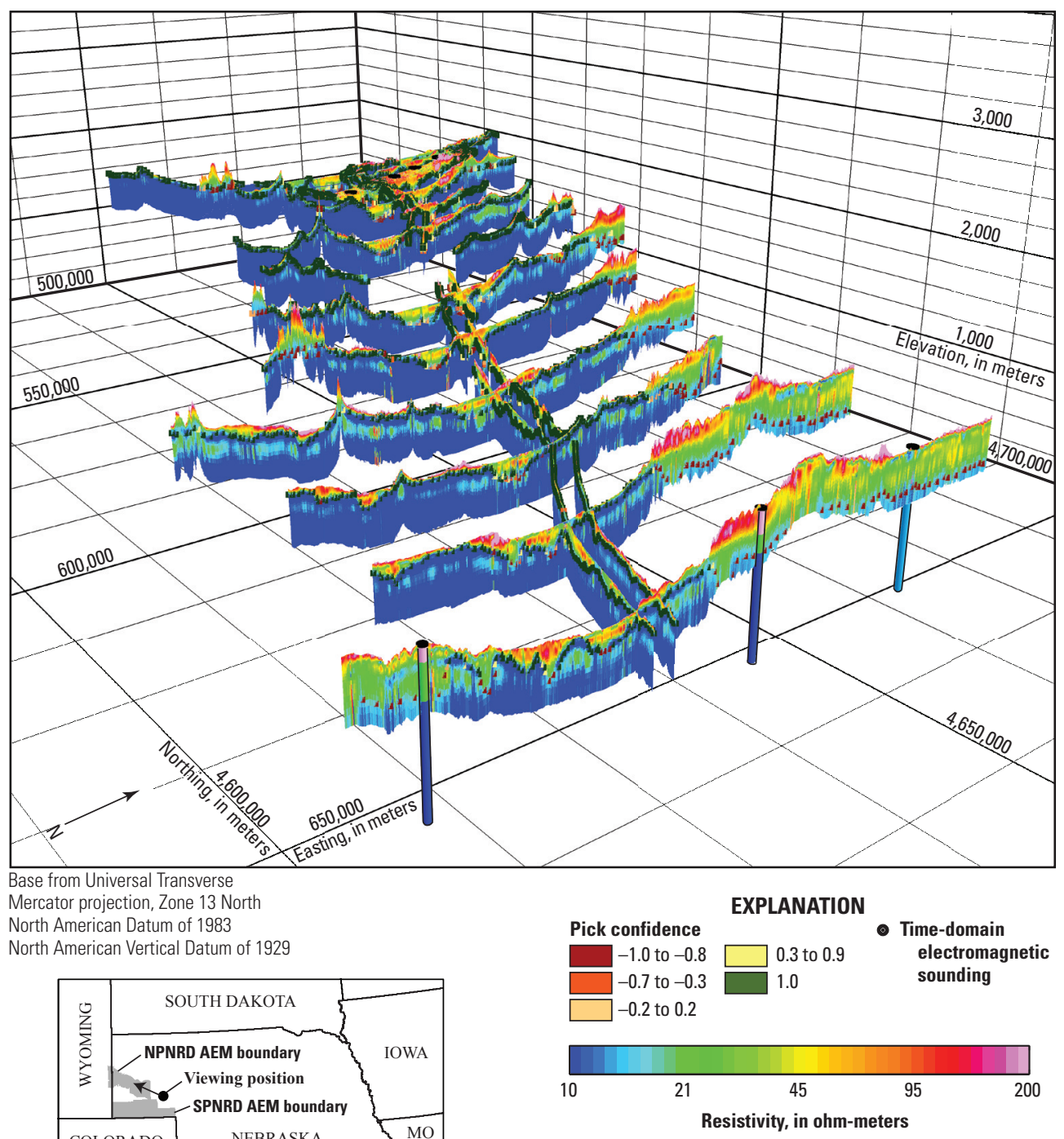

Figure 7. Three-dimensional fence diagram showing inverted time-domain electromagnetic soundings and airborne electromagnetic inversion sections from 2008 flight lines of the North Platte Natural Resources District, Nebr. Bedrock "picks" derived from these data, as well as other complementary data, are shown with the corresponding confidence metric.

in the original interpolation of the BOA were used again as elevation control in the contour refinement. Additional point locations for BOA elevation were provided from the TDEM surveys conducted at a network of locations coinciding with AEM flight paths. The TDEM surveys were used to identify those BOA elevations where the thickness of overburden was greater than the AEM DOI metric.

The COHYST-BOA contours were originally drawn at a $100-\mathrm{ft}(30.48-\mathrm{m})$ interval. Preliminary, 50-ft (15.24-m) contours were generated using the ArcGIS application Topogridtool (Esri, 2011), to interpolate the original contour surface and recontour the data to $50-\mathrm{ft}(15.24-\mathrm{m})$ intervals (Worboys, 1995). The database of "picks" from the interpretation of the new BOA elevation was used to create the new BOA contours. The new BOA contours for this report are a modification of the COHYST tops of HUs 8,9 , and 10 , which collectively are known as a confining unit where they are in contact with the primary aquifer, which is made up of HUs 2, 5, and 7. The confining unit is present throughout the study area. All Esri Arc files of the new BOA are included in Appendix 3.

The "picks" for the new BOA were combined with original COHYST BOA contours into a single GIS "project." The COHYST-BOA was modified to match the DEM for this project, which eliminated any BOA elevations above ground surface. The integration of geophysical data into the contouring process facilitates a more continuous and spatially comprehensive view of the hydrogeologic framework. This supports the BOA interpretation at a smaller contour interval $(50 \mathrm{ft}$, or $15.24 \mathrm{~m})$ than was reasonable when the original COHYST BOA contours $(100 \mathrm{ft}$, or $30.48 \mathrm{~m})$ were drawn. 

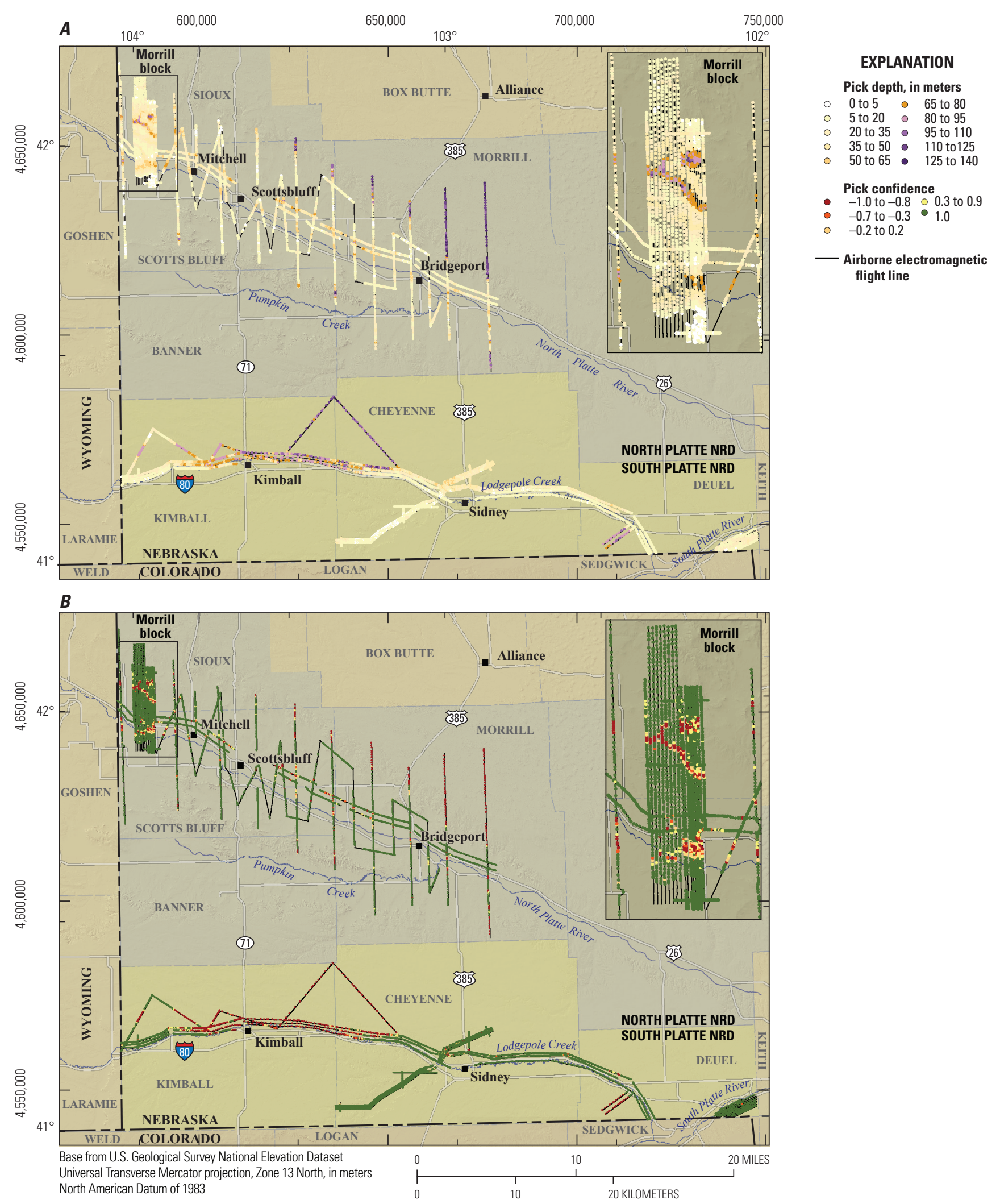

Figure 8. Maps of $(A)$ North and $(B)$ South Platte Natural Resource Districts, Nebr., showing the depth-to-bedrock picks from the helicopter electromagnetic inversions and the pick confidence metric. The inset shows an enlargement of the Morrill, Nebr., block. 
The new preliminary set of 50-foot (15.24-m) BOA contours were redefined using the point locations of base of aquifer elevation. The redefined contours were compared with land-surface elevation as a consistency check. Where the BOA intersects land surface, the contours were reshaped to follow the 90-m DEM. This was done to correct areas where the BOA exceeded the 90-m DEM. To facilitate comparison between the original COHYST contours and the redefined AEM-TDEM contours, the contours were interpolated to raster surfaces, again using the ArcGIS application, Topogridtool (Esri, 2011). An estimate of aquifer thickness was created from the subtraction of the new 90-m BOA surface from the 90-m DEM.

\section{New Base of Aquifer Contours}

\section{Comparison of Airborne Electromagnetic to Cooperative Hydrology Study Base of Aquifer Contours}

The differences in contours between the new BOA and the COHYST BOA for two selected areas in the NPNRD are shown in figure 9 . Figure $9 A$ shows an area of traditional block flight and locations of supporting data from boreholes, TDEM soundings, and bedrock maps near the town of Morrill, Nebr. The dense control enables drawing a refined map that illustrates sharp, deep paleochannels and other features that can be interpolated only generally in sections of the mapped area which have less control. The map (fig. 9B) for an area near the town of Minatare, Nebr., illustrates the use of reconnaissance lines in creating a new BOA map. While the reconnaissance lines do not have the density of control that the block flights have, they do allow delineation of sharp paleovalleys in the BOA surface.

The new BOA contours similarly are compared to COHYST BOA contours for two selected areas in the SPNRD (fig. 10). An area near the town of Sidney, Nebr., shown in figure $10 B$, shows all of the features described for the area near Morrill, Nebr. (fig. 9A). As before, the dense control yields a refined map that illustrates sharp, deep paleochannels, large BOA elevation highs, and relatively well-defined features that can only be interpolated in other sections of the map which have less control. An area near the town of Dix, Nebr. (fig. 10A), illustrates the use of reconnaissance lines in creating a new BOA map. As before, while the reconnaissance lines do not have the density or control that the block flights have, they do allow for the delineation of sharp paleovalleys in the BOA surface.

\section{Effect of New Base of Aquifer on the Hydrogeologic Framework}

Airborne electromagnetic data in combination with complementary datasets allow interpretation that supports refined characterization of the base of aquifer and integration with the hydrogeologic framework. This section of the report discusses BOA topography and the thickness change of the primary aquifer after comparing the new BOA (generated from the use of the AEM data) to the COHYST-BOA (generated from regional datasets; Luckey and Cannia, 2006). Elevation surfaces for the DEM, 1995 COHYST water table, COHYST $\mathrm{BOA}$, and the new BOA were drawn for all the contour maps through a gridding process in ArcGIS (Esri, 2011). Sections were plotted to facilitate comparison between datasets. Elevations were extracted from the DEM, the water table, the older COHYST BOA, and the new BOA along the flight lines.

A hydrogeologic section taken along flight line L20130, located east of Bridgeport, Nebr., is shown in figure $11 \mathrm{~A}$. The profile line is oriented south to north and crosses the North Platte River. It extends from the north edge of the Cheyenne Tableland to the Morrill Tableland. The line is $50 \mathrm{~km}(31 \mathrm{mi})$ long and crosses paleochannels in HU 2 that generally run parallel to the river and are incised into HUs 8 and 9. The interpreted surfaces in the profile are the land surfaces as defined by the land surface DEM, 1995 COHYST water table, the original 1995 COHYST BOA, and the new BOA.

A comparison of the topography of the new BOA with that of the original COHYST BOA illustrates the difference in using regional datasets, test holes, and surficial geologic maps to create a surface in contrast to the more detailed surface derived through the addition of AEM data and application of the methodology presented in this report. The 1995 COHYST map depicts paleochannels incised into the confining unit in a very general way due to the low density of data points used to provide subsurface elevation control. The new BOA depicts a more accurate illustration of the base topography because the density of data points provides a nearly continuous profile of elevation.

The buried topography of the BOA controls the amount of water in storage and the groundwater flow direction. The COHYST BOA combined with the 1995 water table illustrates there is little in the way of BOA elevation change that intercepts the water table. The aquifer is saturated and continuous with the exception of the area north of the river, where high elevation of the BOA separates the principal aquifer from the tableland and river valley, creating a barrier to flow with the North Platte River.

The water table, in combination with the new BOA, illustrates the amount of saturated thickness and a much more complicated system for groundwater flow. At several locations along the profile, relatively high elevations of the BOA cause barriers or constrictions to groundwater flow from the tableland on both the north and south sides of the river. Those barriers and constrictions have a direct bearing on whether a stream is connected hydrologically to the principal aquifer.

Profile L60080 (fig. 11B) uses the same combination of surfaces to depict the differences between the 1995 COHYST $\mathrm{BOA}$ and new BOA and the relation to the hydrogeology of the area. This profile is north of Sidney, Nebr., in the Lodgepole Creek area and is $5.5 \mathrm{~km}$ (3.4 mi) long. The profile runs along the southern edge of the Cheyenne Tableland, from southwest to northeast and perpendicular to Lodgepole Creek.

For profile L60080, the change from the COHYST BOA and the new BOA is more pronounced than the previously discussed profile perpendicular to the North Platte River. Here the COHYST contours were drawn with fewer data (control) 


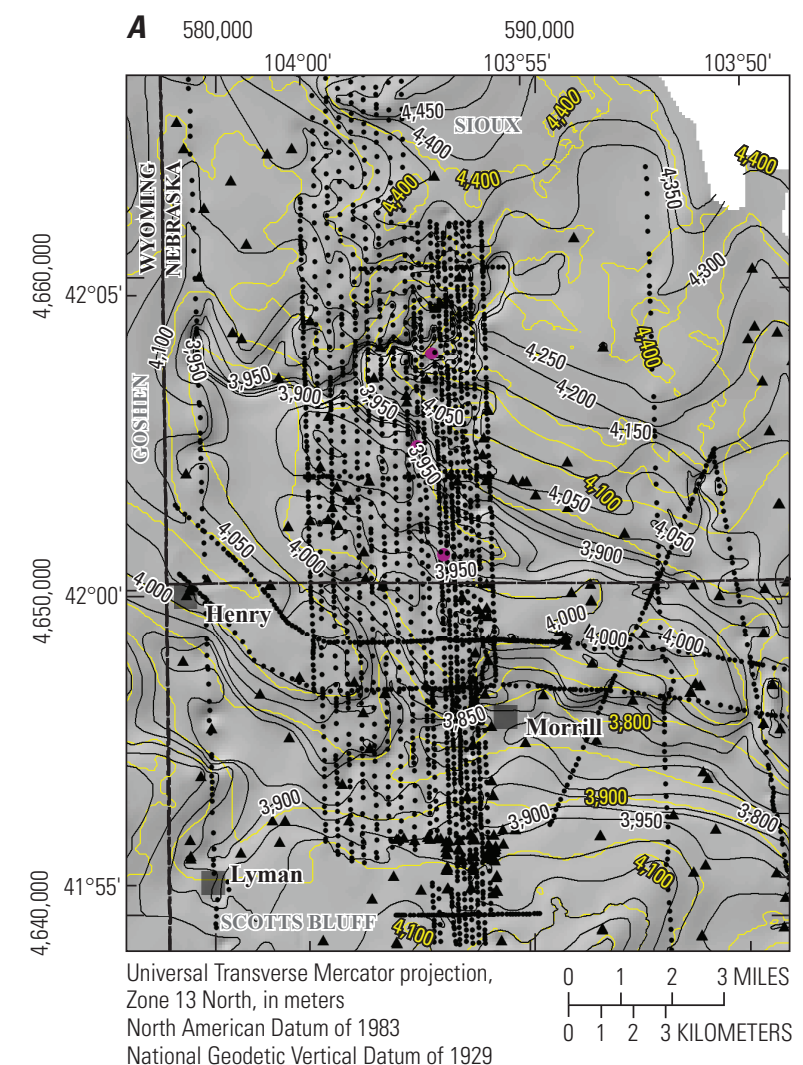

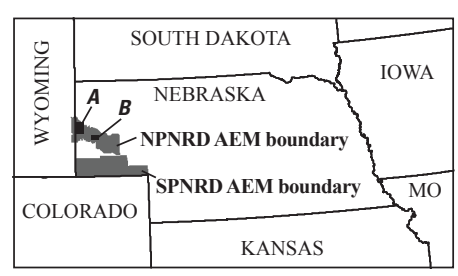

\section{EXPLANATION}

Base of aquifer elevation control data

- Airborne electromagnetic "pick"

- Cooperative Hydrology Study (COHYST) control point

- Time-domain electromagnetic sounding

Base of aquifer contours, elevation in feet

Base of aquifer (this study) COHYST base of aquifer

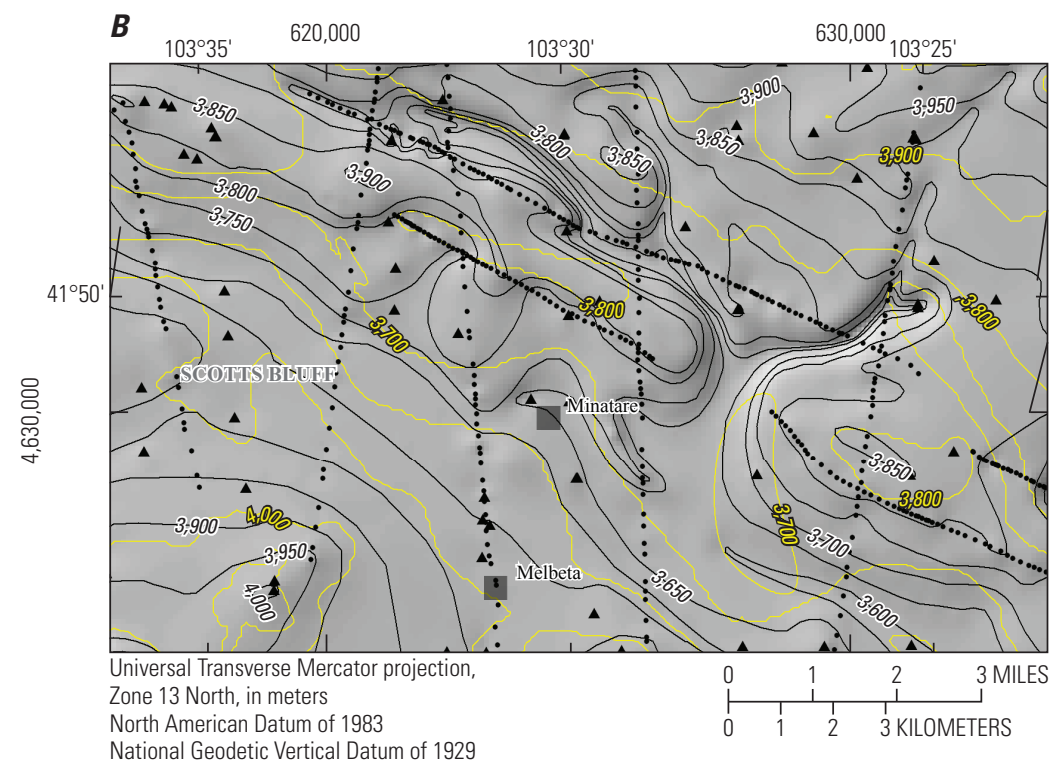

Figure 9. Examples of the new base of aquifer contours within the North Platte Natural Resources District. Location $(A)$ is near Morrill, Nebr., and $(B)$ is near Minatare, Nebr.

points, leading to a very smooth interpreted surface when compared to the newly interpreted BOA surface derived from the AEM interpretation combined with existing data points. The new BOA reveals a more complex topographic surface that, when combined with the water-table map, yields a new configuration of the principal aquifer. The principal aquifer has reduced saturated thickness compared to that of the COHYST version, and in some locations, there is no saturated thickness in the new interpretation. Saturated sections are dissected by high elevations of the new BOA and are separated hydrologically from Lodgepole Creek in that area.

The thickness of the primary aquifer material has been redefined and redistributed throughout the project area. The effect of the new BOA compared to that of the COHYST BOA 

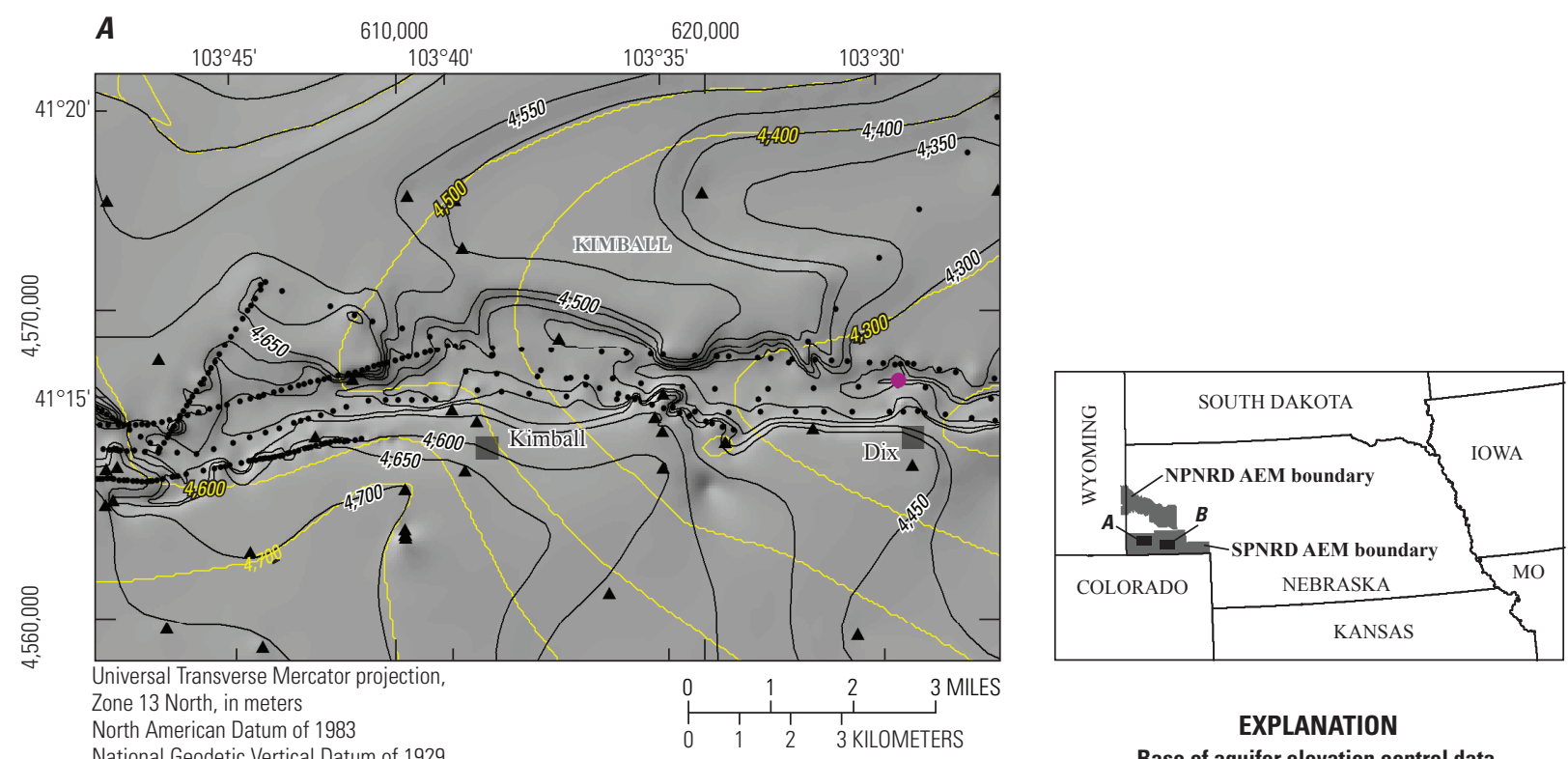

National Geodetic Vertical Datum of 1929

\section{EXPLANATION}

Base of aquifer elevation control data

- Airborne electromagnetic "pick"

- Cooperative Hydrology Study (COHYST) control point

- Time-domain electromagnetic sounding

Base of aquifer contours, elevation in feet

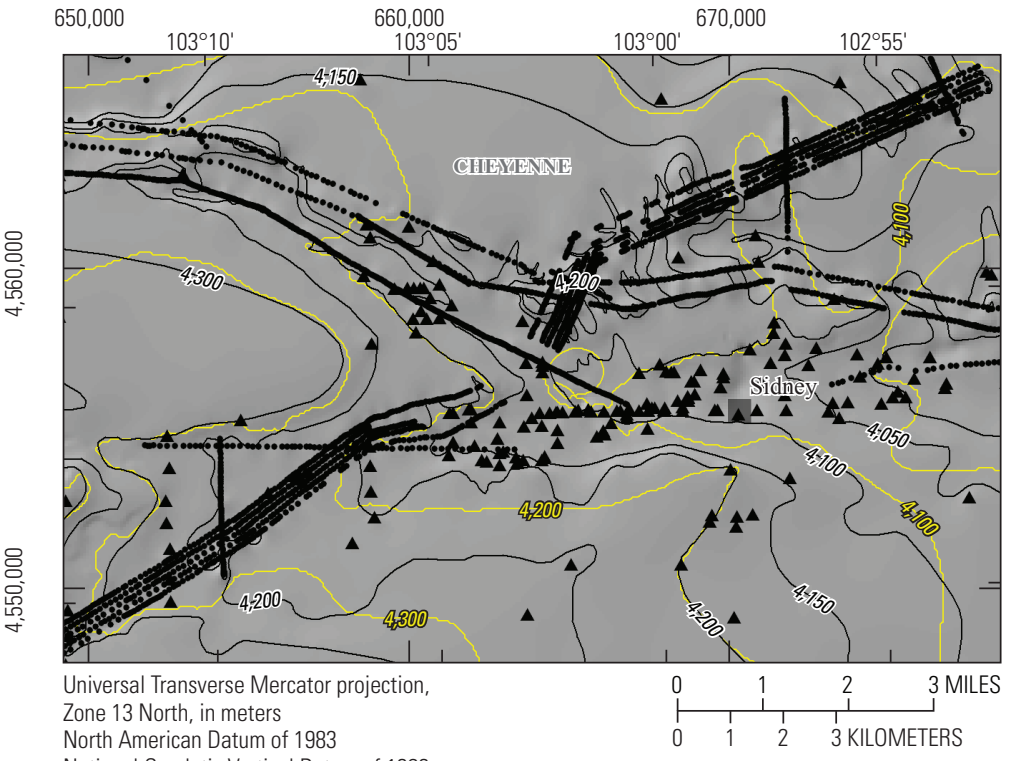

- Base of aquifer (this study) COHYST base of aquifer

Figure 10. Examples of the new base of aquifer contours within the South Platte Natural Resources District.

Location $(A)$ is near Dix, Nebr., and $(B)$ is near Sidney, Nebr.

is illustrated in the maps of figures 12 through 15. Thickness of the primary COHYST aquifer material was calculated by subtracting the elevation of the COHYST BOA from that of the DEM, and then following the same process for the new BOA to create the new BOA primary aquifer thickness. The COHYST primary aquifer thickness was then subtracted from the new BOA primary aquifer thickness to create a map of the change in total aquifer thickness.

The map of the thickness change of the primary aquifer within NPNRD between the new BOA and the COHYST BOA (fig. 12) reveals that most of the calculated thickness change has taken place in the Morrill Tableland (in Morrill County) with maximum increases in thickness of approximately $400 \mathrm{ft}$
(122 m). [Because previously published datasets from the area were produced in English units (also called Imperial or footmile-pound units), those units will be used (with SI units in parentheses) in the following discussion of effects of the new maps on the hydrogeologic framework. This is the reverse of the primary position of SI units through most of this report.] The Morrill Tableland area also has the fewest data points to provide control for the new BOA. Directly south of that area, the North Platte valley has the greatest density of data points and therefore offers the best representation of the redefinition of aquifer thickness. Changes in thickness range from +200 to $-200 \mathrm{ft}(+61$ to $-61 \mathrm{~m})$ in that area. Figure 13 shows a detailed section of this map showing changes near Morrill (fig. 13A) 

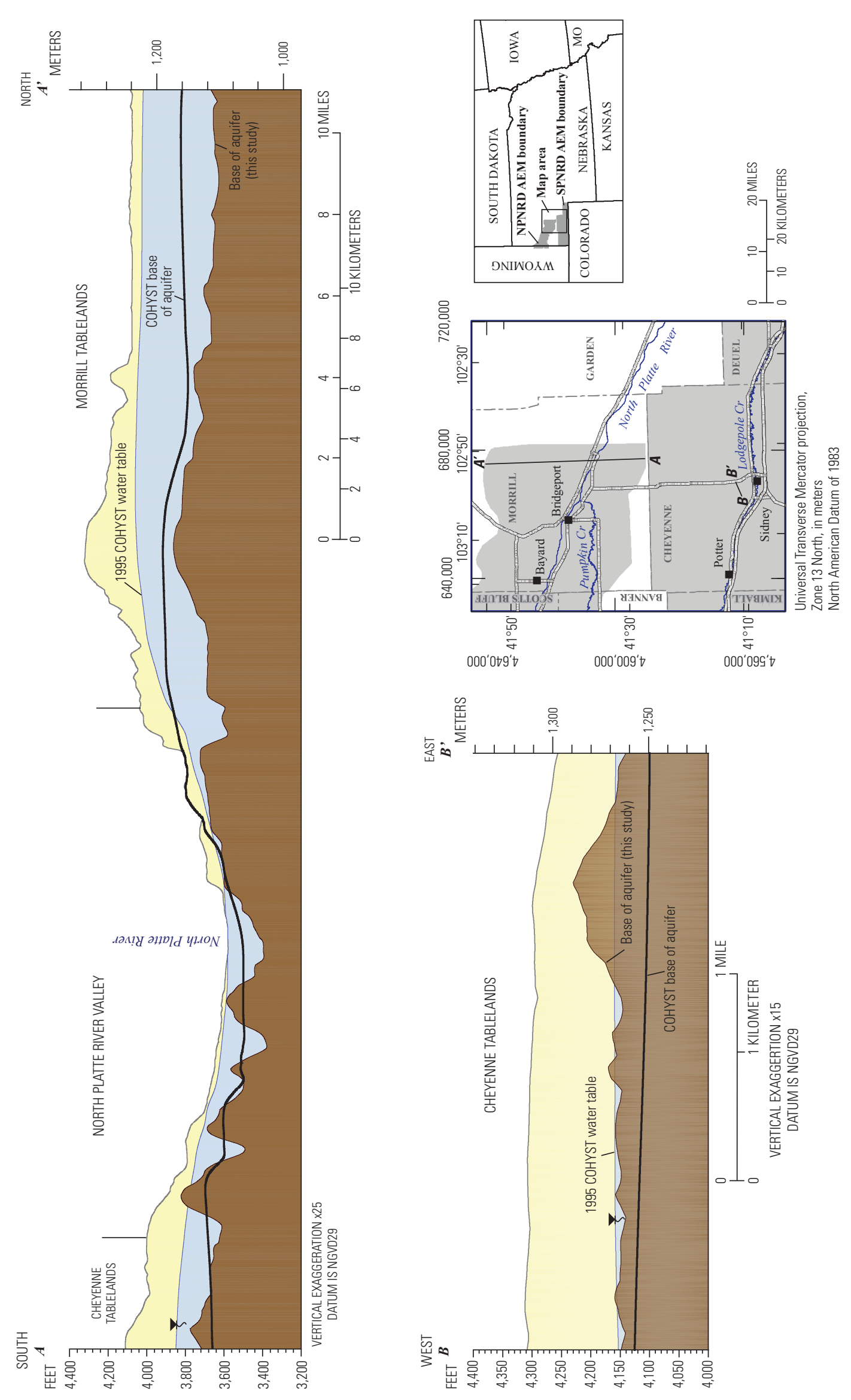

言

흥

응 은

곻ํㅎㅎ

종흐

离范

吾

ठํ

능

$\bar{c}$

Ð

든

क्षे

일

ํㅡㄹ

త

宽焉

$\overbrace{\overline{2}}^{\frac{\pi}{0}}$

帝

坣

क्षे

함 중 ?

\&

중

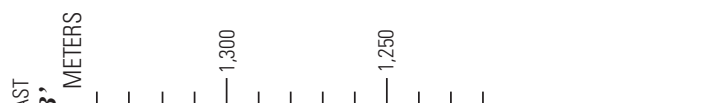

总

के 응

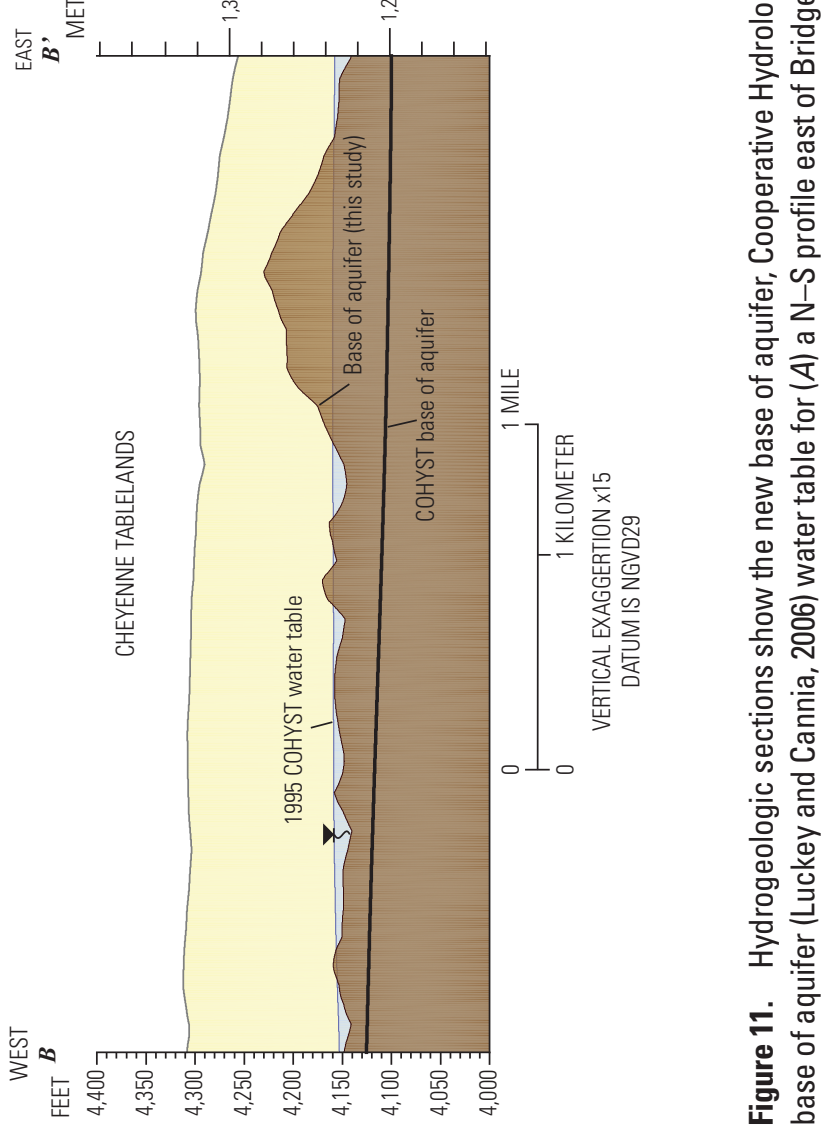



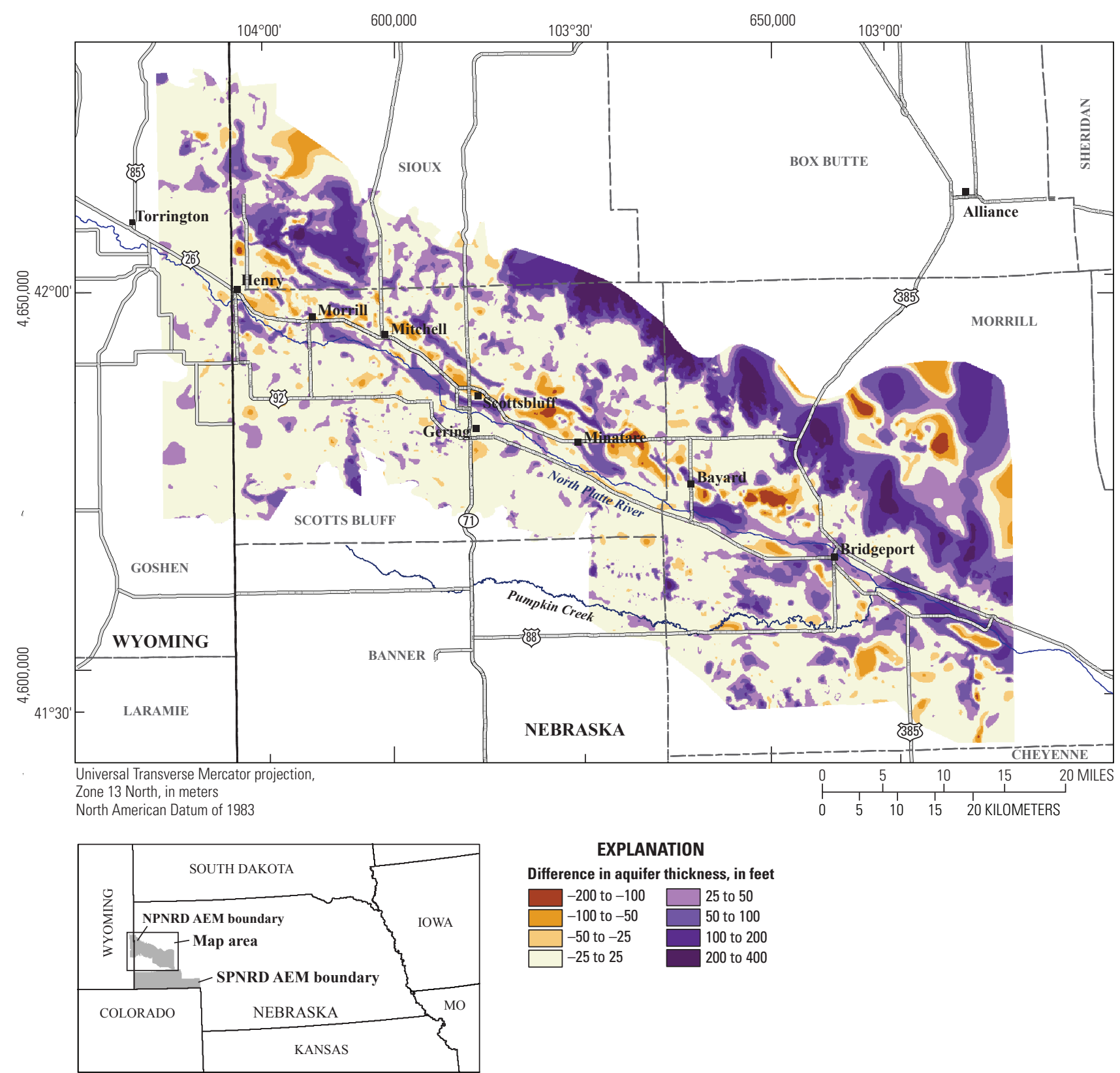

EXPLANATION

Difference in aquifer thickness, in feet

\begin{tabular}{|c|c|}
\hline-200 to -100 & 25 to 50 \\
\hline-100 to -50 & 50 to 100 \\
\hline-50 to -25 & 100 to 200 \\
\hline-25 to 25 & 200 to 400 \\
\hline
\end{tabular}

Figure 12. Changes in thickness of the primary aquifer in the North Platte Natural Resources District, Nebr., between the new base of aquifer and the Cooperative Hydrology Study base of aquifer (Luckey and Cannia, 2006).

and Minatare (fig. 13B). The area around Morrill has the greatest density of control points because it was flown with the traditional block flight pattern of AEM data collection. It represents the new BOA at a detail most representative of the natural system. In contrast, in the area near Minatare, the reconnaissance-line method of collecting AEM data was used, so that although resulting contours are considered more accurate than those drawn without the AEM data, those contours are not as detailed as contours in the Morrill area.

The map of the thickness change of the primary aquifer within the SPNRD between the new BOA and the COHYST BOA (fig. 14) was calculated using the same methodology as described above and reveals that the majority of the interpreted thickness change has taken place in the Cheyenne Tableland with maximum gains and loss in thickness of approximately $200 \mathrm{ft}(61 \mathrm{~m})$. This area also contains the lowest density of data points to provide control for the new BOA. In contrast, the Lodgepole Creek valley has the greatest density of data points and therefore offers the best representation of redefinition of aquifer thickness. Changes in thickness range from $+200 \mathrm{ft}$ to $-200 \mathrm{ft}(+61$ to $-61 \mathrm{~m})$ along its length. Figure 15 presents a detailed section of this map showing changes near Kimball, Nebr. (fig. 15A), and Sidney, Nebr. (fig. 15B).

The saturated thickness of an aquifer has the most meaning for water-resources managers in the study area. The saturated-thickness map can be used to identify areas in the 


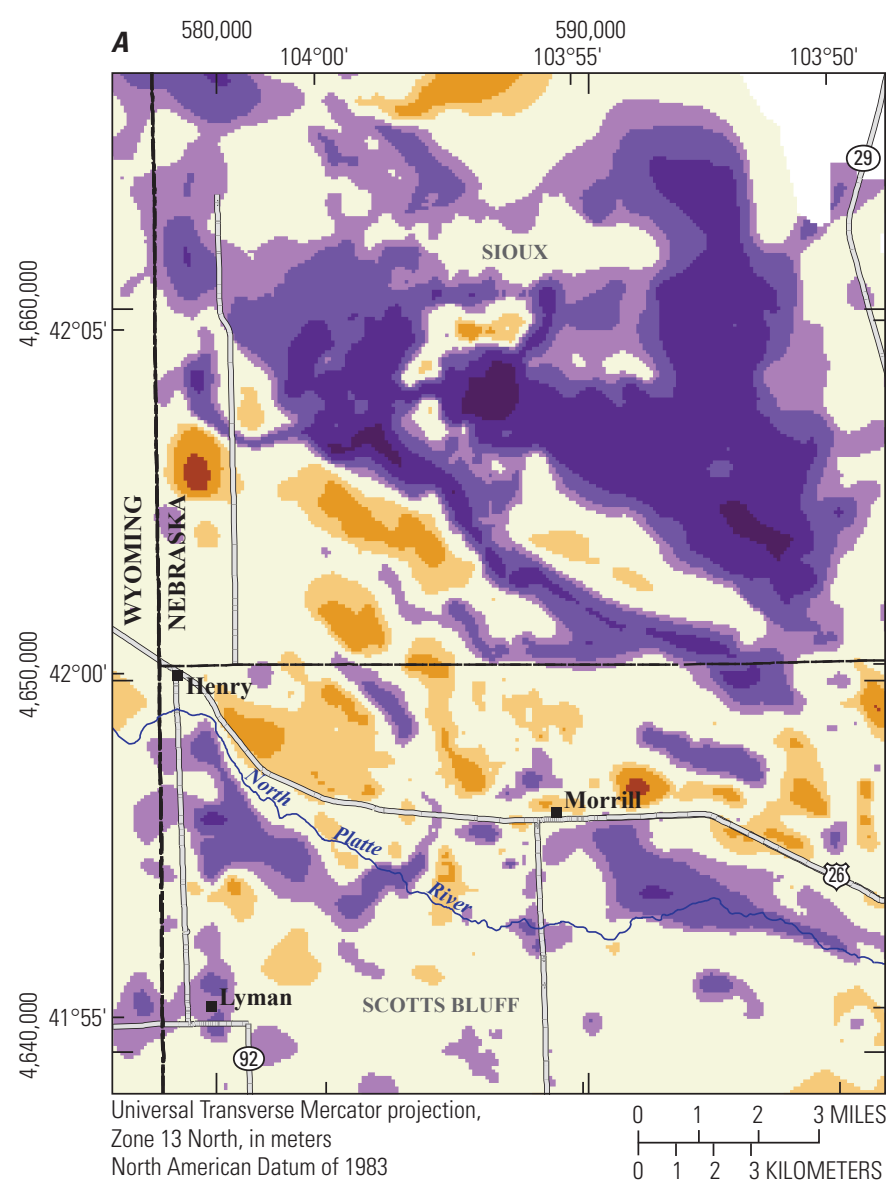

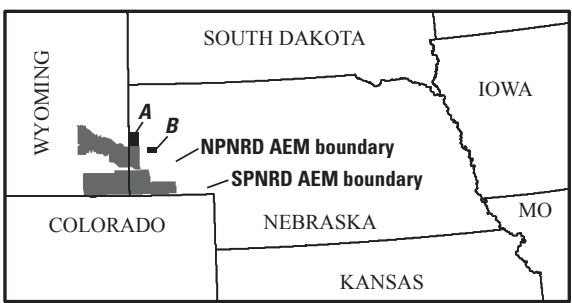

\section{EXPLANATION}

Difference in aquifer thickness, in feet

-200 to $-100 \square 25$ to 50

-100 to $-50 \quad 50$ to 100

-50 to $-25 \square 100$ to 200

-25 to $25 \quad 200$ to 400

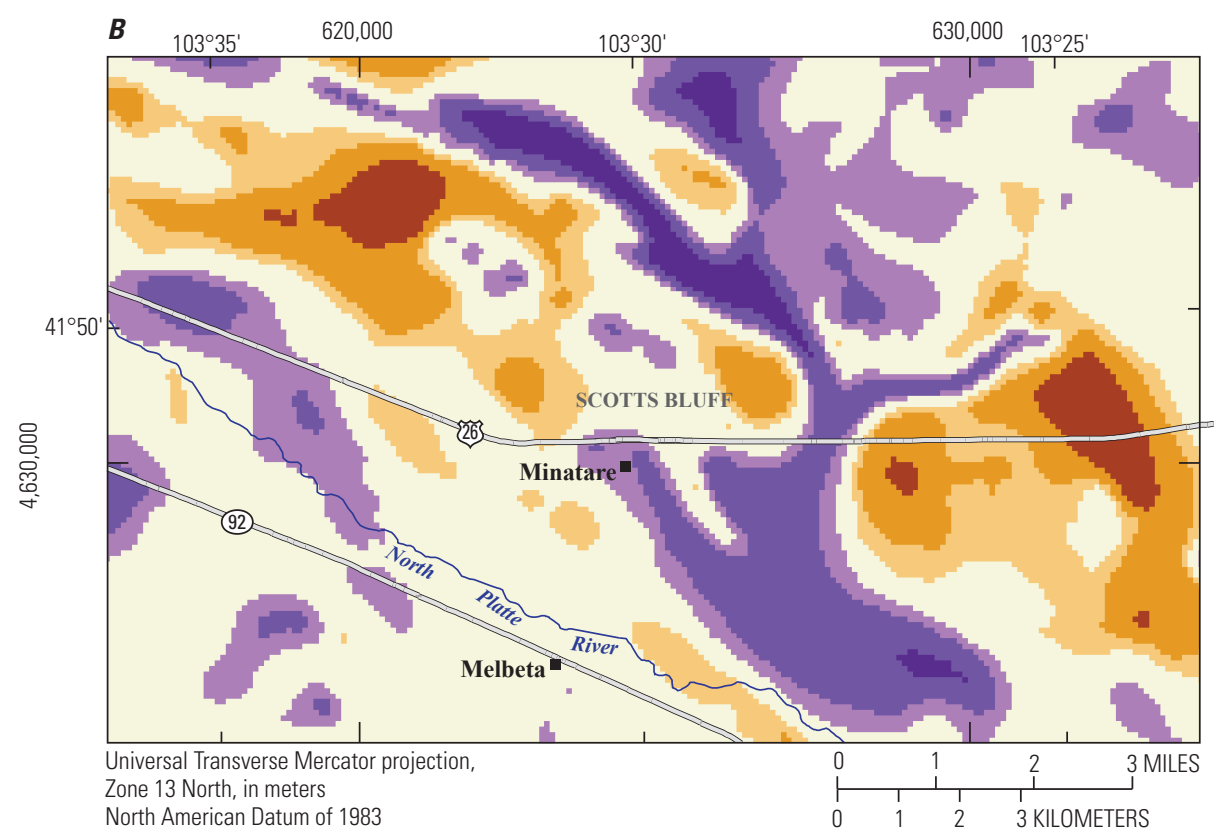

Figure 13. Details of the thickness change of the primary aquifer for selected areas in the North Platte Natural Resources District between the new base of aquifer and the Cooperative Hydrology Study base of aquifer (Luckey and Cannia, 2006). Area $(A)$ is near Morrill, Nebr., and $(B)$ is near Minatare, Nebr. 


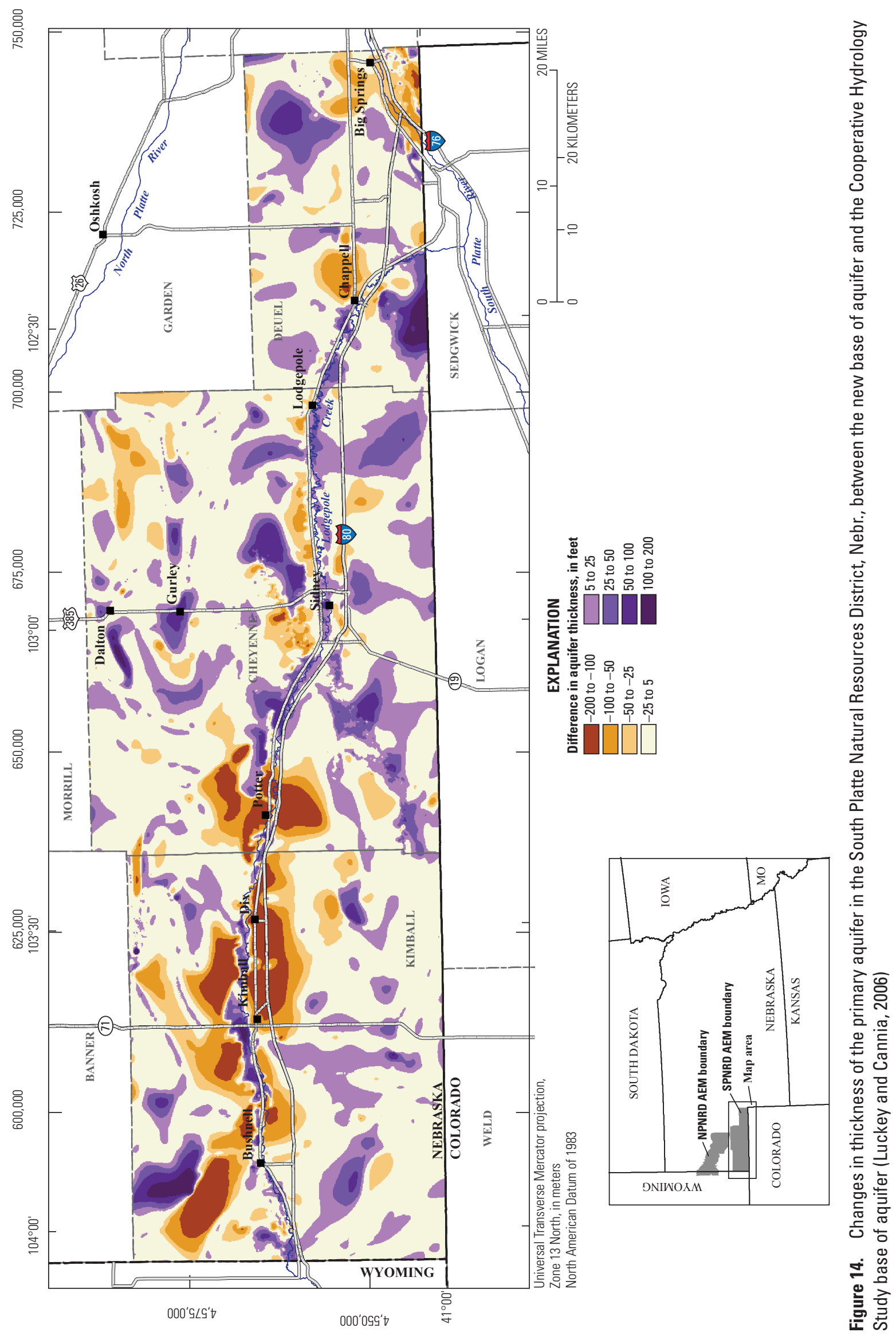




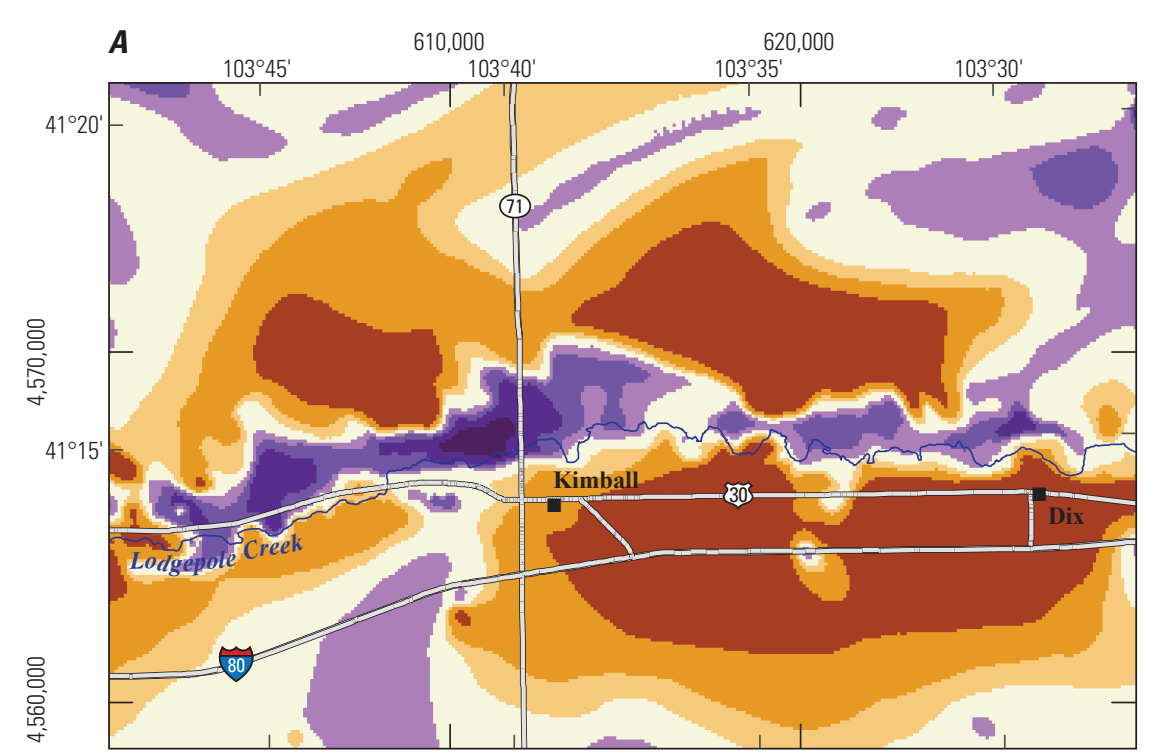

\section{$\boldsymbol{B}$}

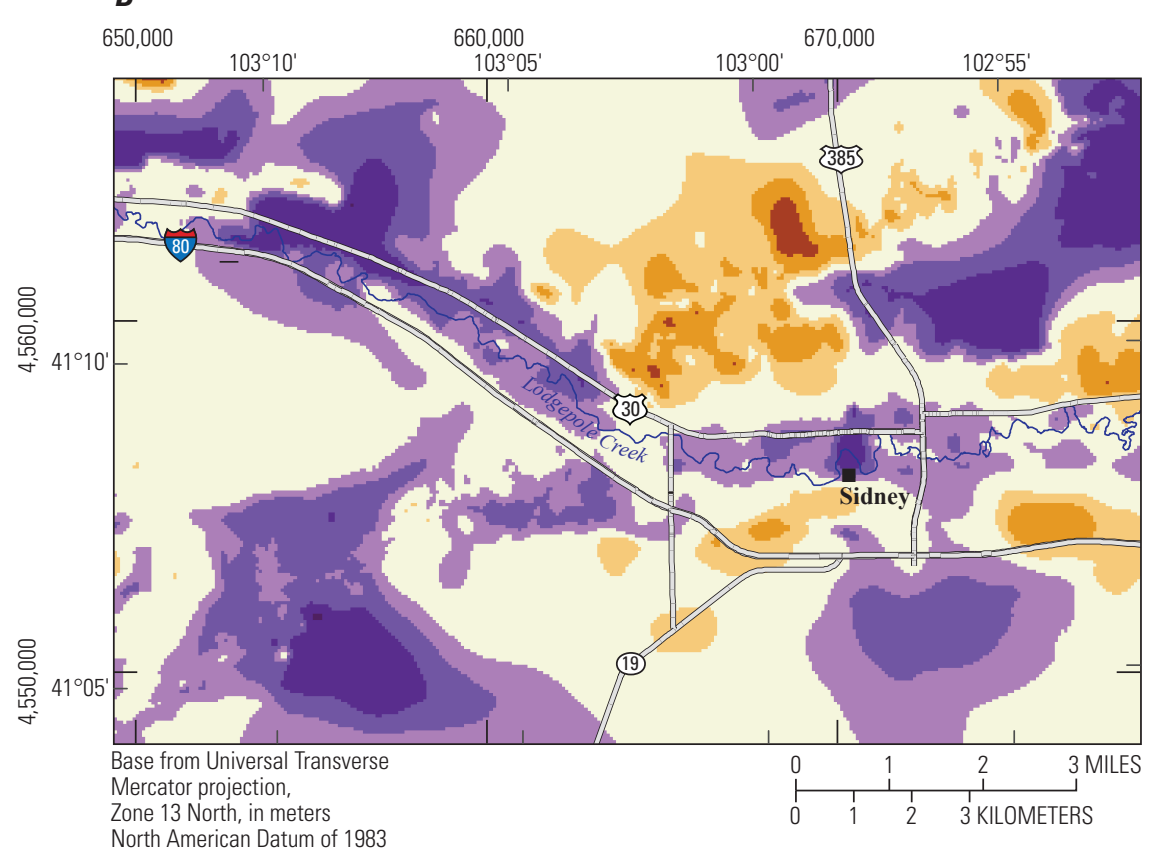

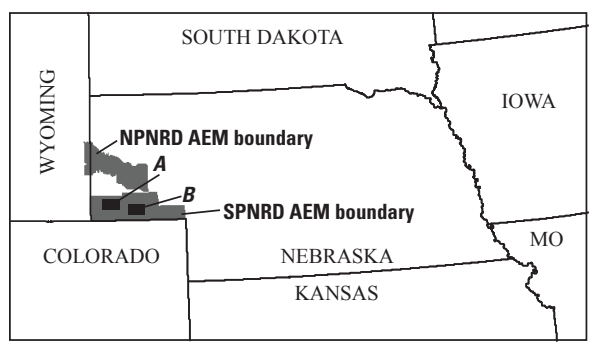

EXPLANATION

Difference in aquifer thickness, in feet

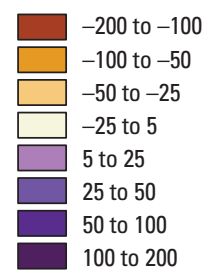

Figure 15. Details of the thickness change of the primary aquifer for selected areas in the South Platte Natural Resources District between the new base of aquifer and the Cooperative Hydrology Study base of aquifer (Luckey and Cannia, 2006). Area $(A)$ is Kimball, Nebr., and $(B)$ is the Sidney, Nebr., area.

natural-resources districts that can be exploited for water development or enhanced through intentional groundwater recharge. The saturated thickness of the aquifer in the NPNRD for both the COHYST BOA and the new BOA is illustrated in figure 16. The new BOA saturated-thickness map is calculated by subtracting the elevation of the new BOA from the 1995 COHYST water table map (fig. 16A). The COHYST saturated thickness map is calculated by subtracting the COHYST BOA from the 1995 COHYST water table map (fig. 16B).

Change in the amount of groundwater in storage for the NPNRD can be estimated by subtracting the COHYST BOA saturated thickness from the new BOA saturated thickness and multiplying the result by an average porosity of 0.23 , the upper limit of porosity used in the NPNRD Groundwater Management Model (S. M. Peterson, oral commun., 2011), which yields a positive net change of approximately $3,710,000$ acre-feet $\left(458,000,000 \mathrm{~m}^{3}\right)$.

The saturated thickness of the SPNRD for both the COHYST BOA and the new BOA is illustrated in fig. 17. The new BOA saturated thickness map is calculated by subtracting the elevation of the new BOA from the 1995 COHYST water table map (fig. 17A). The COHYST saturated thickness map is calculated by subtracting the COHYST BOA from the 1995 COHYST water table map (fig. 17B). Changes in the amount 


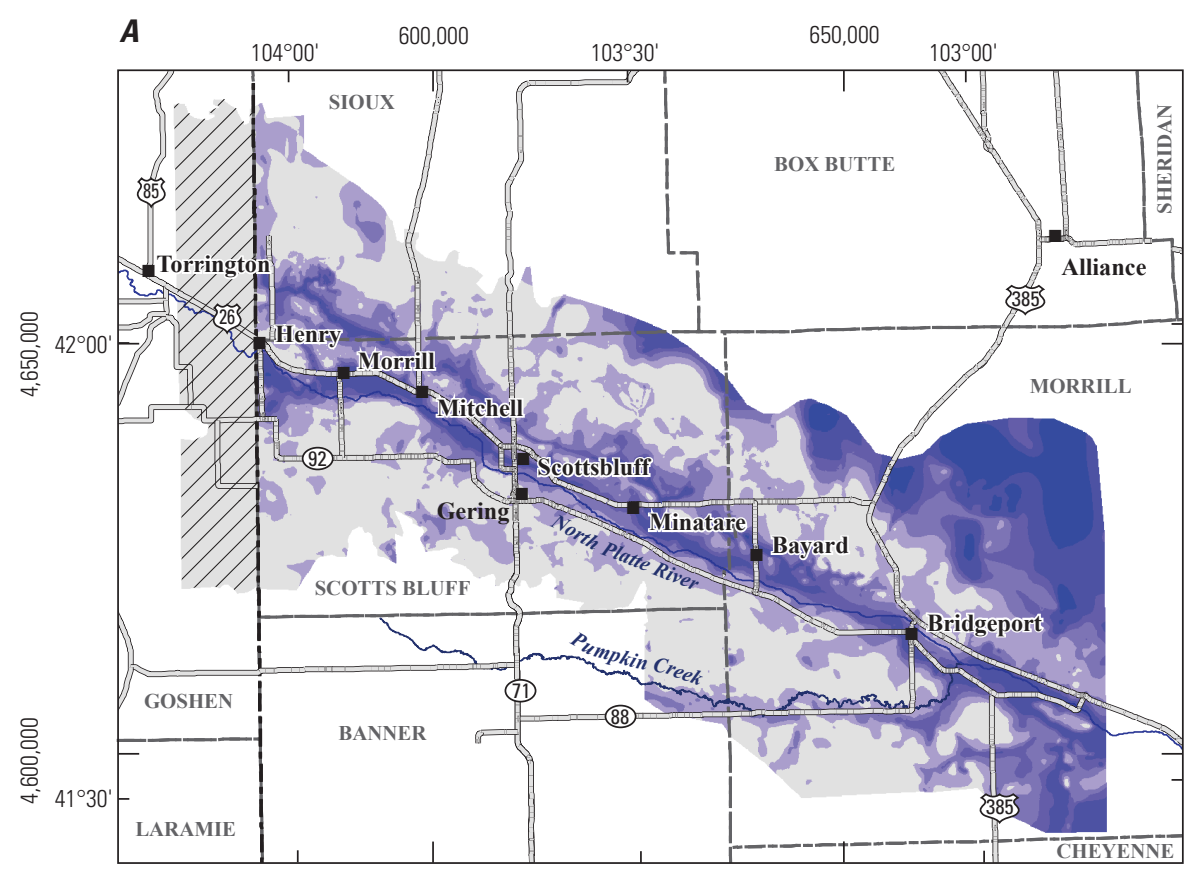

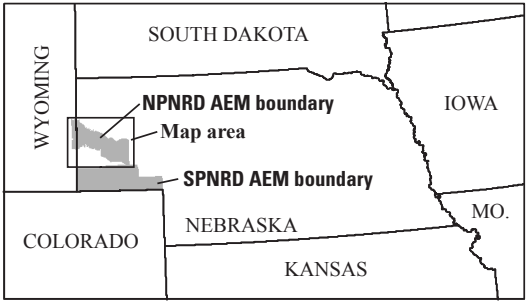

EXPLANATION

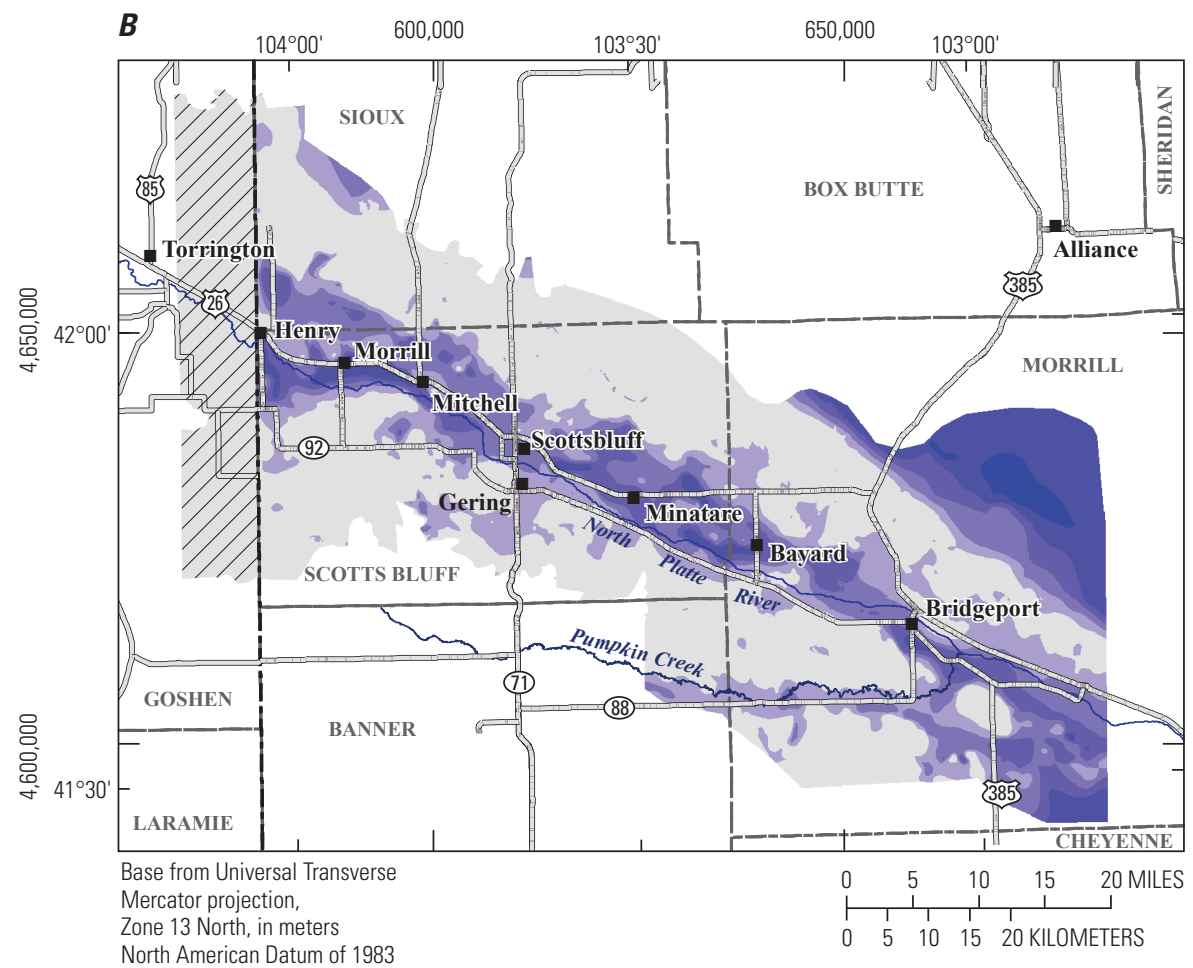

Saturated thickness, in feet

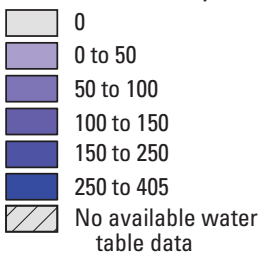

Figure 16. Saturated thickness calculated from the 1995 Cooperative Hydrology Study water table (Luckey and Cannia, 2006) using $(A)$ the new base of aquifer, and $(B)$ the Cooperative Hydrology Study base of aquifer (Luckey and Cannia, 2006) for the North Platte Natural Resources District, Nebr. 

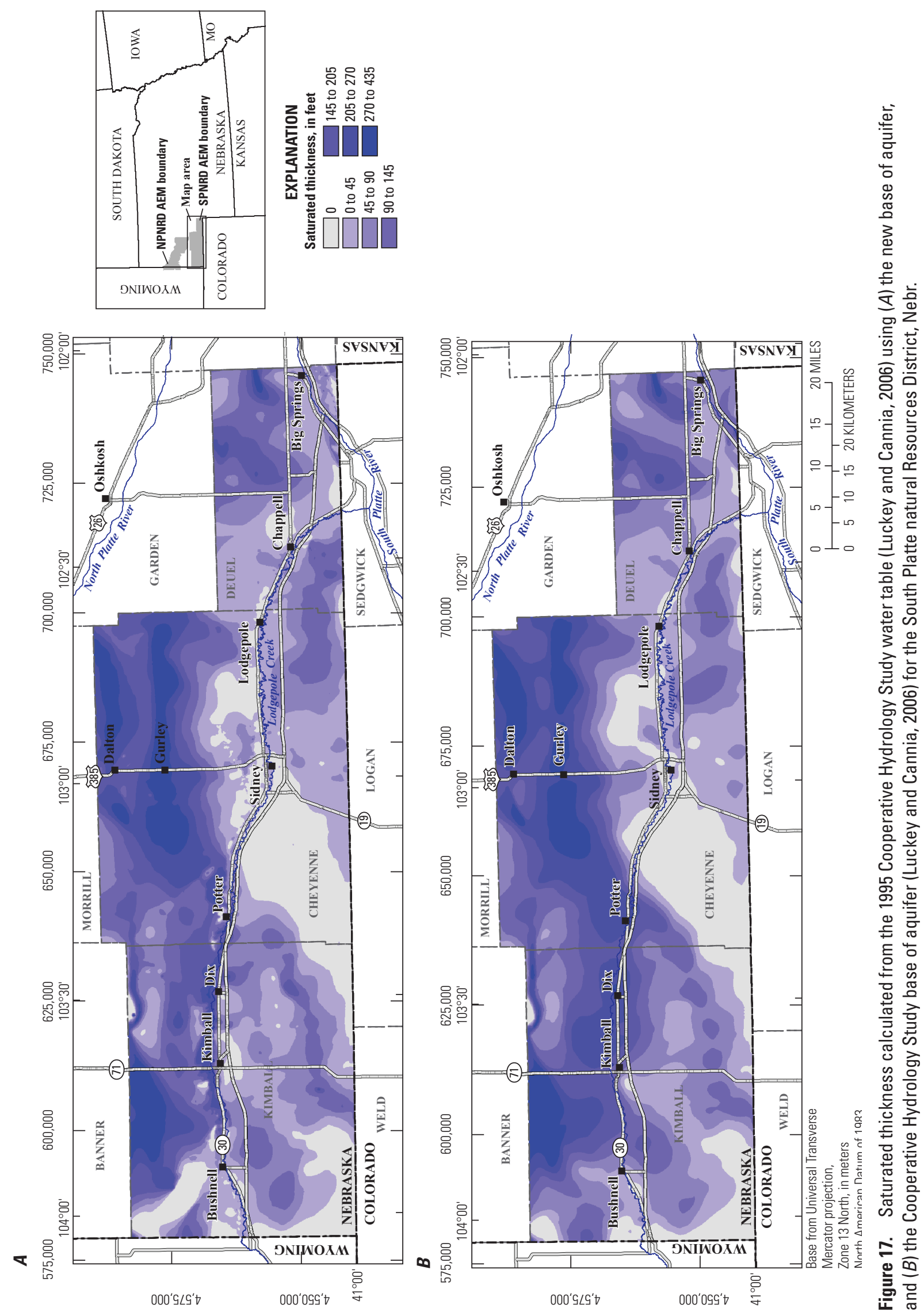
of groundwater in storage for the SPNRD can be estimated by subtracting the COHYST BOA saturated thickness from the new BOA saturated thickness and multiplying the result by an average porosity of 0.23 , the upper limit of porosity used in the NPNRD Groundwater Management Model (S. M. Peterson, oral commun., 2011), which yields a negative net change of approximately $3,290,000$ acre-feet $\left(406,000,000 \mathrm{~m}^{3}\right)$.

\section{Suggestions for Similar Studies}

Effective design and implementation of airborne electromagnetic geophysical surveys provide support to development of hydrogeologic frameworks to be used in groundwater models for management purposes. As the AEM technology continues to be applied in this or other studies, consideration of the following approaches or procedures likely will prove useful. Planning a survey requires a good geologic model that includes known electrical stratigraphy. It also must consider environmental factors such as water quality, infrastructure, and demographics. It is important to match the airborne system to the target to be mapped. Shallow targets in electrically resistive lithology overlying electrically conductive lithology are best mapped by a wellcalibrated, frequency-domain AEM system. Deep targets and areas that have more conductive lithologies are best mapped with a time-domain (TDEM) AEM system. In other situations, an electromagnetic system may be not at all suitable, and a different geophysical method would be appropriate. All future projects will benefit from some type of forward modeling to make a proper method selection. Additionally, we suggest combining magnetic resonance sounding (Legchenko and others 2002), which is a direct measurement of free water content in the aquifer and can provide information about hydraulic conductivity, with AEM surveys, which map resistivity of the lithology, to create threedimensional maps of the aquifers.

One suggestion for further study is to provide intentional recharge to aquifer systems through the use of surface-water irrigation. Water from surface-water systems may be applied in a manner to increase the amount of water recharged to the groundwater system. This additional water may provide for irrigation offsets, increased base flow to streams, and even may provide a mechanism to supply surface water through groundwater recharge and subsequent withdrawal. In order to fully assess the feasibility of this approach, however, a robust groundwater model built on sound hydrogeologic frameworks must be created and used to analyze such changes to the hydrologic system.

Information gathered through this investigation may also be used to study changes in groundwater quality and how to best protect it from degradation. As with the suggestion for intentional recharge, understanding the hydrogeologic framework in great detail can assist managers in programmatic decisions. Understanding the hydrogeologic framework at the level of detail provided through this effort may allow management decisions to be made with greater confidence to provide for scenarios such as improved well-head protection areas, delineation of source and fate of contaminants along flow paths, and drawing of water-quality management areas with greater precision.

\section{Summary and Implication of Study Findings}

The airborne helicopter electromagnetic (HEM) system shows very good stability between flights and between 2008 and 2009 data-collection years. There was very little disagreement between the various datasets, and leveling the data was accomplished with little difficulty. Ground-based geophysical equipment, both TDEM and borehole geophysics, also were calibrated, and the results from those data were well-correlated with the AEM results.

Confidence in the ability of AEM to collect resistivity data that can undergo inversion into resistivity sections with depth and ultimate linkage to strengthed geologic interpretations has greatly improved during the course of this study. This confidence increased primarily by construction of the detailed resistivity plots, which compared very well with test-hole lithologic logs, geophysical borehole logs, surface geophysical soundings, and surficial outcrop maps. In turn, the use of the resistivity plots in development of the new base of aquifer (BOA) map has led to improved understanding of the hydrogeologic framework. Most importantly, the various datasets have a high degree of agreement when compared to each other. Completed resistivity sections and three-dimensional images were linked to the known geology, providing improved precision in developing the new hydrogeologic framework. The framework employed all available data sets, simultaneously providing information for interpretation within a geophysical modeling package. Quality control and assurance of the resulting data sets were accomplished by interactively checking the various testhole data, surface geology, and geophysical data sets. The output from that QC/QA work then was imported into GIS software, and contouring the elevations of the base of aquifer was completed.

The configuration of the BOA is a major controlling factor in direction and magnitude of groundwater flow. That configuration constrains tributaries to the North and South Platte Rivers as well as Lodgepole Creek. The original hydrogeologic framework for COHYST contained only test holes and geologic maps. Although those data indicated the presence of ancestral alluvial channels of the Tertiary Ogallala Group, Pliocene Broadwater Formation, and Quaternary alluvium, in areas where the airborne geophysical-survey data produced more precise location and elevation of such channels, a more detailed map was created. 
Currently, three active groundwater modeling projects cover the North Platte River valley. These are the COHYST model, the U.S. Geological Survey Northern High Plains Groundwater Availability model, and the North Platte Natural Resources District (NPNRD) Groundwater Management Model (S. M. Peterson, oral commun., 2011). The most detailed of these models is the NPNRD Groundwater Management Model (S. M. Peterson, oral commun., 2011); it was the first of these models to use the new AEM-derived interpretations of the hydrogeologic framework.

Understanding the complex groundwater-surface-water relationships of the North Platte River allows managers to better control the limited supplies of water for all uses, including protection of endangered species. The NPNRD Groundwater Management Model (S. M. Peterson, oral commun., 2011) is being built specifically to test a range of potential management scenarios aimed at balancing agricultural water supply and demand as well as surface-water and groundwater interactions, inflows, and outflows. Data provided by the AEM survey enabled considerable improvement in the understanding of the hydrogeologic framework of the North Platte River valley and were used to refine and thus improve groundwater models of the area. Initial results of simulations made with this model indicate (1) the creation of the refined hydrogeologic framework resulted in a redistribution of flow-path orientation (redefining the location of paleochannels), and (2) the NPNRD groundwater model represents hydrogeology at a level of accuracy not achievable using previous datasets. This study illustrates the manner in which a geophysical survey is driven by the need for a refined hydrogeological framework for a groundwater model.

The complexity of the new BOA provides a more accurate representation of hydrogeological conditions. This provides water-resource managers increased confidence in the data upon which their decisions are based. It also affects which management entity is responsible for management of the water supply. In Nebraska, groundwater management is provided by the natural resources districts (NRDs) for groundwater quantity, quality, and interaction with surface water; surface water in turn is managed separately by the Nebraska Department of Natural Resources (NDNR). Areas where the principal aquifer is hydrologically connected to streams are managed jointly by the NRD and the NDNR. In the above profile descriptions, the new BOA provides an example of how it can be used to make a determination of where water supplies can be managed by the NRDs, by NDNR, or jointly.

Questions to be answered with this work are related to groundwater-surface-water relationships and water supply, as well as water quality in critical reaches of the Platte River Basin. The State of Nebraska has designated substantial areas in each of the NRDs as "over appropriated" and "fully appropriated" for water supply. Effective management now and in the future will rest on thorough understanding and testing of management scenarios through groundwater modeling. The new base of aquifer (BOA) can be used to determine whether the principal aquifer is hydrologically connected to streams, and thus the appropriate agency or agencies can be selected for managing the water supply.

\section{Acknowledgments}

The authors thank Ronald Cacek, Manager, North Platte Natural Resources District (NPNRD), and Rod Horn, Manager, South Platte Natural Resources District (SPNRD), for coordination of financial and material support of the hydrogeophysical program.

\section{References Cited}

Auken, E., and Nebel, K., 2001, Getting started with SiTEM and SEMDI: Finlandsgade, Denmark, University of Aarhus, Dept. of Earth Sciences HydroGeophysics Group, 21 p.

Ball, L.B., Kress, W.H., Steele, G.V., Cannia, J.C., and Andersen, M.J., 2006, Determination of canal leakage potential using continuous resistivity profiling techniques, Interstate and Tri-State Canals, western Nebraska and eastern Wyoming - 2004: U.S. Geological Survey Scientific Investigations Report 2006-5032, 53 p. (Also available at http://pubs.usgs.gov/sir/2006/5032/.)

Barrash, W., 1986, Hydrostratigraphy and hydraulic behavior of fractured formation in Sidney Draw, Cheyenne County, Nebraska: Moscow, University of Idaho, Ph.D. dissertation, 205 p., 4 pls.

Bjorklund, L.J., 1957, Geology and ground-water resources of the lower Lodgepole Creek drainage basin, Nebraska, with a section on The chemical quality of the water, by E.R. Jochens: U.S. Geological Survey Water-Supply Paper 1410, 76 p., 4 pls.

Burton, B.L., Johnson, M.R., Vrabel, J., Imig, B.H., Payne, J.D., and Tompkins, R.E., 2009, Capacitively coupled resistivity survey of selected irrigation canals within the North Platte River valley, western Nebraska and eastern Wyoming, 2004 and 2007-2009: U.S. Geological Survey Scientific Investigations Report 2009-5194, 79 p. (Also available at http://pubs.usgs.gov/sir/2009/5194/.)

Cannia, J.C., Woodward, D., and Cast, L.C., 2006, Cooperative Hydrology Study [COHYST] hydrostratigraphic units and aquifer characterization report: Lincoln, Nebr., Nebraska Dept. of Natural Resources Cooperative Hydrology Study, 96 p. (Also available at http://cohyst.dnr.ne.gov/.)

Carney, C.P., 2008, Groundwater flow model of the central model unit of the Nebraska Cooperative Hydrology Study (COHYST) area: Lincoln, Nebr., Nebraska Department of Natural Resources, 87 p. (Also available at $h t t p: / /$ cohyst.dnr.ne.gov/adobe/dc012CMU_GFMR_081224.pdf.)

Christiansen, A.V., and Christensen, N.B., 2003, A quantitative appraisal of airborne and ground-based transient electromagnetic (TEM) measurements in Denmark: Geophysics, v. 68 , no. 2, p. $523-534$. 
Danielsen, J.E., Auken, E., Jørgensen, F., Søndergaard, V., and Sørensen, K.I., 2003, The application of the transient electromagnetic method in hydrogeophysical surveys: Journal of Applied Geophysics, v. 53, no. 4, p. 181-198.

Darton, N.H., 1903a, Geologic atlas of the United States, Scotts Bluff folio, Nebraska: U.S. Geological Survey Folio 88, 5 p.

Darton, N.H., 1903b, Preliminary report on the geology and water resources of Nebraska west of the one-hundred and third meridian: U.S. Geological Survey Professional Paper 17, 69 p.

Eberhart-Phillips, D., Stanley, W.D., Rodriguez, B.D., and Lutter, W.J., 1995, Surface seismic and electrical methods to detect fluids related to faulting: Journal of Geophysical Research, v. 100, no. B7, p. 12919-12936.

Esri, 2011, ArcGIS - Mapping and spatial analysis for understanding our world: Redlands, Cal., Esri. Software available at http://www.esri.com/software/arcgis/. (Accessed December 4, 2011).

Farquharson, C.G., Oldenberg, D.W., and Routh, P.S., 2003, Simultaneous one-dimensional inversion of loop-loop electromagnetic data for magnetic susceptibility and electrical conductivity: Geophysics, v. 68, p. 1857-1869.

Fitterman, D.V., 1988, Examples of transient soundings for ground-water exploration in sedimentary aquifers: Groundwater, v. 25, no. 6, p. 685-692.

Fitterman, D.V., 1989, Detectability levels for central induction transient soundings: Geophysics, v. 54, p. 127-129.

Fitterman, D.V., and Labson, V.F., 2005, Electromagnetic induction methods for environmental problems, in Butler, D.K., ed., Near-Surface Geophysics - SEG Investigations in Geophysics Series: Tulsa, Okla., Society of Exploration Geophysicists, no. 13, p. 301-351.

Fitterman, D.V., and Stewart, M.T., 1986, Transient electromagnetic sounding for groundwater: Geophysics, v. 51, p. 995-1005.

Goodwin, R.G., and Diffendal, R.F., Jr., 1987, Paleohydrology of some Ogallala (Neogene) streams in the southern Panhandle of Nebraska: Society of Economic Paleontologists and Mineralogists Special Publication no. 39, p. 149-157.

Keller, G.V., 1987, Rock and mineral properties, in Nabighian, M.N., ed., Electromagnetic Methods in Applied Geophysics Theory: Tulsa, Okla., Society of Exploration Geophysicists, v. 1, p. $13-51$.

Keller, G.V., 1989, Electrical properties, in Carmichael, R.S., ed., Practical Handbook of Physical Properties of Rocks and Minerals: Boca Raton, Fla., CRC Press, p. 359-427.
Legchenko, A., Baltassat, J.M., Beauce, A., and Benard, J., 2002, Nuclear magnetic resonance as a geophysical tool for hydrologists: Journal of Applied Geophysics; v. 50, p. $21-46$.

Lowry, M.E., 1966, The White River Formation as an aquifer in southeastern Wyoming and adjacent parts of Nebraska and Colorado: U.S. Geological Survey Professional Paper 550-D, p. 217-222.

Luckey, R.R., and Cannia, J.C., 2006, Cooperative Hydrology Study groundwater flow model of the western model unit of the Nebraska Cooperative Hydrology Study (COHYST) area: Lincoln, Nebr., Nebraska Department of Natural Resources, 63 p. (Also available at http://cohyst.dnr.ne.gov/ adobeldc012WMU_GFMR_060519.pdf.

Lugn, A.L., 1935, The Pleistocene geology of Nebraska: Nebraska Geological Survey Bulletin, v. 10, 223 p.

Meinzer, O.E., 1923, The occurrence of ground water in the United States, with a discussion of principles: U.S. Geological Survey Water-Supply Paper 489, 321 p.

Nabighian, M.N., and Macnae, J.C., 1991, Time-domain electromagnetic prospecting methods, in Nabighian, M.N., ed., Electromagnetic Methods in Applied Geophysics Theory: Tulsa, Okla., Society of Exploration Geophysicists, v. 2 , p. $427-520$.

Nelson, P.H., and Anderson, L.A., 1992, Physical properties of ash flow tuff from Yucca Mountain, Nevada: Journal of Geophysical Research, v. 97, no. B5, p. 6823-6841.

Oldenburg, D.W., and Li, Y., 1999, Estimating depth of investigation in DC resistivity and IP surveys: Geophysics, v. 64, p. 403-416.

Palacky, G.J., 1987, Resistivity characteristics of geologic targets, in Nabighian, M.N., ed., Electromagnetic Methods in Applied Geophysics Theory: Tulsa, Okla., Society of Exploration Geophysicists, v. 1, p. 53-129.

Peterson, S.P., 2007, Groundwater flow model of the eastern model unit of the Nebraska Cooperative Hydrology Study (COHYST) area: Lincoln, Nebr. Nebraska Department of Natural Resources, 80 p. (Also available at http:// cohyst.dnr.ne.gov/adobe/dc012EMU_GFMR_090507.pdf.)

Platte River Recovery and Implementation Plan, 2011, accessed July 2011, at http://www.platteriverprogram.org/ Pages/default.aspx.

Qi, S.L., 2010, Digital map of the aquifer boundary of the High Plains aquifer in parts of Colorado, Kansas, Nebraska, New Mexico, Oklahoma, South Dakota, Texas, and Wyoming: U.S. Geological Survey Data Series 543. (Also available at http://pubs.usgs.gov/ds/543/.) 
Qi, S.L., and Christenson, S., 2010, Assessing groundwater availability in the High Plains aquifer in parts of Colorado, Kansas, Nebraska, New Mexico, Oklahoma, South Dakota, Texas, and Wyoming: U.S. Geological Survey Fact Sheet 2010-3008 (Revised March 2010), 4 p. (Also available at $h t t p: / / p u b s . u s g s . g o v / f s / 2010 / 3008 /$.)

Sibray, S.S., and Zhang, Y.K., 1994, Three-dimensional modeling of hydraulic behavior of a highly conductive secondary permeability zone in the Brule Formation, in Warner, J.W., and van der Heijde, Paul, eds., [The] 1994 Groundwater Modeling Conference, Fort Collins, Colorado, August 10-12, 1994, Proceedings: Fort Collins, Colo., Colorado State University, p. 445-452.

Smith, B.D., Abraham, J.D., Cannia, J.C., and Hill, P., 2009, Helicopter electromagnetic and magnetic geophysical survey data for portions of the North Platte River and Lodgepole Creek, Nebraska, June 2008: U.S. Geological Survey Open-File Report 2009-1110, 27 p. (Also available at $h t t p: / / p u b s . u s g s . g o v / o f / 2009 / 1110 /$.)

Smith, B.D., Abraham, J.D., Cannia, J.C., Minsley, B.J., Deszcz-Pan, M., and Ball, L.B., 2010, Helicopter electromagnetic and magnetic geophysical survey data, portions of the North Platte and South Platte Natural Resources Districts, western Nebraska, May 2009: U.S. Geological Survey Open-File Report 2010-1259, 33 p. (Also available at http://pubs.usgs.gov/of/2010/1259/.)

Smith, B.D., Grauch, V.J.S., McCafferty, A.E., Smith, D.V., Rodriguez, B.R., Pool, D.R., Deszcz-Pan, M., and Labson, V.F., 2007, Airborne electromagnetic and magnetic surveys for ground-water resources-A decade of study by the U.S. Geological Survey, in Milkereit, B., ed., Exploration '07-Exploration in the new millennium, 5th, Toronto, Canada, September 9-12, 2007, Proceedings: Toronto, Decennial International Conference on Mineral Exploration, p. $895-899$.

Smith, F.A., 1969, Preliminary groundwater reportAvailability of groundwater for irrigation in Cheyenne County, Nebraska: Lincoln, Nebr., Nebraska Water Survey, Conservation and Survey Division, University of NebraskaLincoln, 89 p.

Smith, F.A., and Souders, V.L., 1971, Occurrence of groundwater in Kimball County, Nebraska: Lincoln, Nebr., Nebraska Water Survey, Conservation and Survey Division, University of Nebraska-Lincoln Water Supply Paper no. 29, $135 \mathrm{p}$.

Smith, F.A., and Souders, V.L., 1975, Groundwater geology of Banner County, Nebraska: Lincoln, Nebr., Nebraska Water Survey, Conservation and Survey Division, University of Nebraska-Lincoln Water Supply Paper no. 39, 96 p.
Souders, V.L., 1986, Geologic sections, ground-water maps, and logs of test-holes, Morrill County, Nebraska: Lincoln, Nebr., Nebraska Water Survey, Conservation and Survey Division, University of Nebraska-Lincoln Open-File Report, 90 p.

South Platte Natural Resources District, 2008, Integrated management plan: Lincoln, Nebr., Nebraska Department of Natural Resources, South Platte Natural Resources District, $63 \mathrm{p}$.

Steele, G.V., Sibray, S.S., and Quandt, K.A., 2007, Evaluation of ground water near Sidney, western Nebraska, 2004-05: U.S. Geological Survey Scientific Investigations Report 2007-5086, 54 p. (Also available at $h t t p: / / p u b s . u s g s . g o v /$ sir/2007/5086/.)

Swinehart, J.B., Souders, V.L., DeGraw, H.M., and Diffendal, R.F., Jr., 1985, Cenozoic paleogeography of western Nebraska, in Flores, R.M., and Kaplin, S.S., eds., Cenozoic Paleogeography of the west-central United States: Denver, Colo., Rocky Mountain Section, Society of Economic Paleontology and Mineralogy, p. 209-229.

Terry, D.O., 1998, Lithostratigraphic revision and correlation of the lower part of the White River Group-South Dakota to Nebraska: Boulder, Colo., Geological Society of America Special Paper, no. 325, p. 15-37.

Tychsen, P.C., 1954, A sedimentation study of the Brule Formation in northwest Nebraska: Lincoln, Nebr., University of Nebraska, Ph.D. dissertation, 189 p., 25 pls.

University of Nebraska-Lincoln, 2011, Nebraska statewide test-hole database retrieval system: Lincoln, Nebr., University of Nebraska-Lincoln School of Natural Resources/Conservation and Survey Division, accessed July 2011, at http://snr.unl.edu/data/geographygis/ NebraskaTestHole/NebraskaTestHoleIntro.asp.

University of Nebraska-Lincoln, 2010, Historical climate data summaries: Lincoln, Nebr., University of Nebraska-Lincoln High Plains Regional Climate Center, accessed July 22, 2011, at http://www.hprcc.unl.edu/cgi-bin/cli_perl_lib/ cliMAIN.pl?ne7665.

Verstraeten, I.M., Sibray, S.S., Cannia, J.C., and Tanner, D.Q., 1995, Reconnaissance of ground-water quality in the North Platte Natural Resources District, western Nebraska, June-July 1991: U.S. Geological Survey Water-Resources Investigations Report 94-4057, 114 p.

Wenzel, L.K., Cady, R.C., and Waite, H.A., 1946, Geology and ground-water resources of Scotts Bluff County, Nebraska: U.S. Geological Survey Water-Supply Paper 943, $150 \mathrm{p}$.

Worboys, M.F., 1995, GIS-A computing perspective: London, Taylor and Francis, 376 p. 
Appendixes 


\section{Appendix 1. Results of Time-domain Electromagnetic Soundings, Nebraska}

Results of the time-domain electromagnetic soundings in the South Platte Natural Resources District (SPNRD), Nebr. At each station, the right panel shows the best-fit minimum-layer (red) and smooth (blue) inverse models. The left panel shows the forward response (straight lines) for both the minimum-layer and smooth models overlaid on the measured data. [Abbreviations and correlations: SP, South Platte; NP, North Platte; table A1, (A) station SP0, (B) station SP1, (C) station SP2, (D) station SP3, (E) station SP4, (F) station SP5, (G) station SP6, (H) SP7, (I) station SP8; see table A1 below] and the North Platte Natural Resources District (NPNRD), Nebr. [(J) station NP1, (K) station NP2, (L) station NP3, (M) station NP4, (N) station NP5, (O) station NP6, (P) station NP7.]

Table A1. Location of time-domain electromagnetic soundings. Easting and Northing are in Universal Transverse Mercator (UTM) zone 13N. Elevation is relative to National Geodetic Vertical Datum of 1929 (NGVD29).

\begin{tabular}{ccccc}
\hline Natural Resources District & Station & $\begin{array}{c}\text { Easting } \\
\text { (meters) }\end{array}$ & $\begin{array}{c}\text { Northing } \\
\text { (meters) }\end{array}$ & $\begin{array}{c}\text { Elevation } \\
\text { (meters) }\end{array}$ \\
\hline North Platte & NP_1 & 587145.312 & 4651326.685 & 1211.30 \\
North Platte & NP_2 & 586324.931 & 4654694.720 & 1202.10 \\
North Platte & NP_3 & 586764.049 & 4657633.988 & 1208.42 \\
North Platte & NP_4 & 587927.706 & 4645062.159 & 1118.93 \\
North Platte & NP_5 & 675710.465 & 4632429.385 & 1134.40 \\
North Platte & NP_6 & 676380.069 & 4618278.372 & 1120.55 \\
North Platte & NP_7 & 677184.461 & 4594684.441 & 1100.18 \\
South Platte & SP_0 & 588935.893 & 4574616.908 & 1433.65 \\
South Platte & SP_1 & 626260.740 & 4567726.021 & 1287.30 \\
South Platte & SP_2 & 629671.043 & 4577021.378 & 1240.98 \\
South Platte & SP_3 & 636891.392 & 4582402.762 & 1235.75 \\
South Platte & SP_4 & 643870.014 & 4566314.639 & 1167.19 \\
South Platte & SP_5 & 665003.898 & 4585325.690 & 1151.13 \\
South Platte & SP_6 & 6667379.213 & 4580002.611 & 1164.48 \\
South Platte & SP_7 & 667200.664 & 4575217.453 & 1073.79 \\
South Platte & SP_8 & 710661.609 & 4547473.726 & \\
\hline
\end{tabular}




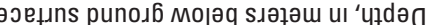

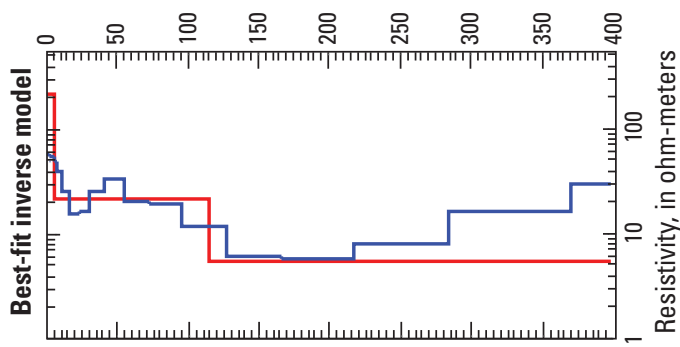

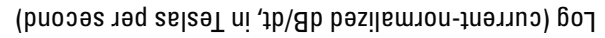

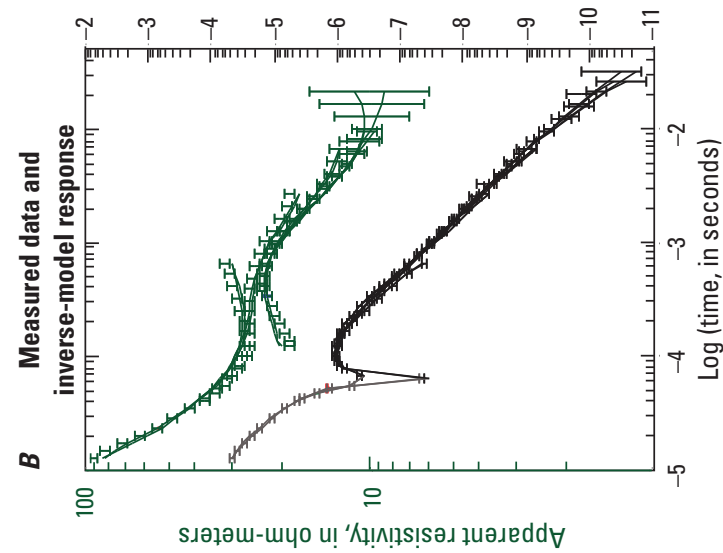

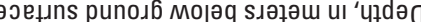
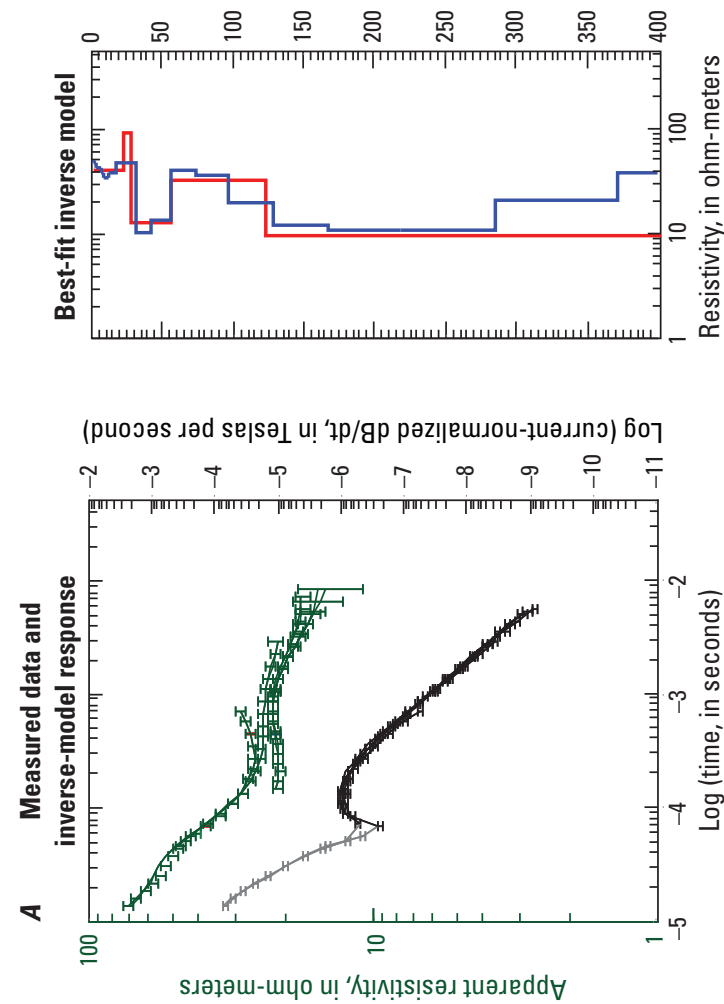

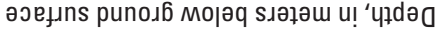

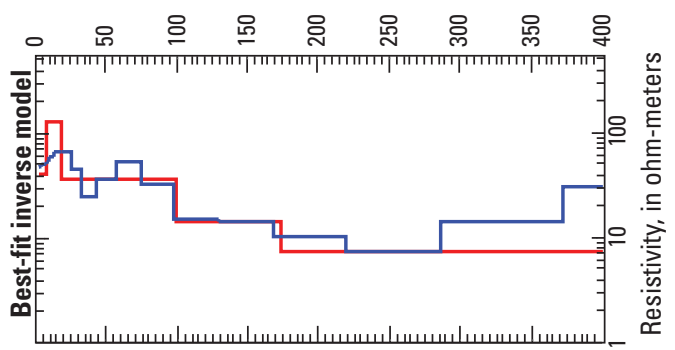

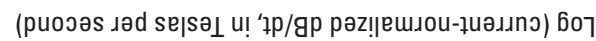

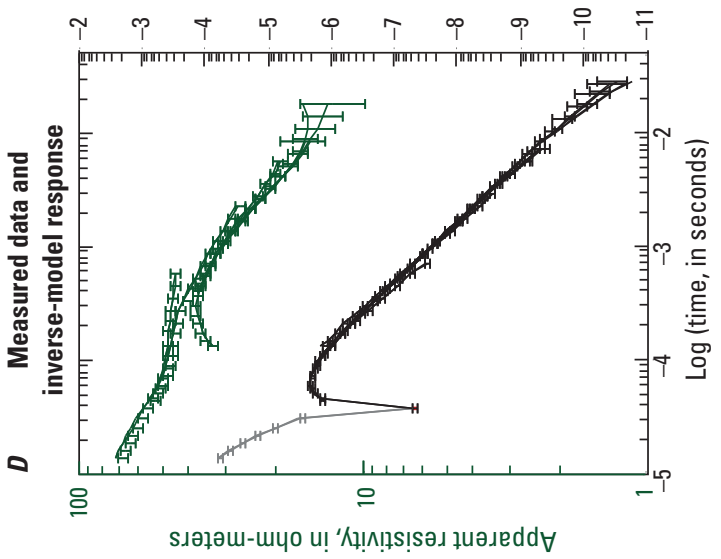

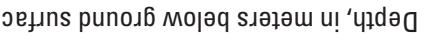
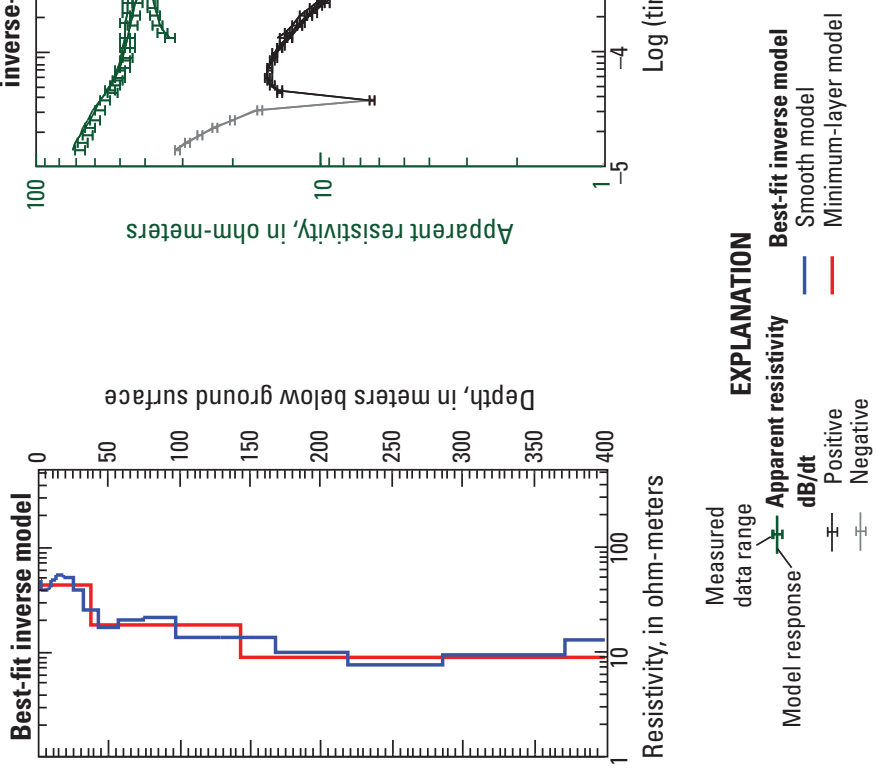

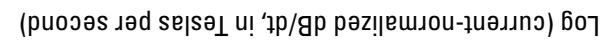

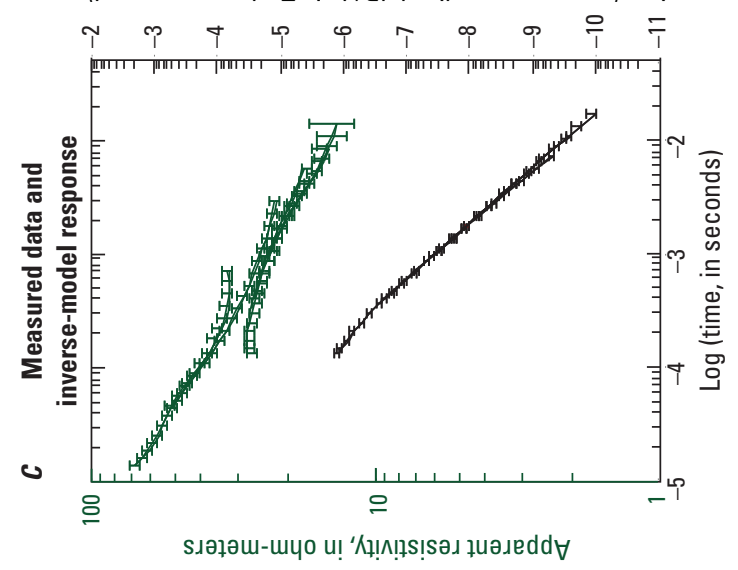



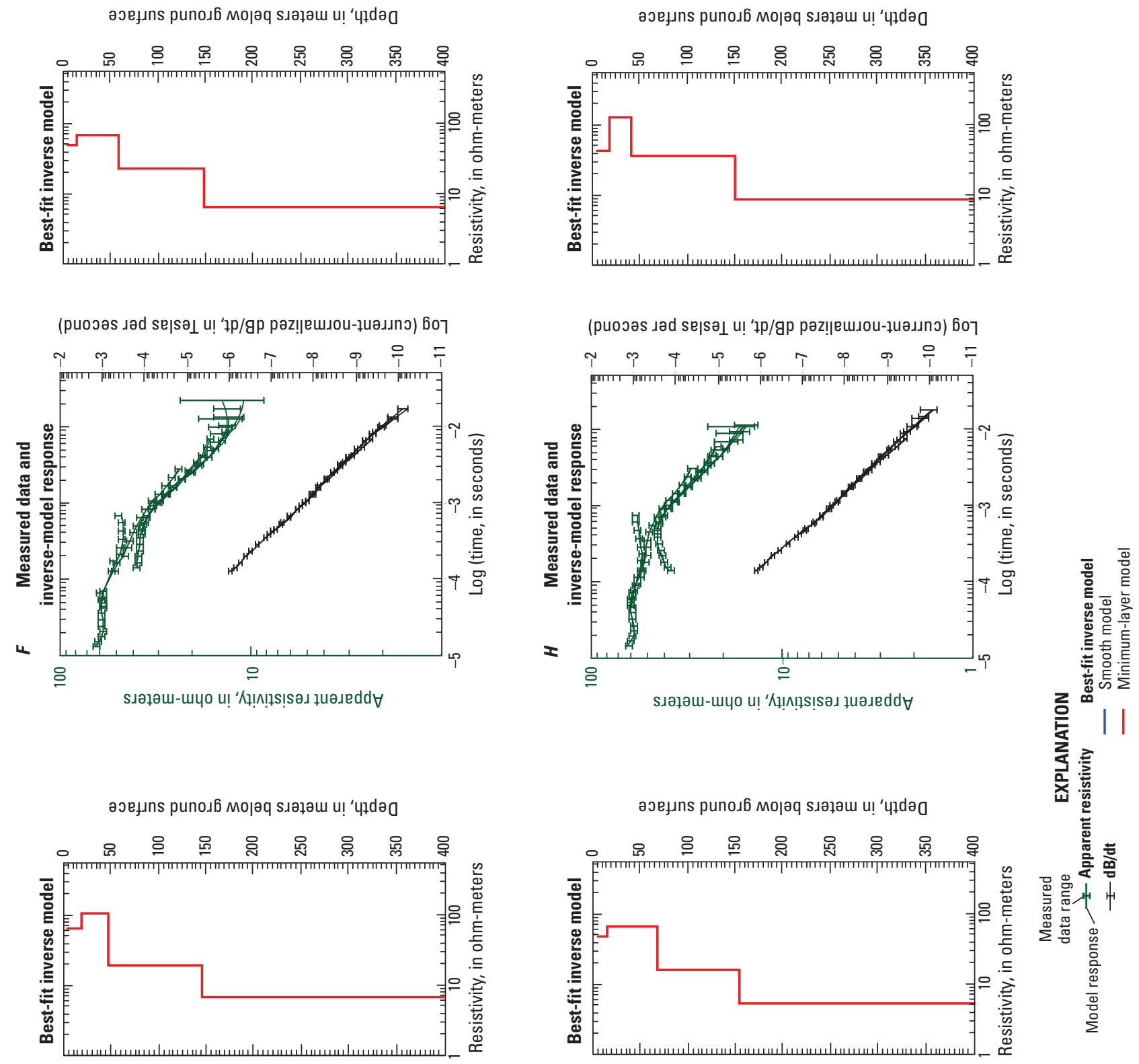

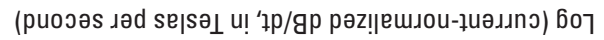
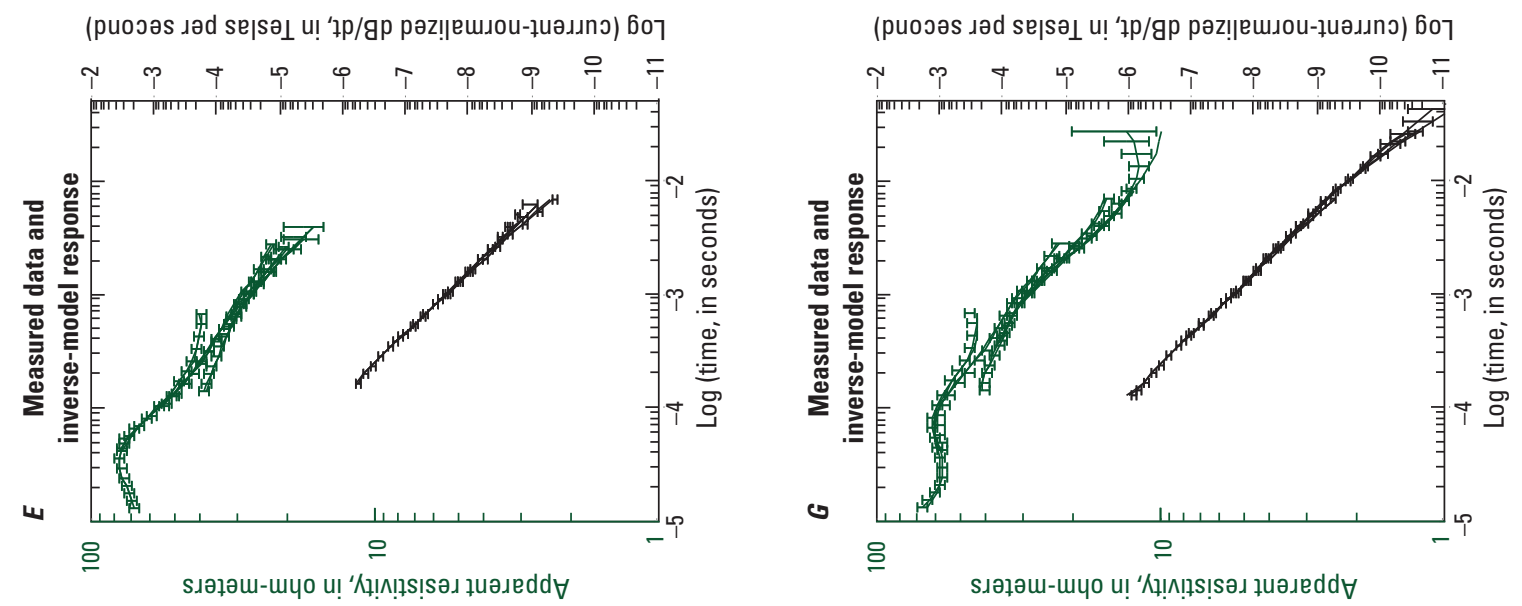

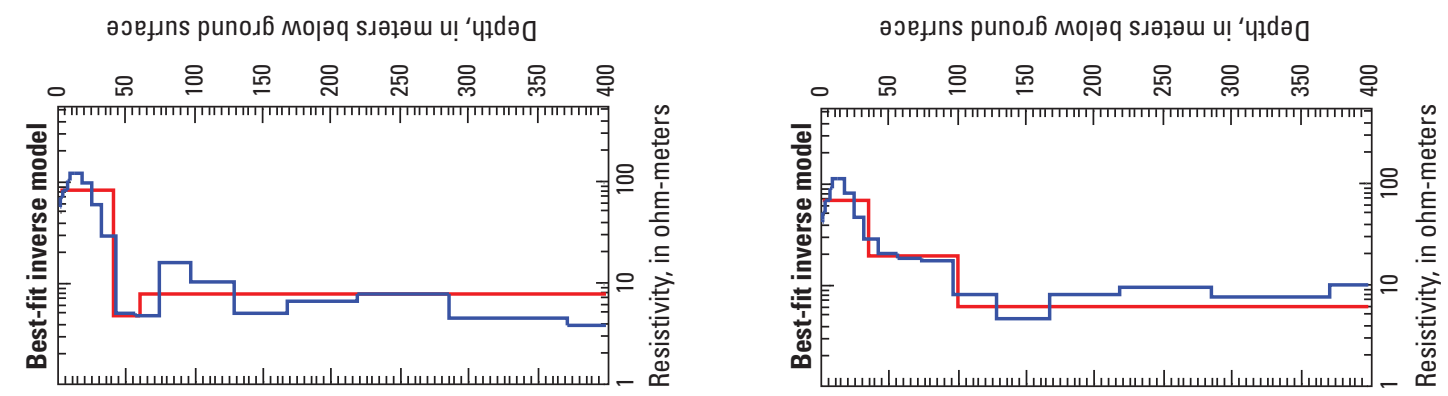

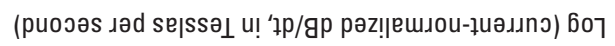

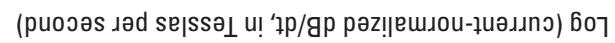
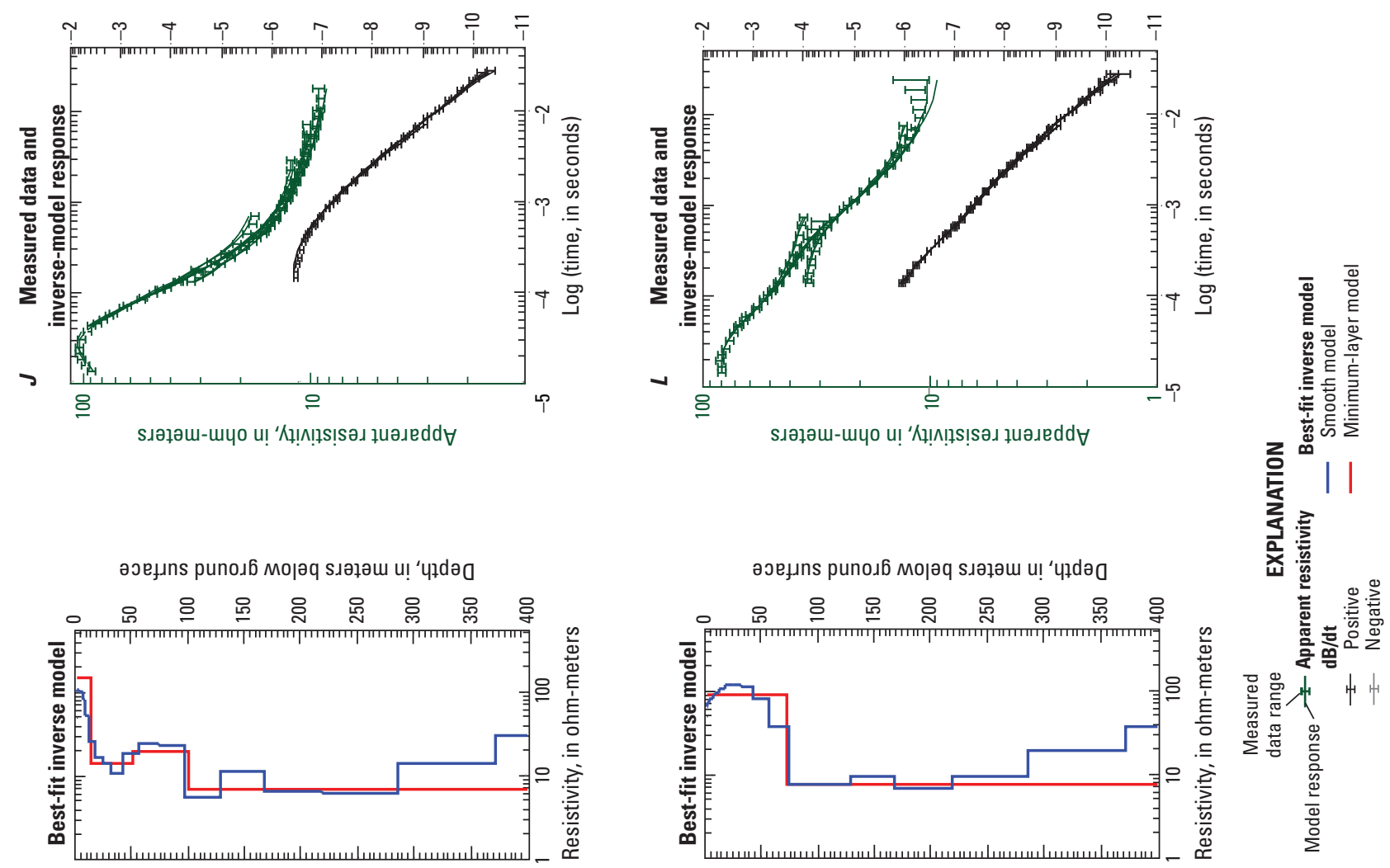

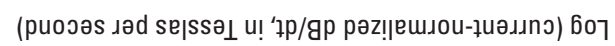
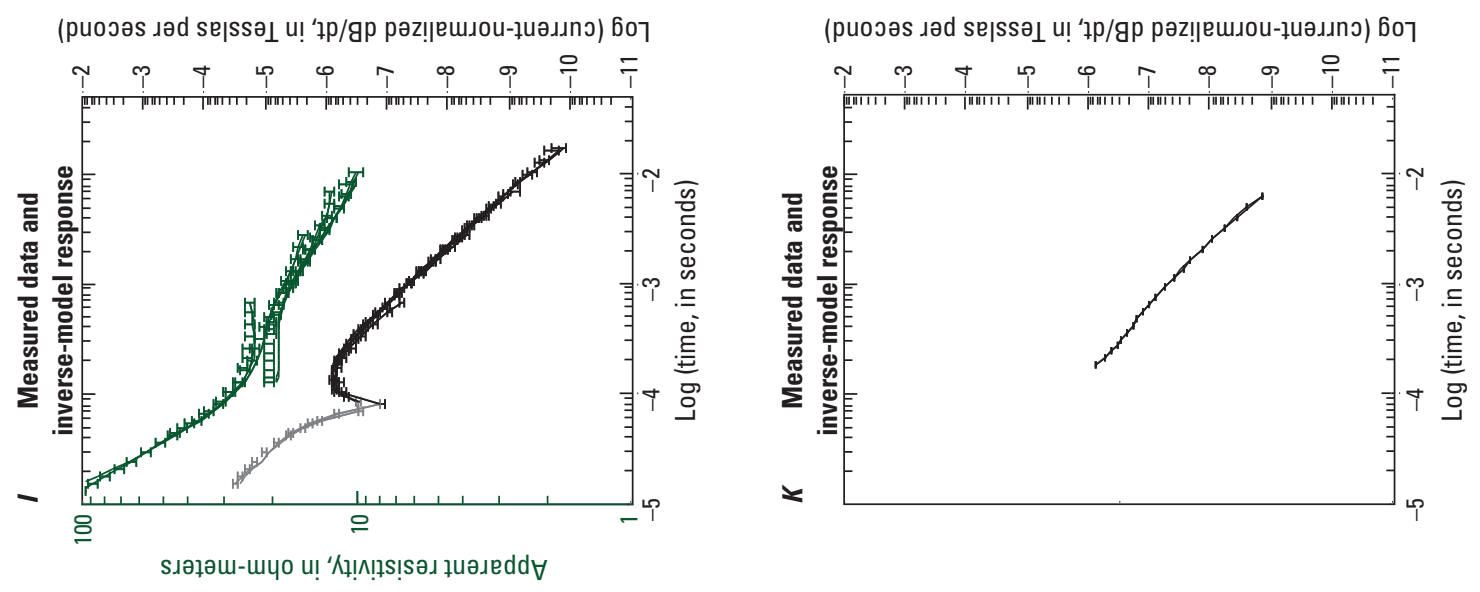

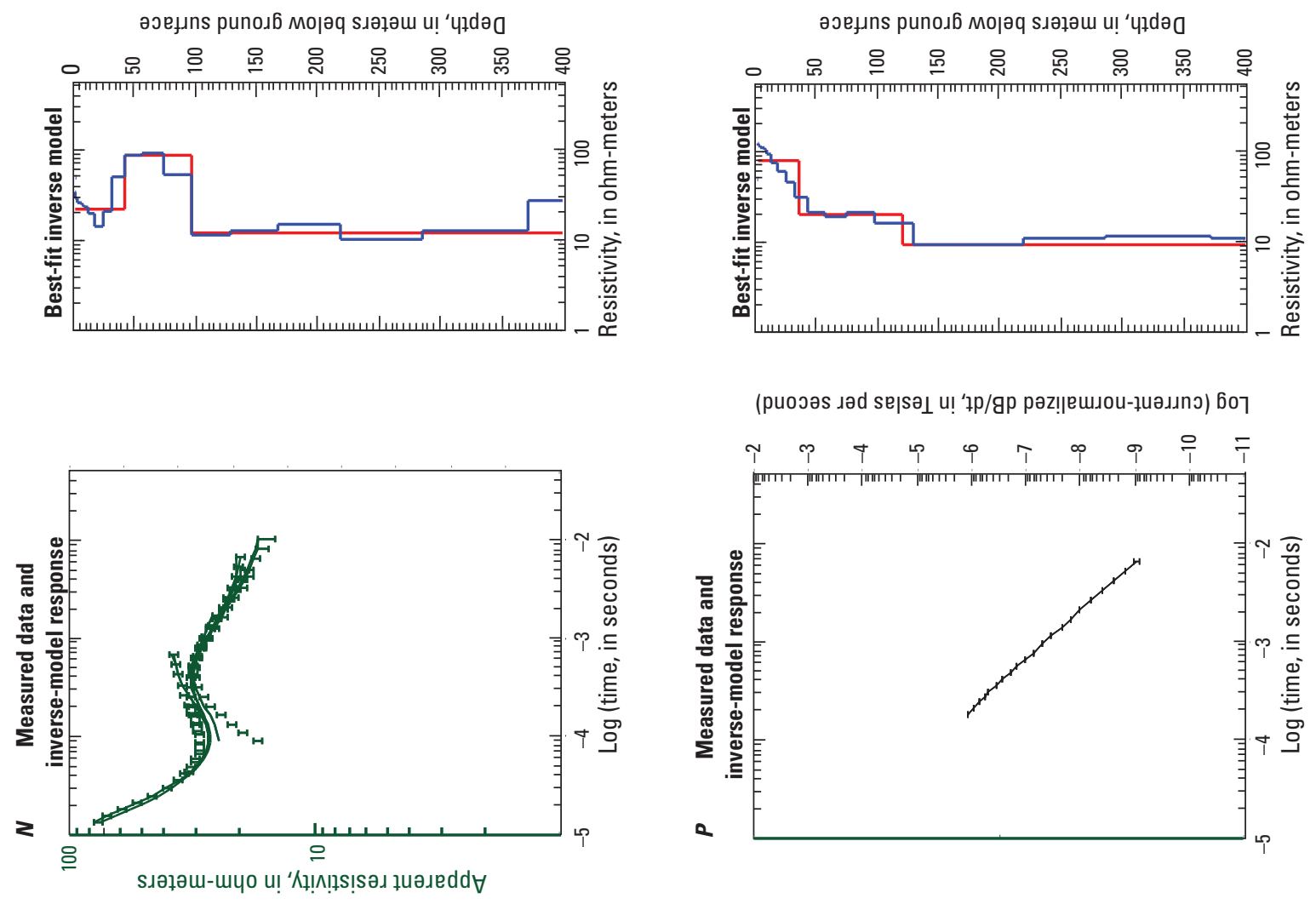

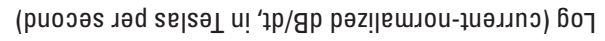

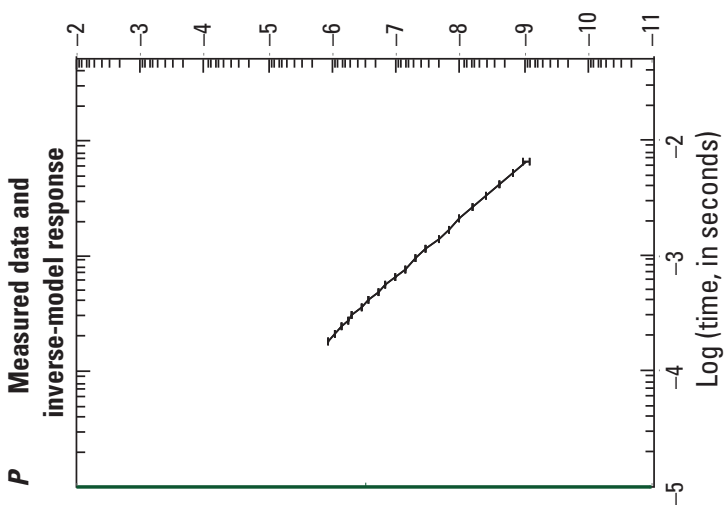

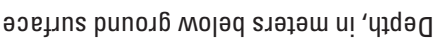
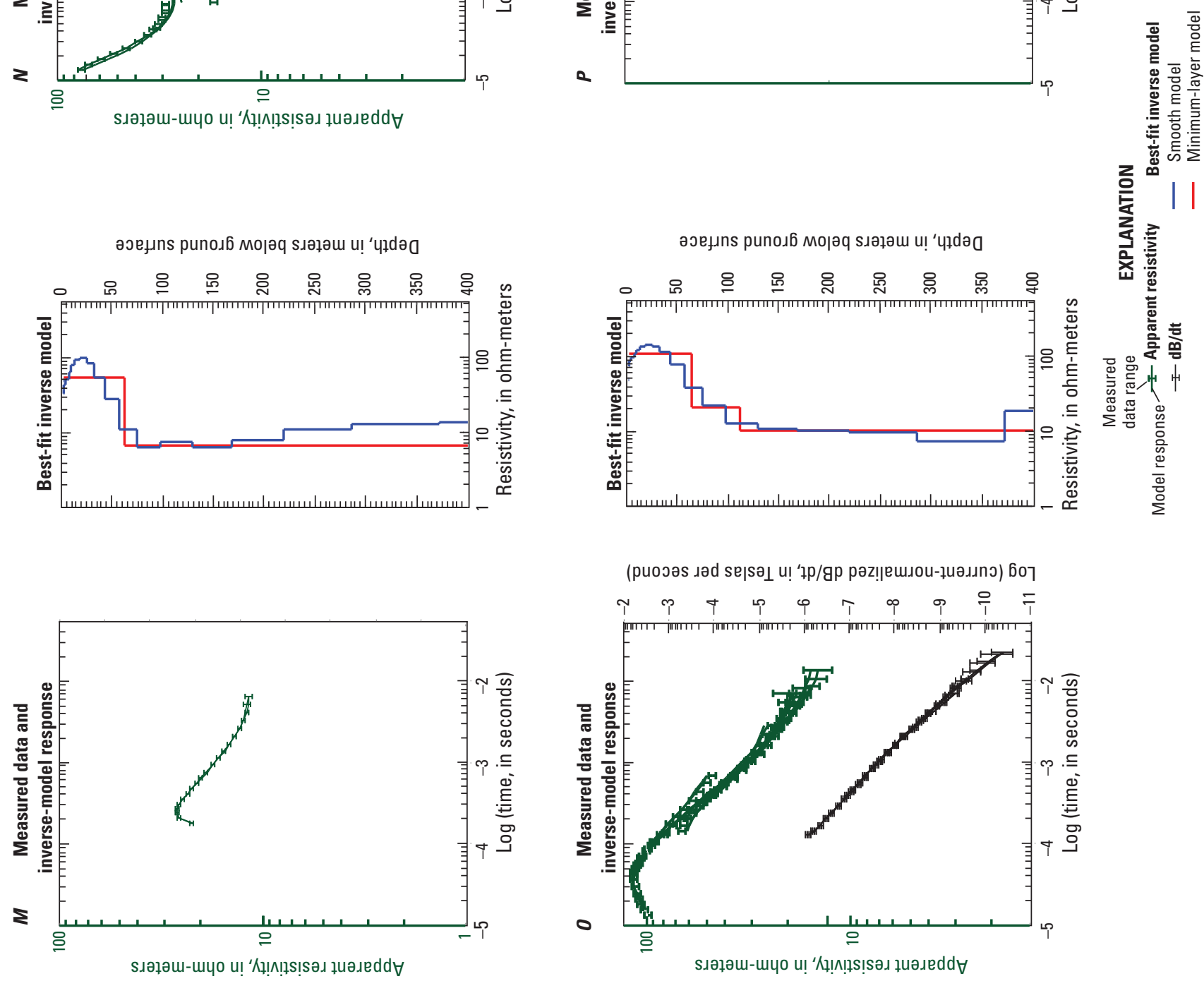


\section{Appendix 2. Interpretation-Picks Databases Explanation}

\section{Digital Data}

Digital base of aquifer "pick" data are provided in an ASCII-formatted, comma-separated file titled western_NE_AEM_picks.txt. The data headings are as follows:

- Line: [flight]line name;

- Year: year of acquisition of airborne electromagnetic data;

- $X$ and $Y$ : easting and northing coordinates of base of aquifer "pick" in North American Datum of 1983 (NAD83), Universal Transverse Mercator (UTM) zone 13N, in meters;

- Elevation (DEM): elevation from the digital elevation model used in the study relative to the National Geodetic Vertical Datum of 1929 (NGVD29), in meters;

- Pick_Elevation: elevation of base of aquifer "pick" in NGVD29, in meters;

- Pick-DOI: depth (positive downward) of the depth of investigation of the airborne electromagnetic soundings, in meters; and

- Confidence_metric: confidence metric on the "pick" confidence value, between 1 and -1, for each location, with 1 being the highest confidence (picked horizon is well within the depth of investigation) and -1 being the lowest confidence (picked horizon is well below the depth of investigation). 


\section{Appendix 3. Contour Files}

\section{GIS Data}

The GIS data are given as a compressed file described in the ReadME.txt file and provided in separate directories within the file by NRD, NPNRD and SPNRD. These folders contain Esri grids, grid export to ASCII text files, Esri shapefiles, and METADATA subdirectories related to the airborne electromagnetic base of aquifer (AEM-BOA) revisions. These data were used in revising the BOA contours described in the report in the section "Redefining the base of aquifer contours." Metadata are provided in a separate subdirectory (METADATA) within the South Platte Natural Resources District (SPNRD) and the North Platte Natural Resources District (NPNRD) folders for each dataset. All data are in Universal Transverse Mercator (UTM) Zone 13 North, in meters, with horizontal datum the North American datum of 1983 (NAD83), vertical datum the National Geodetic Vertical Datum of 1929 (NGVD29), and z units, in feet. The data provided are listed in the table below for reference.

Table 3A. Correlations and descriptions of GIS data files supporting airborne electromagnetic base of aquifer revisions, Nebraska.

[Abbreviations: NPNRD, North Platte Natural Resources District, Nebr.; SPNRD, South Platte Natural Resources District, Nebr.; AEM, airborne electromagnetic (geophysical); COHYST, Cooperative Hydrology Study; DEM, digital elevation model.]

\begin{tabular}{|c|c|c|}
\hline Folder & Name & Description \\
\hline NPNRD & $\begin{array}{l}\text { METADATA } \\
\text { npnrd_aem_aqbase_contour } \\
\text { npnrd_all_aqbase_control_points } \\
\text { np_cohyst90 } \\
\text { np_cohyst90.asc } \\
\text { npnrd_aqbase } \\
\text { npnrd_aqbase.asc } \\
\text { npnrddem90 } \\
\text { npnrddem90.asc } \\
\text { npnrdthick } \\
\text { npnrdthick.asc }\end{array}$ & $\begin{array}{l}\text { Subdirectory of all metadata text files } \\
\text { Shapefile of AEM base of aquifer with xml-format metadata } \\
\text { Shapefile of all control points for base of aquifer contours with xml-format metadata } \\
\text { COHYST 90-meter base of aquifer grid } \\
\text { COHYST 90-meter base of aquifer grid exported to ascii text file } \\
\text { AEM 90-meter base of aquifer grid } \\
\text { AEM 90-meter base of aquifer grid exported to ascii text file } \\
\text { 90-meter DEM } \\
\text { 90-meter DEM exported to ascii text file } \\
\text { Estimated aquifer thickness in feet (NPNRDDEM90 - NPNRD_AQBASE) } \\
\text { Estimated aquifer thickness in feet (NPNRDDEM90 - NPNRD_AQBASE) exported } \\
\text { to ascii text file }\end{array}$ \\
\hline SPNRD & $\begin{array}{l}\text { METADATA } \\
\text { spnrd_aem_aqbase_contour } \\
\text { spnrd_all_aqbase_contour } \\
\text { sp_cohyst } 90 \\
\text { sp_cohyst90.asc } \\
\text { spnrd_aqbase } \\
\text { spnrd_aqbase.asc } \\
\text { spnrddem90 } \\
\text { spnrddem90.asc } \\
\text { spnrdthick } \\
\text { spnrdthick.asc }\end{array}$ & $\begin{array}{l}\text { Subdirectory of all metadata text files } \\
\text { Shapefile of AEM base of aquifer with xml-format metadata } \\
\text { Shapefile of all control points for base of aquifer contours with xml-format metadata } \\
\text { COHYST 90-meter base of aquifer grid } \\
\text { COHYST 90-meter base of aquifer grid exported to ascii text file } \\
\text { AEM 90-meter base of aquifer grid } \\
\text { AEM 90-meter base of aquifer grid exported to ascii text file } \\
\text { 90-meter DEM } \\
\text { 90-meter DEM exported to ascii text file } \\
\text { Estimated aquifer thickness in feet (NPNRDDEM90 - NPNRD_AQBASE) } \\
\text { Estimated aquifer thickness in feet (NPNRDDEM90 - NPNRD_AQBASE) exported } \\
\text { to ascii text file }\end{array}$ \\
\hline
\end{tabular}

Publishing support provided by:

Denver Publishing Service Center, Denver, Colorado

For more information concerning this publication, contact:

Center Director, USGS Crustal Geophysics and Geochemistry Science Center

Box 25046, Mail Stop 964

Denver, CO 80225

(303) 236-1312

Or visit the Crustal Geophysics and Geochemistry Science Center Web site at: http://crustal.usgs.gov/

This publication is available online at:

http://pubs.usgs.gov/sir/2011/5219/ 
올 